\title{
Warranties and Disclaimers in the Electronic Age
}

\author{
Robert A. Hillman* \& Ibrahim Barakat**
}

11 YALE J.L. \& TECH. 1 (2009)

\begin{abstract}
This article reports on software-licensor express warranty and disclaimer practices on the Internet. Our data show that virtually all of the websites and End User License Agreements (EULAs) we sampled include express warranties on the website and disclaimers of the warranties in the EULAs that may erase all or much of the quality protection. Next, the article reviews the reasons why consumers generally do not read their e-standard forms despite the prevalence of disclaimers and other adverse terms. We then argue that ecommerce exacerbates the problem of warranties and disclaimers and that lawmakers should address this issue. We contend that improved disclosure of disclaimers, including making them easily accessible on a website prior to any particular transaction and possibly even the subject of a pop-up window during a transaction, is the best of various imperfect solutions to the problem. Disclosure is inexpensive and, at minimum, creates the potential for more legitimate consumer assent to e-standard forms, including assent to disclaimers of warranty. Even if in the short term consumers do not read their forms, perhaps consumers will eventually learn of misleading warranties and disclaimers because the Internet creates communication possibilities and research tools unavailable to disgruntled purchasers in the paper world. The prospect of the word getting out that a licensor does not intend to stand behind its promises and representations may be sufficient to curtail the practice of misleading warranties and disclaimers.
\end{abstract}

\footnotetext{
* Edwin H. Woodruff Professor of Law, Cornell Law School. The author is Reporter, Principles of the Law of Software Contracts, American Law Institute. All ideas expressed herein are the authors' and not those of the American Law Institute. We thank Mark Grube for able research assistance and the faculty of Boston University Law School for very helpful comments at a workshop presentation.
}

**Associate, White and Case, L.L.P.; J.D. 2008, Cornell Law School. 
TABLE OF CONTENTS

Introduction ....................................................... 2

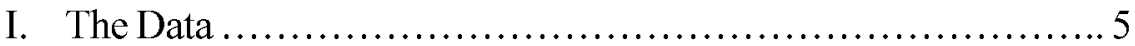

II. The e-Standard Form Environment ......................... 12

III. The Parol Evidence Rule in the Electronic Age ............. 17

IV. Enforcement of e-Disclaimers ............................. 22

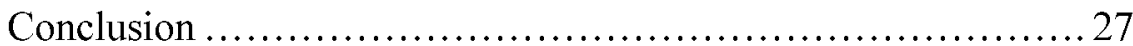

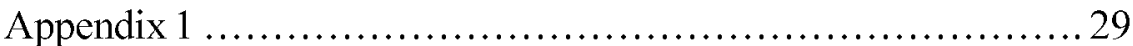

\section{INTRODUCTION}

A software licensor expressly warrants the quality of its software on its website. A consumer reads the warranty and decides to acquire the software. ${ }^{1}$ The consumer has no opportunity to inspect or test the software and therefore relies on the licensor's quality representations. For a host of reasons, both rational and irrational, the consumer fails to read the electronic standard form record (e-standard form) that governs the transaction, ${ }^{2}$ no less negotiate with anyone, before clicking "I agree" to the license. ${ }^{3}$ The e-standard form includes a disclaimer (e-disclaimer) of all express (and implied) warranties and a full integration clause. ${ }^{4}$ If the consumer attempts to avail himself of an express warranty when something goes wrong with the product, the licensor can point to the e-disclaimer and integration clauses and claim that evidence of the express warranty is inadmissible under contract law's parol evidence rule. Even if the evidence is admissible, the licensor can claim that the e-disclaimer supersedes any quality representations or promises.

Lawmakers should focus on this scenario because this manner of presenting express warranties and disclaimers online is remarkably widespread and potentially problematic. Part I of this article presents empirical evidence of just how prominent the strategy is. In a sample of fifty-four software titles culled from the top one hundred bestselling software products in which the licensor made its End User

${ }^{1}$ We focus on consumer transactions here, but recognize that the analysis could extend to small-business end users of software. See AMERICAN LAW INSTITUTE, PRINCIPLES OF THE LAW OF SOFTWARE CONTRACTS $§ 2.02$, Tentative Draft No. 1 (2008) [hereinafter ALI PRINCIPLES] (defining and explaining standard-form transfers of generally available software).

2 The standard form record is often called an End User License Agreement (EULA).

3 See generally Robert A. Hillman \& Jeffrey Rachlinski, Standard-Form Contracting in the Electronic Age, 77 N.Y.U. L. REV. 429 (2002).

4 A full integration clause states that the parties intend the record to be the complete and exclusive agreement between them on the subject matter. 
License Agreement (EULA) available on its website without a purchase, fifty-three contain express warranties on the website and edisclaimers in the EULAs that may erase all or much of this quality protection. $^{5}$ Of course, the problem of express warranties and disclaimers is not limited to e-commerce and is, in fact, common in the paper world too. But the online world magnifies the problem and presents new challenges for contract law. In this article, we analyze if and when express warranties on a licensor's website should trump e-disclaimers of those express warranties in the EULAs.

An important goal of contract law is to enforce a party's manifestation of assent to a contract made with full access to all pertinent information and with time to contemplate the terms. In so doing, contract law facilitates exchange and encourages reliance on contracts, which in turn maximizes resources and supports individual autonomy. Contract law's parol evidence rule bars assertions of agreements, promises, or representations inconsistent with a record the parties intended to be complete on the subject matter. ${ }^{6}$ In theory, this rule advances contract law's goals by weeding out fraudulent or other false assertions of prior inconsistent terms. But the problem of standard-form disclaimers in the online environment is not the potential for consumer fraud because the parties should rarely have occasion to dispute what a licensor's website says. ${ }^{7}$ The problem is that a consumer may be unfairly surprised to learn that the licensor does not intend to stand behind its express promises and representations. We argue that enforcement of warranties in this context should not depend on the parol evidence rule.

Assuming the absence of a parol evidence imbroglio, and meeting the issue head on, contract law certainly should not allow a licensor to employ e-disclaimers as part of a strategy to confuse or surprise a consumer. Further, evidence mounts that people do not and will not carefully read their e-standard forms, thereby creating an invitation for licensor opportunism. On the other hand, as a general matter, licensors should be able to rely on the enforcement of their estandard forms, which facilitates commerce and reduces costs for

5 See infra notes 11-15 and accompanying text.

6 ALI PRINCIPLES, supra note $1, \S 1.01$ (i) ("A 'record' is information that is inscribed on a tangible medium or that is stored in an electronic or other medium and is retrievable in perceivable form." (citing UNIF. COMPUTER INFO. TRANSACTIONS ACT (U.C.I.T.A.) § 102(a)(55) (2002) and U.C.C. Revised $\S 1$ $201(b)(31)(2001)))$.

7 ALI PRINCIPLES, supra note 1, $\$ 2.02$, cmt. g ("Many licensors already maintain archival records of website content, including when material was introduced, modified, and removed. Server logs also indicate when and if a web page was modified."). 
licensors and consumers alike. ${ }^{8}$ We therefore should not dispense with the "duty-to-read" principle lightly. ${ }^{9}$ Further, licensors' concern for their reputations should help deter overreaching in an environment in which consumers do not read standard forms but may complain vociferously about the shoddiness of their products and in which they can broadcast their complaints over the Internet to a wide audience. In fact, many, if not most, successful licensors stand behind their products (and produce quality products) to establish good reputations and to increase their bottom lines regardless of their legal liability. Finally, e-disclaimers may be so prevalent that consumers should not be surprised by them even if they purchase products shortly after reading warranties and ignoring the standard form.

In light of the conflicting policies at play, how should contract law address the problem of online warranties and disclaimers? Our view is that contract law's response should depend on whether a reasonable consumer should expect the e-disclaimer to extinguish express warranties. This focus on objective expectations in interpreting contracts, of course, is not novel. We reinforce this approach in the context of e-warranties and disclaimers and construct

${ }^{8}$ Contract law's enforcement of standard forms facilitates commerce in a number of ways:

Standard form exchanges obviously do not constitute the paradigm 'bargain' of classical contract law with the parties on equal footing and each term separately negotiated. Yet standard forms benefit both sellers and consumers. By using the form for each transaction, sellers standardize risks and reduce bargaining costs. Moreover, sellers avoid costly litigation by crafting their form to accommodate various judicial interpretations. Sellers likely pass along some of these savings to consumers in the form of lower prices. Moreover, sellers can best determine the "particular set of terms that "fits" the practical problems and needs that arise ... in carrying out the transactions,' and therefore produce the most efficient allocation of risks for both parties. Consumers also benefit from judicial decisions that weed out offensive clauses. In fact, because of the efficiencies and benefits of standard forms, it is not a reach to predict that the economy would come to a screeching halt without them.

Robert A. Hillman, Rolling Contracts, 71 Fordham L. Rev. 743, 747 (2002) (quoting Todd D. Rakoff, Contracts of Adhesion: An Essay in Reconstruction, 96 HARV. L. REV. 1174, 1230 (1983).

${ }^{9}$ See, e.g., John D. Calamari \& Joseph M. Perillo, ThE LAW OF CONTRACTS § 9-42 (3d ed. 1987) ("[A] party who signs an instrument manifests assent to it and may not later complain that he did not read the instrument or that he did not understand its contents.... The thought is that no one could rely on a signed document if the other party could avoid the transaction by saying that he had not read or did not understand the writing."). 
specific guidelines for assessing expectations. ${ }^{10}$ These guidelines focus on improved disclosure of e-standard forms, but we also discuss problems with the disclosure strategy. We show why disclosure may only be the best of a series of imperfect responses to the problem of e-warranties and disclaimers.

As mentioned, Part I of this paper reports on licensor warranty and disclaimer practices on the Internet. Part II reviews the reasons why consumers generally do not read their standard forms despite the prevalence of disclaimers and other adverse terms. Part III discusses the parol evidence rule's application to the problem. With issues of the admissibility of evidence put to one side, Part IV outlines the factors for determining when contract law should enforce e- express warranties despite the presence of disclaimers.

\section{The DATA}

This section presents our data. At the end of the section, we respond to two possible licensor objections to our conclusion that our data reveal a significant warranty-disclaimer problem.

The source of our data is the Amazon Top one hundred bestselling software titles on November 5, 2007. ${ }^{11}$ As the name implies, Amazon ranks its software by numbers of sales, so our sample consists of software titles likely resident on consumers' computers. Further, because Amazon is an online retailer, consumers who purchase from Amazon likely perform any product research online as well and are therefore more likely to have seen a licensor's online express warranties.

We sought to gather the EULAs for each of the 100 titles. However, thirty-four software licensors did not post their EULAs on their websites. ${ }^{12}$ We removed an additional twelve titles from the remaining sixty-six titles because they were either "upgrade" versions of titles already on our list or their EULAs consisted of a multi-user license. ${ }^{13}$ We then examined the websites and EULAs of the

\footnotetext{
${ }^{10}$ The guidelines are modeled after the ALI PRINCIPLES, supra note 1.

11 Amazon compiles its Top 100 on an hourly basis, so our sample is a snapshot of software titles with some degree of randomness. On November 25, 2007, for example, there were twenty-seven titles that were not on the November 5 list. We did not collect our data on November 5 , but used the date only to compile our list of software titles to investigate.

12 This itself is significant because it shows the lack of visibility of a significant number of EULAs prior to a consumer engaging in a transaction. See infra notes 14, 74-76 and accompanying text.

13 For example, the number-one best "seller" in the Top 100 on November 5 was Apple's Mac OS X Version 10.5 Leopard, while number three was Apple's Mac OS X Version 10.5 Leopard (5-user family pack). The EULA for both programs
} 
remaining fifty-four software titles. ${ }^{14}$ We found that fifteen software licensors produced the fifty-four titles. Because our goal was to examine titles commonly residing on consumers' computers, we were not concerned by the concentration of software licensors in our sample.

We found that fifty-three of the fifty-four EULAs contained disclaimers of express warranties otherwise created on the licensors' websites that may extinguish all or much of the warranty protection. ${ }^{15}$ In addition, fifty-one of the fifty-four titles contain website "terms of use" (as distinguished from a EULA that governs a consumer's purchase) that appear to disclaim website express warranties. ${ }^{16}$

is identical. Similarly, Microsoft Office Professional Upgrade (number 39) has the same EULA as Microsoft Office Professional Full Version (number 30).

14 The EULA in our data for Microsoft Streets and Trips 2008 (number 23) is actually for Microsoft Streets and Trips 2006, and the EULA for Adobe Photoshop Elements 4.0 (Mac) (number 41) is actually for Photoshop Elements 5.0. We kept these two titles in our data, expecting to update these titles when the software developers posted the EULAs on their websites for the actual titles. At the time of this writing, the developers still had not posted the EULAs. We decided not to omit these titles because we believe the EULAs in our data likely represent the EULAs that actually come with the software. In fact, a representative of Microsoft confirmed this for number 23. We note that even well-known and successful software developers apparently fail to post all of the EULAs for their programs and fail to regularly post updated EULAs for new versions of the same software.

${ }^{15}$ Of the fifty-three titles, one Microsoft title (number 19) contains the language "[m]anage your projects ... in one convenient place" that, because of its marginal specificity, is on the borderline between puffing and an express warranty. Another, Nero (number 22), did not disclaim express warranties. We have no reason to believe that the thirty-four titles that hide their EULAs would be less inclined to disclaim their warranties, but even if all thirty-four did not disclaim, at least fifty out of eighty-eight would still have done so.

${ }^{16}$ Some of the "terms of use" are ambiguous as to exactly what is disclaimed. For example, Intuit, the creators of Quicken software set forth the following guarantee on their website:

$100 \%$ Satisfaction Guaranteed. If you're not $100 \%$ satisfied, return Quicken Premier Software 2008 with your dated receipt within 60 days of purchase for a refund of the purchase price (Return shipping and handling charges are not included).

Quicken Premier 2008 Features \& Benefits, http:/quicken.intuit.com/ personal-finance/premier-portfolio-management.jsp (last visited June 16, 2008). However, Intuit's "Terms of Service" "Disclaimer of Warranties" states that

Your use of the Site, including any ... content contained therein, is entirely at your own risk. The service is provided "As Is," and to the maximum extent permitted by applicable law, Intuit . . . disclaim[s] all guarantees and warranties, whether express, implied, or statutory regarding the site and related materials 
However, we believe these latter disclaimers are clearly unenforceable because of the absence of sufficient notice and the lack of acceptance of the terms. ${ }^{17}$ The more difficult question, addressed here, is enforcement of express warranty disclaimers in the EULAs.

We set forth our data consisting of express warranties and EULA disclaimers in Appendix 1. We set forth three examples here that represent the three major categories of express warranty and disclaimer that we found in our data.

The best selling title on November 5, 2007, was Apple Mac OS X Version 10.5 Leopard. Apple states on its website that this software enables the user to "run Windows on your Mac."18 But section 6 of Apple's EULA warrants only that the media that stores the software is free from defects in workmanship and states that the "Limited Warranty set forth herein is the only warranty made to you and is provided in lieu of any other warranties (if any) created by any

including any warranty of fitness for a particular purpose, title, merchantability and non-infringement.

Quicken.com Terms of Service, http:/help.quicken.com/support/ termsofservice/index.shtml (last visited Dec. 12, 2008). The disclaimer governs "use of the Site," and the "service" provided by the site, but the reference to a disclaimer of "content" and "related materials" suggests that the disclaimer covers express warranties on the site.

Similar $100 \%$ satisfaction guarantees are made on the Rosetta Stone website titles, numbers $35,48,66$, and 86 . But these websites' "terms of use" state:

The material on this Website is provided "as is", without any conditions, warranties or other terms of any kind. Accordingly, to the maximum extent permitted by law, Rosetta Stone provides you with this Website on the basis that Rosetta Stone excludes all representations, warranties, conditions and other terms ....

Rosetta Stone: Website Terms and Conditions, $\mathrm{http}: / /$ www.rosettastone.com/global/terms (last visited Dec. 12, 2008).

17 Typically, a consumer can reach the terms of use only if she finds a hyperlink buried at the bottom of a web page somewhere on a licensor's website. This should not constitute sufficient notice. See, e.g., ALI PRINCIPLES, supra note $1, \S$ 2.02 (c)(2) \& cmt. c. Further, courts have found this controversial "browsewrap" presentation unenforceable on offer and acceptance grounds, holding that mere use of the site does not constitute acceptance of the terms of use. See, e.g., Specht v. Netscape Commc'ns Corp., 306 F.3d 17,31-32 (2d Cir. 2002). In addition, as we discuss later, contract law favors express quality assertions over conflicting language that seeks to negate them so even absent notice and formation problems a warranty should trump the terms-of-use disclaimer. See infra notes 67-71 and accompanying text.

18 Apple Mac OS X Leopard, Features, http://www.apple.com/macosx/ features/bootcamp.html (last visited Dec. 12, 2008). 
documentation, packaging or otherwise.," ${ }^{, 19}$ Not to be outdone by this language, section 7 contains an even broader disclaimer:

Except for the limited warranty on media set forth above ... the Apple Software and Any services performed or provided by the Apple Software ("Services") are provided "As Is", with all faults and without warranty of any kind, and Apple and Apple's Licensors ... hereby disclaim all warranties and conditions with respect to the Apple Software and any services, either express, implied or statutory ... ${ }^{20}$

The effect of the language of both sections, of course, is that a consumer expecting to "run Windows on [her] Mac" may be sorely disappointed to learn that Apple does not have to stand by its assertion that the software will work. Although the EULAs in our sample varied in form and language, we can fairly place eighteen of the fifty-three EULAs within this first category. ${ }^{21}$

A second representative example, is the "Limited Warranty" in Microsoft Office Home and Student 2007 EULA (number two on the list of the Top 100), which states that "the software will perform substantially as described in the Microsoft materials that you receive in or with the software." 22 The disclaimer in the Limited Warranty then states that "Microsoft gives no other express warranties, guarantees or conditions. ${ }^{, 23}$ Therefore the express promise made on Microsoft's website that the software supports Portable Document

19 Mac OS X (Leopard) Software License, http://images.apple.com/legal/sla/ docs/macosx 105.pdf (last visited Nov. 24, 2008).

${ }^{20} \mathrm{Id}$.

${ }^{21}$ The eighteen titles are $1,5,8,9,11,12,33,34,36,44,61,63,67,73,75,79,84$, 93. To complete the picture of this category, the Intuit titles (numbers 5, 11, 33, $34,44,63,73,75$, and 93) contain "satisfaction" guarantees in their EULAs, authorizing for a limited time a return of the software for a refund, notwithstanding the EULAs' disclaimers of express warranties. Although these guarantees offer some protection, consumers may still be enticed to enter a transaction because of express warranties, but fail to take advantage of the guarantee because of the guarantee's limited time and other requirements. Further, a consumer cannot seek consequential damages for breach of the express warranties or otherwise enforce them under the satisfaction clause.

22 Retail Software License Terms for Microsoft Office Home and Student 2007, Limited Warranty, $\& \mathrm{~A}$, http://download.microsoft.com/documents/ useterms/Office\%20Home\%20and\%20Student_2007_English_bc25f42d-51 f94e57-8a41-846bca63054a.pdf (last visited June 16, 2008).

${ }^{23} I d . \S \mathrm{G}$. 
Format (PDF) would not be covered by their limited warranty unless Microsoft repeats this promise in the materials a consumer receives "in or with the software." 24 In other words, by virtue of the disclaimer, Microsoft's website itself is incapable of providing any express warranties to the end user. Twenty-one EULAs belong in this category. ${ }^{25}$

A third set of disclaimers seem ambiguous on whether they disclaim express warranties made on the website, but courts likely would find that they do so. For example, Microsoft states on its website that Windows XP Professional with Service Pack 2 (number 32) allows users to access their work computer from their home computer. Further, the website claims that "when you connect to your computer at work, Remote Desktop automatically locks that computer so no one else can access your applications and files while you are gone." 26 Nevertheless, section 18 of the EULA disclaims any express warranties that are not in the limited warranty of section 17 , which provides that the software will perform "substantially in accordance with accompanying materials."27 But the EULA nowhere defines "accompanying materials" and section 18 states that "advertising, documentation, packaging, or other communications"

24 For a discussion of the materials that accompany the software, see infra notes 29-31 and accompanying text.

${ }^{25}$ Titles 2, 13, 15, 23, 24, 30, 31, 35, 47, 48, 50, 56, 57, 64, 66, 81, 83, 86, 89, 97, 99 belong in this category. Although disclaiming express warranties, titles 13, 24 , and 99 also allow a return of the software for a limited time for "defects" in material or workmanship.

${ }^{26}$ Windows XP Professional Overview: Access Files and Applications Remotely, http:/www.microsoft.com/windowsxp/evaluation/features/remoteaccess.mspx (last visited June 16, 2008).

27 Section 18's disclaimer provides:

The Limited Warranty that appears [in section 17] is the only express warranty made to you and is provided in lieu of any other express warranties or similar obligations (if any) created by any advertising, documentation, packaging, or other communications. Except for the Limited Warranty and to the maximum extent permitted by applicable law, Microsoft and its suppliers provide the software and support services (if any) AS IS AND WITH ALL FAULTS, and hereby disclaim all other warranties and conditions, whether express, implied or statutory . ...

Microsoft Windows XP Professional: End-User License Agreement, $\S 18$, http://download.microsoft.com/documents/useterms/Windows\%20XP\%20SP2 Pr ofessional_English_29e61d64-43e3-4ca3-b201-fe0c62507034.pdf (last visited Nov. 24, 2008). 
do not create express warranties, ${ }^{28}$ leaving as a mystery whether "accompanying materials" includes website promises and representations. Nevertheless, Microsoft's "terms of use" of its website disclaims any express warranties created by the website, suggesting that Microsoft did not intend "accompanying materials" to include website materials. ${ }^{29}$ Microsoft's set of disclaimers means that website promises and representations likely are not legally enforceable. Fourteen EULAs contain this kind of ambiguity. ${ }^{30}$

A licensor may argue that disclaimers of website promises are irrelevant if the licensor makes the same promise in the "materials in or with the software." For example, suppose Microsoft repeats its PDF representation somewhere in their "materials." However, our data suggests that consumers cannot rely on a licensor's "materials" repeating website promises and representations and that the potential for overreaching by licensors is strong. First, the data shows that licensors go to great lengths to disclaim promises made on their websites. It is hard to explain why they would do so if their "materials" contain the same promises and, in fact, our further investigation of these materials, although limited to those available, revealed that some do not. ${ }^{31}$ Further, some "materials" contain

${ }^{28} \mathrm{Id}$.

29 Microsoft - Information on Terms of Use, http://www.microsoft.com/info/cpyright.mspx (last visited Nov. 24, 2008).

30 Titles $4,6,19,21,32,38,40,41,52,53,55,58,62,70$ belong in this third category.

31 We sought to track down whether licensors that provided that their software would perform "substantially in accordance with accompanying materials or documentation" repeated their website express promises and representations in their "accompanying materials". However, many of these "materials" were unavailable without a purchase. From those that were available, a small sample yielded mixed results. Four user guides (numbers 6, 50, 53 and 57) were lengthy and thorough, explicitly repeating the representations captured in our appendix (and probably most if not all of what is on the licensor's website); however, two of these user guides from Adobe (numbers 6 and 53) contained the following disclaimer:

The content of this guide is furnished for informational use only, is subject to change without notice, and should not be construed as a commitment by Adobe Systems Incorporated. Adobe Systems Incorporated assumes no responsibility or liability for any errors or inaccuracies that may appear in the informational content contained in this guide.

Adobe Photoshop Elements 6 User Guide, at ii (2007), http://help.adobe.com/en_US/PhotoshopElements/6.0/pselements_6_help.pdf; Adobe Acrobat $8.0^{\circ}$ Professional User Guide, at ii (2007), http:/help.adobe.com/en_US/Acrobat/8.0/Professional/help.pdf. 
disclaimers of their own or narrow the promises and representations made on the website. ${ }^{32}$ Second, Microsoft and others promise only that the software will perform "substantially" as promised in the "materials," itself potentially a significant reduction in quality protection. Third, there appears to be little incentive for licensors to repeat promises and representations after a purchase regarding the software's capabilities. We should also point out that our data reveals the warranty/disclaimer approaches of very successful software licensors. Apparently Apple's current strategy of disclaiming virtually all warranties is not negatively influencing sales. It is likely that less successful licensors and fly-by-night operations, focusing on the bottom line and wary of the costs of warranty services, already follow or will follow Apple's lead. ${ }^{33}$

A licensor may also claim that it stands behind its product no matter what a disclaimer says, so that the problem we address is

Adobe Acrobat 8.0 Standard (number 38) contains the same disclaimer in its user guide. Adobe Acrobat 8.0 Standard User Guide, at ii (2007), http://help.adobe.com/en_US/Acrobat/8.0/Standard/help.pdf. Further, the representations on their website appear broader than in the user guide. The representation on the website provides: "Save Adobe PDF files as Microsoft Word documents, retaining the layout, fonts, formatting, and tables, to facilitate reuse of content." Adobe Acrobat 8 Standard, http://www.adobe.com/products/acrobatpro/acrobatstd.html (last visited Mar. 31, 2008). However, the instruction in the user guide contains the following:

If you don't have the original file from which a PDF was created, you can save the PDF as a Word document that you can then edit in Word.... Note: When you save a PDF to Word format, the resulting file isn't equivalent to a file created in Word; some coding information may be lost.

Adobe Acrobat 8.0 Standard User Guide, supra, at 131. See also id. at 136.

The universal user guide furnished by Rosetta Stone for the four titles on our list (numbers 35, 48,66, and 86) do not repeat their website representations captured in our appendix. However, even if the representations were included in the guide, the following disclaimer is set forth on page ii of the user guide:

All information in this document is subject to change without notice. This document is provided for informational purposes only and Rosetta Stone Ltd. makes no guarantees, representations or warranties, either express or implied, about the information contained within the document or about the document itself.

Rosetta Stone User's Guide, at ii (2007), http:/www.rosettastone.com/us_assets/ documentation/RSV3_UG_CD_English_(US).pdf.

32 See supra note 31.

33 Additionally, start-up software licensors are most likely to transfer problematic software and therefore be more interested in disclaiming warranties. 
irrelevant. We believe otherwise. First, as already noted, we present information about successful licensors and surmise that plenty of less successful licensors will not stand behind their products (even if they say they will). Second, sellers have invoked their disclaimers against warranties in hosts of cases in the paper world, suggesting that elicensors will act no differently. ${ }^{34}$ Third, the argument that licensors will "do the right thing" proves too much. If accepted, the argument means that we do not need contract law at all. Let's just trust in the good faith of all businesses. Finally, perhaps most important and as the discussion in the next Part reveals, conditions in the online environment for overreaching may be too inviting for licensors uniformly to stand behind their warranties.

\section{The e-STANDARd Form Environment}

In this section, we describe the e-standard form environment. We observe that consumers do not read e-standard forms and that this creates the opportunity for licensor opportunism. We argue that contract law should therefore intercede.

Professors Hillman and Rachlinski have compared the paper and online environments of standard-form contracting. They identified certain factors in the online world that should promote reading of e-standard forms by consumers:

Several factors suggest that consumers can defend themselves against undesirable terms more easily in the electronic environment. E-consumers can shop in the privacy of their own homes, where they can make careful decisions with fewer time constraints. They can leave their computers and return before completing their transactions, giving them time to think and investigate further. Also, at present, econsumers tend to be better educated and wealthier than paper-world consumers, suggesting that they can better fend for themselves in the marketplace.

The Internet has also taken comparison shopping to a level that is unimaginable in the real world. The ease with which consumers can compare business

\footnotetext{
${ }^{34}$ See, e.g., Inter-Mark USA, Inc. v. Intuit, 2008 U.S. Dist. LEXIS 18834 (Feb. 27, 2008 N.D. Cal.) (dismissing a claim for breach of implied warranty of merchantability because of the software's disclaimer of warranties); Jordan v. Doonan Truck \& Equip., 552 P.2d 881 (Kan. 1976) (holding that evidence of an oral express warranty that a truck would run for three to four months without any work was inadmissible because the disclaimer of warranties was the final expression of the parties' agreement).
} 
practices, including the content of standard forms, suggests that consumers do not need judicial intervention to protect themselves from business abuse. $^{35}$

Notwithstanding these advantages, some aspects of e-contracting raise concerns about the quality of assent to e-standard forms. Hillman and Rachlinski described these factors as either rational, cognitive, or social in nature, all leading to the conclusion that econsumers are not likely to read terms. In another paper, Hillman summarized how these factors operate to discourage reading:

The rational factors overlap explanations from the paper world about why people do not read their forms, such as the impenetrability of most boilerplate, the ability of e-businesses to present the forms in a manner that deters reading, consumers' lack of bargaining power (indeed the lack of anyone with whom to bargain), the lack of diversity of terms within an industry, and the knowledge that boilerplate generally allocates the risks of remote contingencies. In short, an e-reader may weigh the costs and benefits of reading and not reading and rationally find a net benefit in not reading.

Cognitive factors for failing to read are irrational, but prominent, both in the paper and electronic worlds. They include consumers' propensity to underestimate the likelihood of adverse events and their tendency to rely on intuition and hunches instead of processing all of the information.

At first blush, social factors that affect how consumers treat standard forms would seem to be very different and favorable to e-consumers reading more [mainly because of the absence of a live agent applying pressure on the consumer to sign precipitously]. . .

Despite th[is] potential advantage[ $]$ for consumers ... the likelihood is that e-consumers [will] not assign the same significance to a mouse click as a signature on a paper form. ... [E]-consumers are conditioned to

${ }^{35}$ Hillman \& Rachlinski, supra note 3, at 478. 
expect speed and instant gratification when using their computers, including when they engage in Internet contracting. Put differently, consumers may be overeager, even "click-happy" and may therefore fail to research their e-standard contracts. ${ }^{36}$

In light of these factors, Hillman and Rachlinski predicted that consumers would resemble their counterparts in the paper world who fail in large part to read or comprehend their standard forms. To test these assumptions, Hillman administered a survey to his first-year class of ninety-two contracts students. The results and explanations are reported elsewhere. ${ }^{37}$ Suffice it to say here that, for the most part, the survey results support the assumption that consumers generally do not read their e-standard forms. ${ }^{38}$

Assuming we cannot expect consumers to read e-standard forms what, if anything, should contract law do about the problem? As noted in the introduction, a basic and deeply embedded rule of contract law is that people should be bound to terms when they have an opportunity to read their contracts and signify their acceptance. ${ }^{39}$ And for good reason. Licensors have better information about their products and the various problems that can arise than lawmakers who would have to substitute their judgments for those of the licensors. Nor is the use of standard forms necessarily disadvantageous to consumers. Analysts frequently point out that the use of standard forms reduces costs for licensors, which they can pass on to consumers. $^{40}$ Finally, even in competitive markets disclaimers are sufficiently common that consumers arguably should expect them

${ }^{36}$ Robert A. Hillman, Online Consumer Standard Form Contracting Practices: A Survey and Discussion of Legal Implications, in CONSUMER PROTECTION IN THE AGE OF THE "INFORMATION ECONOMY" 285 (2006) [hereinafter Hillman, Survey].

37 Id. at $286-94$.

38 Id. The survey found that few respondents read their e-standard forms beyond price and description of the goods or services "as a general matter." Further, beyond price and description, a large minority of respondents do not read their forms at all. However, more than a third of the respondents read their forms when the value of the contract is high and more than a third read when the licensor is unknown. Further, a small cadre of respondents read particular terms beyond price and description, primarily warranties and product information warnings. $I d$.

The survey also illustrates that impatience accounts most often for the failure of respondents to read their forms. Not surprisingly, therefore, the survey also reveals that respondents rarely shop for advantageous terms, despite their greater availability on the Internet. $I d$.

39 See supra note 9 , reciting the duty-to-read rule.

40 See supra note 8 and accompanying text. 
whether or not they read their standard forms. ${ }^{41}$

On the other hand, there are good reasons not to be complacent about enforcing e-standard forms, including express warranty disclaimers. The conditions for licensor opportunism are too great to adopt a "hands off" policy on the grounds of freedom of contract and the duty to read. First, our data shows that licensors are not reticent to make rather bold claims about their products on their websites only to reverse position on their standard forms. ${ }^{42}$ These

${ }^{41}$ For a recent judicial defense of form contracts, see IFC Credit Corp. v. United Bus. \& Indus. Credit Union, 512 F.3d 989, $992-93$ (7th Cir. 2008) (Easterbrook, C.J.):

Ever since Carnival Cruise Lines, Inc. v. Shute, 499 U.S. 585 , 111 S.Ct. 1522, 113 L.Ed.2d 622 (1991), enforced a forumselection clause printed in tiny type on the back of a cruise-ship ticket, it has been hard to find decisions holding terms invalid on the ground that something is wrong with non-negotiable terms in form contracts.... As long as the market is competitive, sellers must adopt terms that buyers find acceptable; onerous terms just lead to lower prices. ... If buyers prefer juries, then an agreement waiving a jury comes with a lower price to compensate buyers for the loss - though if bench trials reduce the cost of litigation, then sellers may be better off even at the lower price, for they may save more in legal expenses than they forego in receipts from customers.

There is no difference in principle between the content of a seller's form contract and the content of that seller's products. The judiciary does not monitor the content of the products, demanding that a telecom switch provide 50 circuits even though the seller promised (and delivered) 40 circuits. It does not matter that the seller's offer was non-negotiable (if, say, it offered 40circuit boxes and 100-circuit boxes, but nothing in between); just so with procedural clauses, such as jury waivers. As long as the price is negotiable and the customer may shop elsewhere, consumer protection comes from competition rather than judicial intervention. Making the institution of contract unreliable by trying to adjust matters ex post in favor of the weaker party will just make weaker parties worse off in the long run.

For recent defenses of boilerplate in the law reviews, see, for example, Lucian A. Bebchuk \& Richard Posner, One-Sided Contracts in Competitive Consumer Markets, 104 MiCH. L. REV. 827 (2006); and Jason S. Johnston, The Return of Bargain: An Economic Theory of How Standard-Form Contracts Enable Cooperative Negotiation Between Businesses and Consumers, 104 MiCH. L. REV. 857 (2006).

${ }^{42}$ See supra notes 15-30 and accompanying text; see also Appendix 1. For another example, Intuit's Quicken 2008 software (number 75) states that "Quicken can now import your transaction data directly from PayPal." Quicken Deluxe ${ }^{\circledR}$ Software: What's New in 2008, http://quicken.intuit.com/personalfinance/deluxe-money-management.jsp (last visited June 16, 2008). The EULA "disclaim[s] all guarantees and warranties, whether express, implied, or statutory, regarding the software. . .." Quicken 2008 End User License Agreement, 
circumstances are likely to mislead consumers, regardless of whether they read their e-standard forms, especially if the claims are sufficiently clear and distinct to constitute express warranties and the consumer reads the promises and representations shortly before committing to a purchase. Even consumers who have become inured to everyday puffing and boasting in general advertising about products likely rely more heavily on licensor promises and representations when they appear on websites only a few clicks away from a purchase.

Second, the collection of "dangerous terms" already appearing on various "watchdog" websites provides evidence that licensors are not beyond taking advantage of the conditions of e-commerce. ${ }^{43}$ Common suspect terms in the software arena, for example, include those that authorize licensors to add spyware to a consumer's computer, that provide for unilateral modification of terms by the licensor without notice or an opportunity to contest the changes, that extend the duration of a contract automatically, and that authorize the licensor to cancel a contract without notice. ${ }^{44}$ Our data suggests that we can add deceptive e-warranty disclaimers to this list.

Third, contract law should help create the appearance of fairness in e-contracting in order to encourage consumers to engage in the process. Relatedly, as a matter of fairness and ethics, licensors should keep their promises. There is little reason why the law should adopt a lesser standard in the e-context than morality would dictate. For example, there is little danger that holding licensors to their express warranties will flood courts with litigation or disrupt the operation of otherwise clear and distinct rules. As we have already mentioned, most licensors already stand behind their products regardless of the legal rules that apply.

Some analysts argue that in competitive markets only a small number of readers may deter licensor opportunism. ${ }^{45}$ Licensors want to establish good reputations to ensure a market share and a few readers and watchdog groups that already exist in abundance on the

http:/help.quicken.com/support/eula/cula_qw2008/(last visited Nov. 24, 2008). The EULA does include a "satisfaction guaranteed" term, but see supra note 21.

${ }^{43}$ See ALI PRINCIPLES, supra note 1, at 155 n.23. See also Larry Magid, It Pays to Read License Agreements, http://www.pcpitstop.com/spycheck/eula.asp (last visited Dec. 12, 2008); Annalee Newitz, Dangerous Terms, A User's Guide to EULAs, Electronic Frontier Foundation, http://www.eff.org/wp/dangerous-termsusers-guide-eulas (last visited Dec. 12,2008). But see Ronald J. Mann \& Travis Siebeneicher, Just One Click: The Reality of Internet Retail Contracting, 108 COLUM. L. REV. 984 (2008).

${ }^{44}$ See ALI PRINCIPLES, supra note $1, \S 1.11 \mathrm{cmt}$. c.

45 See Alan Schwartz \& Louis L. Wilde, Imperfect Information in Markets for Contract Terms: The Examples of Warranties and Security Interests, 69 VA. L. REV. 1387, 1409 (1983). 
Internet can easily spread the word electronically if a licensor writes unfair terms. ${ }^{46}$

This line of argument, often addressed in the literature, is problematic because the number of readers may be too small to impact a licensor's reputation and watchdog groups, at least so far, have only been marginally effective. ${ }^{47}$ Further, licensors in competitive industries can employ new e-technologies to segregate readers and offer them more advantageous terms. "Careful segregation of consumers on the basis of their willingness to read and shop for terms would ensure that the small number of careful consumers would not discipline businesses concerning terms they offer to the rest of the consumers and would allow businesses to take advantage of the latter." 48 In addition, licensors can experiment and determine the types of presentation of terms that best discourage reading. ${ }^{49}$ Nowhere may be more important to intercede than in the context of disclaimers of express warranties that not only induce consumers to enter transactions but that also create fundamental quality expectations. ${ }^{50}$

Parts I and II demonstrate that licensors make express warranties on their websites, that consumers generally do not read the e-disclaimers in their EULAs, that this creates the incentive for opportunism, and that evidence of overreaching already exists. The next two Parts of this paper consider how contract law should treat eexpress warranty disclaimers in light of these realities. First, in Part III, we look at the parol evidence rule and then, in Part IV, we turn to the issue on the merits.

\section{The Parol Evidence Rule in the Electronic Age}

Our data supports the view that licensors make specific and verifiable representations and promises on their websites that constitute express warranties under current law. ${ }^{51}$ Thus, our starting

46 See Hillman \& Rachlinski, supra note 3, at 469-70 \& n.222; Avery Katz, Standard Form Contracts, in 3 NEW PALGRAVE DiCTIONARY OF ECONOMICS AND THE LAW 505 (Peter Newman ed., 1998) ("If reputational concerns lead drafters of forms to moderate their opportunism, regulation may be largely unnecessary.").

47 See, e.g., Hillman \& Rachlinski, supra note 3, at 443; ALI PRINCIPLES, supra note $1, \S 2.02 \mathrm{cmt}$. h.

${ }^{48}$ Hillman \& Rachlinski, supra note 3 , at 472

49 Id. at 481-82; Hillman, Survey, supra note 36, at 290-92.

50 Express warranties "must be objective in nature, i.e., verifiable or capable of being proven true or false." Boud v. SDNCO, Inc., 54 P.3d 1131, 1135 (Utah 2002). See supra notes 16-26 and accompanying text.

51 See infra, Appendix. 
point is that a licensor's representation or promise constitutes a "basis of the bargain" if a court applies UCC section 2-313, or that a reasonable consumer could rely on the statement if a court applies section 3.02 of the ALI Principles. ${ }^{52}$ Under this set of assumptions, the threshold question is whether the parol evidence rule bars evidence of the express warranty if the e-standard form disclaims such warranties and includes a "full integration" clause.

The parol evidence rule bars evidence of prior or contemporaneous representations and promises that contradict an unambiguous record that the parties intended to be complete. ${ }^{53}$ Suppose, for example, a consumer alleges that a software licensor represented on its website that its software "is compatible with the Ultrix operating system," when it is not. ${ }^{54}$ The e-standard form disclaims all express and implied warranties and includes a full integration clause. The parol evidence rule, at least in its traditional form in the paper world, bars the admissibility of the express warranty because it is inconsistent with the standard form.

Courts and writers have spilled plenty of ink advocating the abolishment of the parol evidence rule for reasons not unlike the problem presented here, namely that the rule, designed to deter fraud, tends to encourage it by allowing contracting parties to shield themselves from their actual promises and representations. In fact, because the parol evidence rule aids and abets such conduct, courts often find exceptions to, or manipulate, the rule if they believe that the evidence offered is true. Among a host of exceptions and manipulations, three are pertinent here: courts admit extrinsic evidence (1) if the parties did not intend the record to be complete on the issue at hand; (2) if the evidence would reveal fraud or another invalidating cause; or (3) if the evidence consists of a course of performance, course of dealing, or usage of trade. ${ }^{55}$

52 The ALI sought to promulgate the Principles of the Law of Software Contracts to govern software transactions directly. See ALI PRINCIPLES, supra note 1, at 2223. The UCC's "basis of the bargain" test for determining the existence of an express warranty has caused confusion over precisely what the test means. Id. $\S$ 3.02 , cmt. b. The ALI Principles have therefore adopted a new test based on whether a copyholder could reasonably rely on the words or conduct, a test based on the UCC commentary explaining the meaning of "basis of the bargain." Id.

${ }^{53}$ See, e.g., id. $\S 3.08$.

54 See id. $\$ 3.02$, illus. 1.

${ }^{55}$ See, e.g., Eskimo Pie Corp. v. Whitelawn Dairies, Inc., 284 F. Supp. 987, 991 (S.D.N.Y. 1968) (course of performance, usage of trade, course of dealing); Mitchill v. Lath, 160 N.E. 646, 647 (N.Y. 1928) ("[A]n inspection of the written contract, read in the light of surrounding circumstances, must not indicate that the writing appears to contain the engagements of the parties, and to define the object and measure the extent of such engagement.") (internal quotations omitted); Johnson Bldg. Co. v. River Bluff Dev. Co., 374 N.W.2d 187, 193 (Minn. App. 1985) ("The parol evidence rule is inapplicable to exclude evidence of fraudulent 
Some courts determine whether a record is complete based on its plain meaning, including the meaning of any integration clause. ${ }^{56}$ However, many courts, following Corbin and Llewellyn, admit all relevant evidence preliminarily to determine whether the parties intended the record to be complete before applying the parol evidence rule, sometimes even if the record contains a full integration clause. ${ }^{57}$ Needless to say, credible evidence of representations and promises that are inconsistent with a record usually means that the parties did not intend to integrate their agreement completely, at least if they are in good faith. If a licensor says its software is compatible with Ultrix, a transferee can justifiably assert that the record is not complete on the compatibility issue notwithstanding an e-disclaimer and integration clause. A court sympathetic with this argument can entertain the evidence preliminarily, conclude that the record is incomplete, and admit the evidence for purposes of determining the parties' substantive rights. In truth, however, in most cases neither the licensor nor consumer probably thought about the completeness of the e-standard form, nor has either party read it. The situation is not unlike the merchant-to-merchant battle-of-the-forms fiasco, in which the UCC and courts have wisely turned their focus away from the text of the forms. ${ }^{58}$

Despite the parol evidence rule, many courts also admit evidence of fraudulent misrepresentation, duress, mistake, or the like on the theory that such evidence establishes the unenforceability of an agreement (including any warranty disclaimer). If a licensor warrants that its software is compatible with Ultrix when it knows that it is not

oral representations by one party which induce another to enter into a written contract.").

Determining what constitutes "the record" that the parties intend to be complete constitutes a fourth potential exception. If the fully-integrated record includes promises and representations made on the website, then there is no parol evidence issue, only one of interpretation of the conflicting terms.

${ }^{56}$ Harrison v. Fred S. James, P.A., Inc., 558 F.Supp. 438, 442 (E.D.Pa 1983).

57 See, e.g., Rumsfeld v. Freedom NY, 329 F.3d 1320, 1328-29 (Fed. Cir. 2003) ("Like 'most courts' we elect to follow the 'traditional rule' ... namely that an integration clause 'conclusively establishes that the integration is total unless (a) the document is obviously incomplete or (b) the merger clause was included as a result of fraud or mistake or any other reason to set aside the contract." (quoting Calamari \& Perillo, supra note 9, § 3.4(c)); Johnson Bldg. Co., 374 N.W.2d at 193 ("The fact that the purchase agreement contained a 'full integration' clause does not alter our conclusion that the trial court properly admitted parol evidence. A 'full integration' clause does not prevent proof of fraudulent representations by a party to the contract.").

58 See U.C.C. § 2-207; Douglas G. Baird \& Robert Weisberg, Rules, Standards, and the Battle of the Forms: A Reassessment of $\$ 2-207,68$ VA. L. REV. 1217 (1982). 
and this information is not readily available to the transferee, the evidence of this misrepresentation should be admissible. ${ }^{59}$ Further, evidence that the licensor presented the e-disclaimer in a manner meant to discourage the consumer from reading the e-disclaimer would substantiate the misrepresentation or by itself may constitute actionable concealment. ${ }^{60}$

Courts also admit evidence of course of performance, course of dealing, or usage of trade because they are reliable indicators of the meaning of contract language. ${ }^{61}$ For example, a court may admit evidence that a licensor repeatedly replaced a consumer's software that is incompatible with Ultrix, which course of dealing may establish such a duty notwithstanding an e-disclaimer of express warranties and an integration clause. ${ }^{62}$ In addition, a court may admit evidence of a trade custom that software licensors in a particular "place, vocation, or trade" consistently stand behind their e-express warranties, notwithstanding disclaimers. ${ }^{63}$

Although these and other exceptions show that the parol evidence rule is porous and confusing, the ALI Principles seek to clarify the rule by codifying the results suggested in the Ultrix example above. The ALI Principles direct courts to admit extrinsic evidence to determine whether the parties intended a full or partial integration prior to application of the parol evidence rule. The Principles also provide for the admissibility of evidence of misrepresentation, "course of performance, course of dealing, or usage of trade." ${ }^{64}$ Finally, the Principles hold in the consumer

${ }^{59} \mathrm{~A}$ fraudulent misrepresentation occurs if a party knows that the representation is false or the party makes the representation recklessly, with the intention of inducing the other party to rely, which the other party does. Gibb v. Citicorp Mortgage, Inc., 518 N.W.2d 910, 916 (Neb. 1994).

${ }^{60} \mathrm{~A}$ fraudulent concealment occurs if a party conceals a material fact that is not within the reasonable observation of the other party in order to mislead that party. Gibb, 518 N.W.2d at 916.

${ }^{61}$ See, e.g., Eskimo Pie Corp. v. Whitelawn Dairies, Inc., 284 F. Supp. 987, 991 (S.D.N.Y. 1968).

62 The UCC proclaims that express terms trump course of dealing, but directs courts to construe them consistently if possible. See U.C.C. § 1-303(e)(1) (2001).

${ }^{63} \mathrm{Id}$.

${ }^{64}$ ALI PRINCIPLES, supra note $1, \S 3.08$ provides:

Integration and Parol Evidence

(a) A full integration constitutes a record or records intended by the parties as a complete and exclusive statement of the terms of an agreement. A partial integration constitutes a record or records intended by the parties as the complete and exclusive statement of one or more terms of an agreement.

(b) The court should determine whether a record is fully 
context that an integration clause is "probative but not conclusive" evidence on integration. ${ }^{65}$

An alternative approach would be to abandon the parol evidence rule in its entirety, at least in the case of consumer e-express warranties and disclaimers, on the theory that the cost of administering the rule outweighs its usefulness. After all, the problem is not with proof of the existence of a warranty-records and logs of a website make this incontestable. ${ }^{66}$ The issue is whether the edisclaimer extinguishes what would otherwise be the licensor's legal duty to stand behind its quality claims. Instead of complicating the issue by entertaining claims of inadmissibility of evidence, courts should receive all pertinent evidence, not as a preliminary step with the evidence out of the reach of the trier of fact, but as probative

integrated, partially integrated, or not integrated prior to applying subsections (e) and (f). In making this determination, the court should consider all credible and relevant extrinsic evidence, including evidence of agreements and negotiations prior to or contemporaneous with the adoption of the record.

(c) If the transfer is a standard-form transfer of generallyavailable software, a term in a record indicating that the record is fully integrated or partially integrated should be probative but not conclusive on the issue.

(d) The court should determine whether a term in a record is ambiguous prior to applying subsections (e) and (f). In making this determination, the court should consider all credible and relevant extrinsic evidence, including agreements and negotiations prior to or contemporaneous with the adoption of the record. If a term or terms is ambiguous, extrinsic evidence is admissible to prove the meaning of the term or terms.

(e) Unambiguous terms set forth in a fully integrated record may not be contradicted by evidence of any prior agreement or of a contemporaneous oral agreement, but may be explained by course of performance, course of dealing, or usage of trade.

(f) Unambiguous terms set forth in a partially integrated record may not be contradicted by evidence of conflicting terms, but may be explained by evidence of course of performance, course of dealing, usage of trade, or consistent additional terms.

(g) Notwithstanding subsections (e) and (f),

(1) evidence is admissible to prove

(A) illegality, fraud, duress, mistake, or other invalidating causes; and

(B) independent agreements; and

(2) evidence of course of performance, course of dealing, and usage of trade is admissible to supplement a record.

${ }^{65} I d . \S 3.08(\mathrm{c})$.

66 See supra note 6 and accompanying text. 
evidence on the merits. We turn to these merits in the following section.

\section{ENFORCEMENT OF E-DISCLAIMERS}

In this section, we assume the absence of a parol evidence bar, so we are left with the question of whether, as a substantive matter, contract law should enforce e-disclaimers if the licensor has made express warranties on its website. The UCC and the ALI Principles recognize the potential incompatibility of express warranties and disclaimers. ${ }^{67}$ UCC $\S 2-316(1)$ directs courts to strike disclaimers that are "inconsistent" with an express warranty, but the section exhorts courts to try to find consistency and implies that such an interpretation can be found ${ }^{68}$ One can argue that the UCC is asking courts to do the impossible: How can a court find a consistent interpretation of contradictory language? Unsurprisingly, judicial application of $\S 2-316(1)$ has been inconsistent and incoherent. ${ }^{69}$ The ALI Principles, on the other hand, direct courts to strike "unexpected" e-disclaimers. ${ }^{70}$ Arguably this approach is clearer and is consistent with what the UCC drafters were trying to achieve: Comment 1 to $\S$ 2-316 states that subsection (1) is meant to "protect a buyer from unexpected . . language of disclaimer . ...,"71

The issue thus boils down to an analysis of what conditions must exist for a court to find that an e-disclaimer is unexpected. The legal framework already exists for such an analysis. Although the approach has many labels, including "reasonable expectations" and "unconscionability," contract law largely follows Karl Llewellyn's admonition to presume "blanket" assent to conscionable boilerplate, but only if a party had reasonable notice of and opportunity to read the standard form. ${ }^{72}$ This strategy's emphasis on consumer

${ }^{67}$ See supra notes 16-26 and accompanying text.

${ }^{68}$ Section 2-316 directs courts to interpret language or conduct creating warranties and language or conduct negating them as "consistent" unless unreasonable: "Words or conduct relevant to the creation of an express warranty and words or conduct tending to negate or limit warranty shall be construed wherever reasonable as consistent with each other ... negation or limitation is inoperative to the extent that such construction is unreasonable." See Ajay Ayyappan, UCITA: Uniformity at the Price of Fairness?, 69 FORDHAM L. REV. 2471, 247885 (2001).

69 See ALI PRINCIPLES, supra note $1, \S 3.06, \mathrm{~cm}$. a, and cases cited therein.

${ }^{70}$ See ALI PRINCIPLES, supra note 1, § 3.06(a).

${ }^{71}$ Emphasis added. The ALI Principles follow this comment in $\S 3.06$, but omit the superfluous "unbargained" language.

${ }^{72}$ Hillman, supra note 8, at 755. This relied on Karl Llewellyn, The Common Law Tradition: Deciding Appeals 370 (1960). See also K. N. Llewellyn, Book Review, 52 HaRV. L. REV. 700, 704 (1939) (reviewing O. PRAUSNITZ, THE 
delegation to licensors of the drafting of boilerplate preserves the semblance of autonomous choice in the context of standard forms and should remain attractive in the electronic era. ${ }^{73}$ What factors should courts therefore focus on in determining the adequacy of notice and the opportunity to read the e-disclaimer? And how should courts determine if a disclaimer is "conscionable"?

The ALI Principles furnish some guidance. They call for software licensors to make terms, including disclaimers, easily accessible on their websites prior to a transaction and to give reasonable notice of and access to the terms if a licensee initiates a transaction. $^{74}$

Initiation of a transaction occurs only when the consumer intends to contract and has begun that process, such as by clicking on a "purchase" or "I agree" icon before the consumer gives payment information. Accessibility of terms on a website prior to initiation enables prospective customers to read and compare terms without making a commitment. In fact, it is just such accessibility, albeit with some searching, that enabled us to peruse the standard forms discussed in Part I of this paper (and should make enforcement of those disclaimers more likely). A reasonably clear notice of the availability of terms on the licensor's homepage should suffice. Further, the notice should be conspicuous based on placement and size (bold print or a large font should do) and should constitute a hyperlink that leads directly to the standard form. ${ }^{75}$ The standard form itself should also be conspicuous on the computer screen.

Once a transferee initiates a transaction, licensors should require a "clickwrap" acceptance of the e-standard form. Clickwrap most closely resembles the signing of a paper standard form because clickwrap requires the consumer to consent to presented terms by clicking "I agree" (or the like) before completing the transaction.

STANDARDIZATION OF COMMERCIAL CONTRACTS IN ENGLISH AND CONTINENTAL LAW (1937)) (asserting that the presumption of assent does not apply to "utterly unreasonable clauses").

73 "[D]ifficulties arise in determining when a contracting party has sufficient information about the contract subject matter or future course of events affecting the value of the contract subject matter for a conclusion to be sustained that the choices in question were autonomous. Although contracting choices made with false information or in the absence of highly material information may, at one level, be regarded as non-autonomous, at another level the decision to forgo opportunities to acquire further information may itself be an autonomous choice." Michael Trebilcock, THE Limits OF FreEdOM OF CONTRACT 242 (1993).

74 ALI PRINCIPLES, supra note $1, \S 2.02$. Our data reveals that $34 \%$ of the Top 100 titles did not make their EULAs available before a consumer engaged in a transaction. See supra notes 11-12 and accompanying text.

75 Certain warranty disclaimers must be conspicuous under Article 2 of the UCC. See, e.g., U.C.C. \$ 2-316 (1998). 
Further the "I agree" icon must be adjacent to or at the end of the standard form, and must automatically appear on the screen or in a scroll-down window as part of the processing of the transaction. A mere reference to terms that can be found elsewhere ("browsewrap") should not suffice. ${ }^{76}$

The Federal Trade Commission's "truth-in-advertising" and "dot com disclosures" policies should supplement the disclosure strategies discussed here. ${ }^{77}$ These call for truthful and non-deceptive advertising and "clear and conspicuous" disclosures. However, contract law should not consider the FTC approach alone a solution to the e-express warranty and disclaimer problem. For all of the reasons agencies, as a general matter, are imperfect solutions to society's problems, such as agency capture, lack of resources, and ineffective policing, we believe that contract law should itself address the problem of e-warranties and disclaimers.

What will be the effect of the disclosure measures we suggest? Disclosure will increase the opportunity for consumers to uncover warranty disclaimers. But for the reasons discussed in Part II and for the reasons that follow, we doubt that disclosure will greatly increase reading of any terms of an e-standard form, including warranty disclaimers. We will suggest, however, that disclosure may be the best of a series of less-than satisfactory solutions.

Research on advertising and on shopping behavior on the Internet reinforces the conclusion that greater disclosure of e-standard terms will have little influence on consumers' purchasing strategies, especially because of the proximity of the warranties to the "I agree" icon that commits a consumer to a transaction. In an earlier article, Hillman reported on a study that identifies two kinds of Internet shoppers. ${ }^{78}$ The "convenience" shopper rationally uses the Internet to search for a particular product or service and to compare prices and quality reports. ${ }^{79}$ The "recreational" shopper, as the name implies, shops for fun and commonly purchases impulsively. ${ }^{80}$ Recreational shoppers "may be driven by need to purchase rather than need for a

${ }^{76}$ For a discussion of clickwrap and browsewrap forms of acceptance, see ALI PRINCIPLES, supra note $1, \S 2.01, \mathrm{cmt} . \mathrm{b} ; i d . \S 2.02, \mathrm{cmt}$. b; and $i d$. at 150-56.

77 See Federal Trade Commission, Frequently Asked Advertising Questions: A Guide for Small Business, http://www.ftc.gov/bcp/edu/pubs/business/ adv/bus35.shtm (last visited Nov. 24, 2008).

${ }^{78}$ Robert A. Hillman, Online Boilerplate: Would Mandatory Website Disclosure of E-Standard Terms Backfire?, 104 MICH. L. REV. 837, 851 (2006) (discussing Junghyun Kim \& Robert LaRose, Interactive E-Commerce: Promoting Consumer Efficiency or Impulsivity?, 10 J. OF COMPUTER-MEDIATED COMM. (Nov. 2004), available at $\mathrm{http} / / \mathrm{jcmc}$.indiana.edu/vollo/issuel/kim_larose.html).

${ }^{79}$ Kim \& LaRose, supra note 78.

${ }^{80}$ Id. 
product." 81 The Internet likely promotes impulsive purchasing because it supplies "recreational shopping features," such as "email alerts of new products and special offers" twenty-four hours a day. ${ }^{82}$ In addition, people who purchase impulsively prefer the privacy eshopping affords. ${ }^{83}$ In fact, shoppers who start an Internet search for convenience may ultimately purchase impulsively. ${ }^{84}$ Ironically, the lack of a live agent exerting time pressure on consumers actually may reduce the tendency to read terms and increase impulsive purchasing. Consumers with time to interact with a website may gain confidence in and form a favorable impression of it. ${ }^{85}$ Such an attitude may reinforce the belief that reading terms would be a waste of time. ${ }^{86}$

The opportunity to commit to a purchase literally seconds after reading a licensor's promises and representations that are carefully designed to induce purchasing obviously further promotes and facilitates impulsive purchasing. ${ }^{87}$ In short, the Internet environment likely is not one in which we can hope for careful perusal of warranty disclaimers even with greater disclosure. ${ }^{88}$

In addition to our qualms about the effects of disclosure on

81 Id. (citing Dennis W. Rook \& Robert J. Fisher, Normative Influences in Impulsive Buying Behavior, 22 J. OF CONSUMER RES. 305-13 (1995)).

82 Id. See also Xiaoni Shang, Victor R. Prybutok, \& Chang E. Koh, The Role of Impulsiveness in a TAM-Based Online Purchasing Behavior Model, in InNOVATIVE TECHNOLOGIES FOR INFORMation Resource Management 334, 335 (Mehdi Khosrow-Pour ed., 2008) ("The development of the digital economy makes impulsive purchasing even more convenient and pervasive. . . Online vendors are convinced that a substantial portion of their sales is attributed to impulse purchases. . . Impulsive purchasing is bound to increase as the Internet makes it easier for consumers to access a wide range of brands and to compare different products without ever leaving home.").

83 Kim and LaRose, supra note 78.

84 Id.

85 See Miriam J. Metzger, Privacy, Trust, and Disclosure: Exploring Barriers to Electronic Commerce, 9 J. COMPUTER-MEDIATED COMM. (July 2004), available at http://jcmc.indiana.edu/vol9/issue4/metzger.html ("Web sites of respected organizations that were visually pleasing were rated high in trustworthiness and expertise.").

${ }^{86}$ Kim \& LaRose, supra note 78 (citing Sharon E. Beatty \& M. Elizabeth Ferrell, Impulse Buying: Modeling Its Precursors, 74 J. OF RETAILING 169 (1998)).

87 The more formalities and processes required to make a commitment, the more likely a party will be cautioned about the seriousness of what she is doing. See Lon L. Fuller, Consideration and Form, 41 COLUM. L. REV. 799, 799-802 (1941).

${ }^{88}$ Hillman's survey of first-year law students reported that 15 out of 92 respondents read warranty terms. See Hillman, Survey, supra note 36, at 308 n.30. But see Chang-Hoan Cho, Jaewon Kang, \& Hongsik John Cheon, Online Shopping Hesitation, 9 CYBERPSYCHOL. \& BEHAVIOR 261 (2006). 
consumer reading of terms, we have another concern. Ironically, more disclosure may only mean more judicial enforcement of edisclaimers because consumers will be unable to claim surprise if the disclaimer is readily available for their perusal. ${ }^{89}$ Perhaps watchdog groups will become more efficacious once e-standard forms are more readily available for perusal, thereby tipping the balance in favor of greater disclosure despite our concern, but only time will tell.

In light of these realities, we should not rule out other methods of dealing with e-warranty disclaimers, some involving even greater disclosure requirements. For example, the law could require that consumers click "I agree" at the end of each e-disclaimer (and other contentious terms) or that disclaimers must be in bold print to emphasize their importance. ${ }^{90}$ However, critics may claim, with some justification, that extra clicking would be cumbersome for little gain because consumers would simply click without digesting the disclaimer. Nor has bold or large print worked very well in the paper world. ${ }^{91}$

Another method of dealing with the warranty/disclaimer problem would be to require conspicuous notice on the website, both in terms of placement and size, that representations and promises made there are not legally enforceable. We have already mentioned that fifty-one of the fifty-four titles in our data contain website "terms of use" that appear to disclaim website express warranties, but that these are not enforceable because of the absence of sufficient notice of the terms of use and their lack of real acceptance by consumers. ${ }^{92}$ However, if a licensor gave ample notice, for example, by including a conspicuous preamble on the website stating that nothing that follows is legally enforceable, reasonable consumers would not rely on any representations or promises and therefore contract law would not recognize any express warranties in the first place. The problem with this approach is that it ties the hands of good-faith licensors who want to advertise their products by requiring them to send perhaps misleading signals about the quality of their products: "We assume no legal liability, but our software will allow you to run Windows on your Mac" suggests that this licensor has little faith in its product or its promises. Perhaps requiring licensors to highlight their warranty disclaimers in a window that automatically appears before the completion of a transaction would alleviate this problem, but it is hard to justify why warranty disclaimers deserve more attention than

\footnotetext{
${ }^{89}$ Hillman, supra note 78 , at 853-55.

90 See id.

91 Analogous strategies in the paper world have not been very successful, in part because consumers are unlikely to be riveted to attention by such formalities.

92 See supra notes 16-17 and accompanying text.
} 
other potentially "dangerous" terms, such as those authorizing automatic renewal or unilateral modification. Contract law could require licensors to include all potentially material terms in a pop-up window before a consumer can commit to a transaction, but sorting out what to include would challenge licensors and courts. Further, with clickwrap disclosure of the entire EULA already required, additional disclosure may be confusing and deter any reading at all. On the other hand, warranty disclaimers in EULAs particularly rankle because they take back commitment-inducing promises and representations affirmatively set forth on the website. Perhaps a popup window solely consisting of disclaimers is therefore justified.

Still another approach to the warranty/disclaimer problem would be to invalidate all e-disclaimers of express warranties regardless of the context on the theory that such disclaimers are invariably unexpected and misleading and therefore unconscionable. This strategy would deal a considerable blow to freedom of contract and related policies discussed above for enforcing disclaimers. ${ }^{93}$ And, so long as the disclosure process is reasonable, it is difficult to make a case for wholesale exclusion of disclaimers notwithstanding consumers' seeming inability to protect themselves. In short, unconscionability per se may be too blunderbuss a remedy for the warranty/disclaimer problem. Disclosure, incorporating some or all of the ideas we have suggested, may be the best of a series of imperfect solutions, as we now discuss briefly in the conclusion.

\section{Conclusion}

We believe that e-commerce exacerbates the problem of warranties and disclaimers and that lawmakers should address this issue. And we find that more disclosure is the best of various imperfect solutions to the problem. Disclosure is inexpensive and, at minimum, creates the potential for more legitimate consumer assent to e-standard forms, including assent to disclaimers of warranty. Even if in the short term consumers do not read their forms, perhaps consumers will eventually learn of misleading warranties. After all, the Internet creates communication possibilities and research tools unavailable to disgruntled purchasers in the paper world. Only a few readers or vitalized watchdog groups may suffice to spread the word. The prospect of the word getting out that a licensor does not intend to stand behind its promises and representations may be sufficient to

93 See supra text accompanying notes 39-41. 
curtail the practice of misleading warranties and disclaimers. 
APPENDIX 1

\begin{tabular}{|c|c|c|c|c|c|c|}
\hline $\begin{array}{l}\text { Sales } \\
\text { Rank }\end{array}$ & Developer & \begin{tabular}{|l|} 
Software \\
Title
\end{tabular} & \begin{tabular}{|l|} 
Website \\
Address \\
(last visited \\
Dec. 12, \\
2008, unless \\
otherwise \\
noted)
\end{tabular} & $\begin{array}{l}\text { Example of } \\
\text { Express } \\
\text { Warranty } \\
\text { created on } \\
\text { website }\end{array}$ & Disclaimer Language & $\begin{array}{ll}\text { Limited } & \text { Warranty } \\
\text { Language } & \end{array}$ \\
\hline 1 & Apple & \begin{tabular}{|l|} 
Apple \\
Mac OS X \\
Version \\
10.5 \\
Leopard
\end{tabular} & $\begin{array}{l}\text { http://www.a } \\
\text { pple.com/ma } \\
\text { cosx/features } \\
/\end{array}$ & $\begin{array}{l}\text { Run Windows } \\
\text { on your Mac. }\end{array}$ & 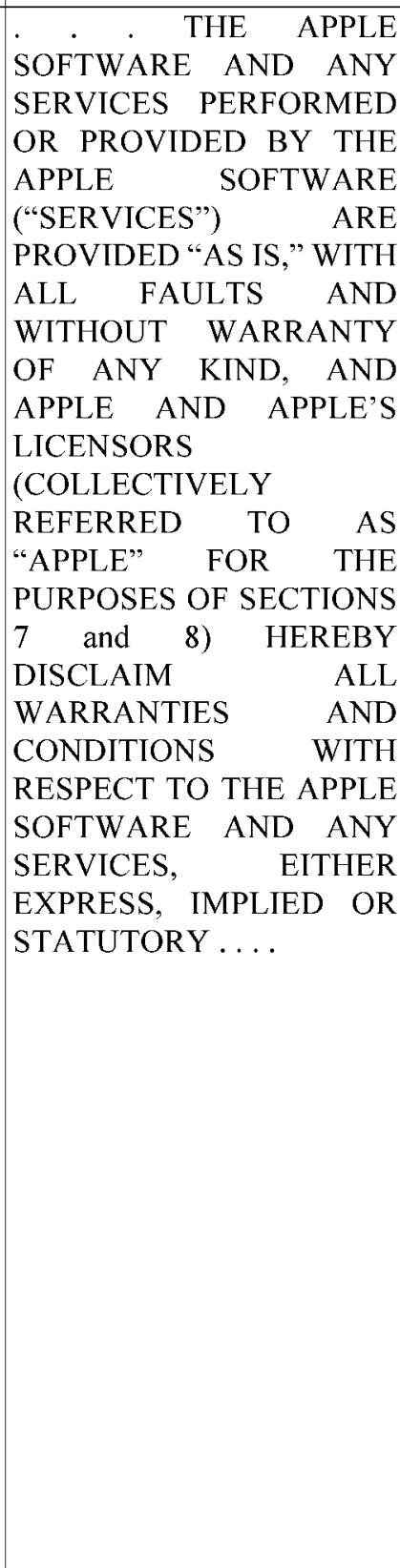 & $\begin{array}{l}\text { Limited Warranty on Media. } \\
\text { Apple warrants the media on } \\
\text { which the Apple Software is } \\
\text { recorded and delivered by } \\
\text { Apple to be free from defects in } \\
\text { materials and workmanship } \\
\text { under normal use for a period of } \\
\text { ninety (90) days from the date } \\
\text { of original retail purchase. Your } \\
\text { exclusive remedy under this } \\
\text { Section shall be, at Apple's } \\
\text { option, a refund of the purchase } \\
\text { price of the product containing } \\
\text { the Apple Software or } \\
\text { replacement of the Apple } \\
\text { Software which is returned to } \\
\text { Apple or an Apple authorized } \\
\text { representative with a copy of } \\
\text { the receipt. THIS LIMITED } \\
\text { WARRANTY AND ANY } \\
\text { IMPLIED WARRANTIES ON } \\
\text { THE MEDIA INCLUDING, } \\
\text { BUT NOT LIMITED TO, THE } \\
\text { IMPLIED WARRANTIES OF } \\
\text { MERCHANTABILITY, OF } \\
\text { SATISFACTORY QUALITY, } \\
\text { AND OF FITNESS FOR A } \\
\text { PARTICULAR PURPOSE, } \\
\text { ARE LIMITED IN } \\
\text { DURATION TONINETY (90) } \\
\text { DAYS FROM THE DATE OF } \\
\text { ORIGINAL RETAIL } \\
\text { PURCHASE...THE LIMITED } \\
\text { WARRANTY SET FORTH } \\
\text { HEREIN IS THE ONLY } \\
\text { WARRANTY MADE TO YOU } \\
\text { AND IS PROVIDED IN LIEU } \\
\text { OF ANY OTHER } \\
\text { WARRANTIES (IF ANY) } \\
\text { CREATED BY ANY } \\
\text { DOCUMENTATION, } \\
\text { PACKAGING OR } \\
\text { OTHERWISE. }\end{array}$ \\
\hline
\end{tabular}




\begin{tabular}{|c|c|c|c|c|c|c|}
\hline 2 & Microsoft & \begin{tabular}{|l|} 
Microsoft \\
Office \\
Home and \\
Student \\
2007
\end{tabular} & $\begin{array}{l}\text { http://office. } \\
\text { microsoft.co } \\
\text { m/en- } \\
\text { us/suites/HA } \\
1016551510 \\
33 . a s p x\end{array}$ & $\begin{array}{l}\text { New support } \\
\text { for Portable } \\
\text { Document } \\
\text { Format (PDF) } \\
\text { and XML } \\
\text { Paper } \\
\text { Specification } \\
\text { (XPS) file } \\
\text { formats helps } \\
\text { ensure broader } \\
\text { distribution of } \\
\text { your } \\
\text { documents } \\
\text { with others. }\end{array}$ & $\begin{array}{|lr|}\text { NO } & \text { OTHER } \\
\text { WARRANTIES. } & \text { THE } \\
\text { LIMITED WARRANTY IS } \\
\text { THE ONLY } & \text { DIRECT } \\
\text { WARRANTY } & \text { FROM } \\
\text { MICROSOFT. MICROSOFT } \\
\text { GIVES NO } & \text { OTHER } \\
\text { EXPRESS } & \text { WARRANTIES, } \\
\text { EUUARANTEES } & \text { OR } \\
\text { GONDITIONS. } & \\
\end{array}$ & $\begin{array}{l}\text { LIMITED WARRANTY. If } \\
\text { you follow the instructions, } \\
\text { the software will perform } \\
\text { substantially as described in } \\
\text { the Microsoft materials that } \\
\text { you receive in or with the } \\
\text { software. }\end{array}$ \\
\hline 4 & Microsoft & $\begin{array}{l}\text { Microsoft } \\
\text { Office } \\
2004 \text { for } \\
\text { Mac } \\
\text { Student } \\
\text { and } \\
\text { Teacher }\end{array}$ & $\begin{array}{l}\text { No Longer } \\
\text { available on } \\
\text { Microsoft.co } \\
\mathrm{m}\end{array}$ & $\begin{array}{l}\text { Now you can } \\
\text { take full } \\
\text { advantage of } \\
\text { the Spotlight } \\
\text { search } \\
\text { functionality } \\
\text { in Mac OS X } \\
\text { Tiger with the } \\
\text { help of Office } \\
\text { Update 11.2.3. }\end{array}$ & $\begin{array}{l}\text { The Limited Warranty that } \\
\text { appears above is the only } \\
\text { express warranty made to you } \\
\text { and is provided in lieu of any } \\
\text { other express warranties or } \\
\text { similar obligations (if any) } \\
\text { created by any advertising, } \\
\text { documentation, packaging, or } \\
\text { other communications. } \\
\text { Except for the Limited } \\
\text { Warranty and to the } \\
\text { maximum extent permitted } \\
\text { by applicable law, Microsoft } \\
\text { and its suppliers provide the } \\
\text { Software and support services } \\
\text { (if any) AS IS AND WITH } \\
\text { ALL FAULTS, and hereby } \\
\text { disclaim all other warranties } \\
\text { and conditions, whether } \\
\text { express, implied or statutory. }\end{array}$ & $\begin{array}{l}\text { Microsoft warrants that the } \\
\text { Software will perform } \\
\text { substantially in accordance } \\
\text { with the accompanying } \\
\text { materials for a period of } \\
\text { ninety (90) days from the date } \\
\text { of receipt. Any supplements or } \\
\text { updates to the Software, } \\
\text { including without limitation, } \\
\text { any (if any) service packs or } \\
\text { hot fixes provided to you after } \\
\text { the expiration of the ninety } \\
\text { day Limited Warranty period } \\
\text { are not covered by any } \\
\text { warranty or condition, } \\
\text { express, implied or statutory. }\end{array}$ \\
\hline
\end{tabular}




\begin{tabular}{|c|c|c|c|c|c|c|}
\hline 5 & Intuit & $\mid$\begin{tabular}{lr}
\multicolumn{2}{|c|}{ Quickboo } \\
ks & Pro \\
2008 &
\end{tabular} & $\begin{array}{l}\text { http://quickb } \\
\text { ooks.intuit.c } \\
\text { om/product/ } \\
\text { accounting- } \\
\text { software/sm } \\
\text { all-business- } \\
\text { accounting- } \\
\text { software.jht } \\
\text { ml } \\
\text { (last visited } \\
\text { Mar. 31, } \\
\text { 2008) }\end{array}$ & \begin{tabular}{|l} 
Download \\
credit card and \\
bank \\
transactions. \\
\end{tabular} & 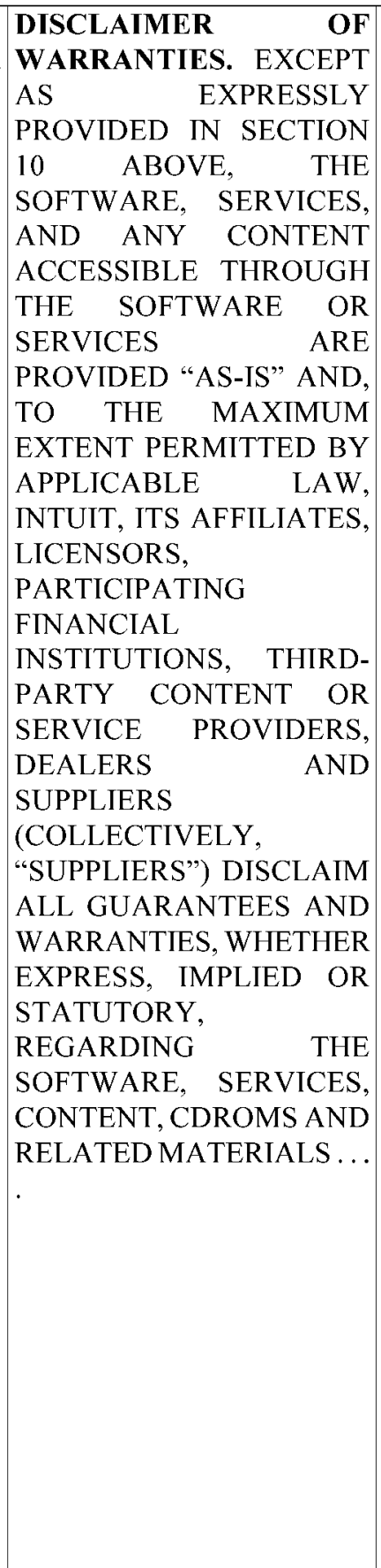 & $\begin{array}{l}\text { 10. SATISFACTION } \\
\text { GUARANTEED/LIMITED } \\
\text { WARRANTY. (i) } \\
\text { Satisfaction Guarantee. If you } \\
\text { are not satisfied with the } \\
\text { Software and (a) You } \\
\text { purchased the Software from a } \\
\text { retail store, you may uninstall } \\
\text { and delete all copies of the } \\
\text { Software from your } \\
\text { computer(s) and return it } \\
\text { within 60 days of purchase to } \\
\text { the store where you purchased } \\
\text { your license with a dated } \\
\text { receipt for a full refund. If the } \\
\text { store is unable or unwilling to } \\
\text { issue a refund or you obtained } \\
\text { the Software directly from } \\
\text { Intuit, you may uninstall and } \\
\text { delete all copies of the } \\
\text { Software and return the } \\
\text { Software with a dated receipt } \\
\text { or packing slip within } 60 \text { days } \\
\text { of purchase via U.S. mail to } \\
\text { Intuit Inc., Returns } \\
\text { Department, PO Box 190004, } \\
\text { Greenville, SC } 29390-9004 \text { or } \\
\text { via UPS to Intuit Inc., Returns } \\
\text { Department, } 110 \text { Hidden Lake } \\
\text { Circle, Duncan, SC } 29334 . . . \\
\text { (ii) Limited Warranty. (a) If } \\
\text { the CDROM on which the } \\
\text { Software is stored is defective, } \\
\text { then return the CDROM to } \\
\text { Intuit Inc., Returns } \\
\text { Department, PO Box 19004, } \\
\text { Greenville, SC 29390-9004 } \\
\text { within 60 days of shipment (or } \\
\text { in the case of a retail purchase, } \\
\text { within 60 days of purchase) } \\
\text { with a dated receipt or packing } \\
\text { slip, and a replacement } \\
\text { CDROM will be mailed to } \\
\text { you ... }\end{array}$ \\
\hline
\end{tabular}




\begin{tabular}{|c|c|c|c|c|c|c|}
\hline 6 & Adobe & \begin{tabular}{|l} 
Adobe \\
Photoshop \\
Elements \\
6
\end{tabular} & $\begin{array}{l}\text { http://Www.a } \\
\text { dobe.com/pr } \\
\text { oducts/photo } \\
\text { shopelwin/u } \\
\text { pgrade/?pro } \\
\text { moid=BGR } \\
\text { WA } \\
\text { (last visited } \\
\text { Mar. 31, } \\
\text { 2008) }\end{array}$ & $\begin{array}{l}\text { Photoshop } \\
\text { Elements } \\
\text { eliminates red } \\
\text { eye } \\
\text { automatically } \\
\text { as you } \\
\text { download } \\
\text { photos from } \\
\text { your camera. }\end{array}$ & $\begin{array}{l}\ldots \text { the Software and access } \\
\text { to any websites, online } \\
\text { services and CD Services as- } \\
\text { is and with all faults and } \\
\text { expressly disclaim all other } \\
\text { warranties, conditions, } \\
\text { representations or terms, } \\
\text { express or implied, whether } \\
\text { by statute, common law, } \\
\text { custom, usage or otherwise.. } \\
\text {. }\end{array}$ & $\begin{array}{l}\text { 6. LIMITED WARRANTY. } \\
\text { Except as may be otherwise } \\
\text { provided in Section } 14 \text {, Adobe } \\
\text { warrants to the individual or } \\
\text { entity that first purchases a } \\
\text { license for the Software for } \\
\text { use pursuant to the terms of } \\
\text { this agreement that the } \\
\text { Software will perform } \\
\text { substantially in accordance } \\
\text { with the Documentation for } \\
\text { the ninety (90) day period } \\
\text { following receipt of the } \\
\text { Software when used on the } \\
\text { recommended operating } \\
\text { system and hardware } \\
\text { configuration. Non-substantial } \\
\text { variation of performance from } \\
\text { the Documentation does not } \\
\text { establish a warranty right. }\end{array}$ \\
\hline
\end{tabular}




\begin{tabular}{|c|c|c|c|c|c|c|}
\hline 8 & Apple & \begin{tabular}{|l} 
Apple \\
iLife 08
\end{tabular} & $\begin{array}{l}\text { http://Www.s } \\
\text { tore.apple.co } \\
\text { m/us/product } \\
\text { /MB615Z/A } \\
\text { ?fnode=MT } \\
\text { Y1NDAzOA } \\
\text { \&mco=MjM } \\
\text { 0MzU5Mw }\end{array}$ & $\begin{array}{l}\text { Import from } \\
\text { popular video } \\
\text { devices } \\
\text { including } \\
\text { AVCHD. } \\
\end{array}$ & 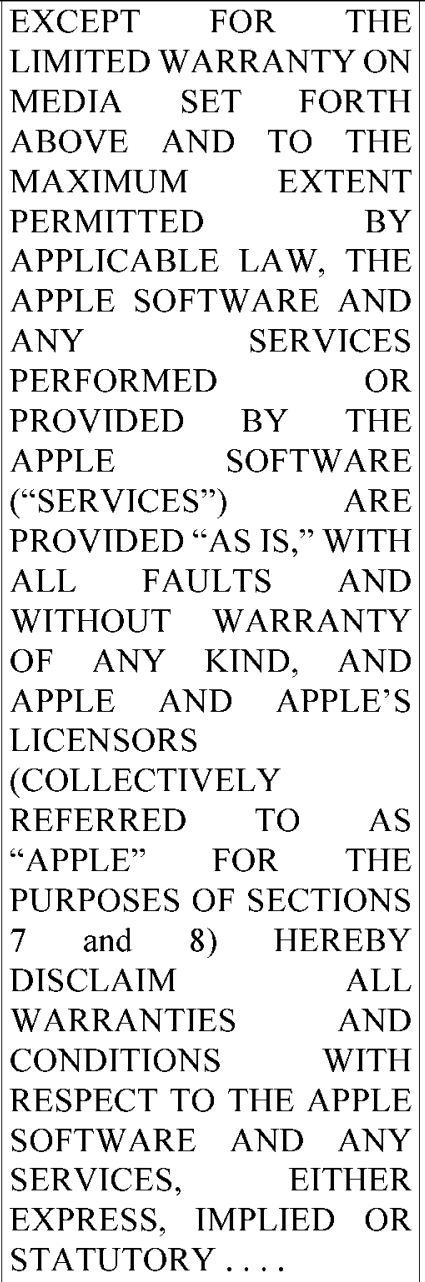 & $\begin{array}{l}\text { 6. Limited Warranty on } \\
\text { Media. Apple warrants the } \\
\text { media on which the Apple } \\
\text { Software is recorded and } \\
\text { delivered by Apple to be free } \\
\text { from defects in materials and } \\
\text { workmanship under normal } \\
\text { use for a period of ninety }(90) \\
\text { days from the date of original } \\
\text { retail purchase. }\end{array}$ \\
\hline
\end{tabular}




\begin{tabular}{|c|c|c|c|c|c|c|}
\hline 9 & Symantec & \begin{tabular}{|l|} 
Norton \\
Internet \\
Security \\
2008 up to \\
3 Users
\end{tabular} & $\begin{array}{l}\text { http://www.s } \\
\text { ymantec.co } \\
\text { m/norton/pro } \\
\text { ducts/overvi } \\
\text { ew.jsp?pcid } \\
\text { =is\&pvid=ni } \\
\text { s2008 } \\
\text { (last visited } \\
\text { Mar. 31, } \\
2008)\end{array}$ & $\begin{array}{l}\text { Blocks } \\
\text { identity theft } \\
\text { by phishing } \\
\text { Web sites. }\end{array}$ & $\begin{array}{l}\text { TO THE MAXIMUM } \\
\text { EXTENT PERMITTED BY } \\
\text { APPLICABLE LAW, THE } \\
\text { ABOVE WARRANTY IS } \\
\text { EXCLUSIVE AND IN LIEU } \\
\text { OF ALL OTHER } \\
\text { WARRANTIES, WHETHER } \\
\text { EXPRESS OR IMPLIED ... }\end{array}$ & $\begin{array}{l}\text { 6. Limited Warranty: } \\
\text { Symantec warrants that the } \\
\text { media on which the Software } \\
\text { is distributed will be free from } \\
\text { defects for a period of sixty } \\
\text { (60) days from the date of } \\
\text { delivery of the Software to } \\
\text { You. Your sole remedy in the } \\
\text { event of a breach of this } \\
\text { warranty will be that } \\
\text { Symantec will, at its option, } \\
\text { replace any defective media } \\
\text { returned to Symantec within } \\
\text { the warranty period or refund } \\
\text { the money You paid for the } \\
\text { Software. Symantec does not } \\
\text { warrant that the Software will } \\
\text { meet Your requirements or } \\
\text { that operation of the Software } \\
\text { will be uninterrupted or that } \\
\text { the Software will be error- } \\
\text { free. }\end{array}$ \\
\hline
\end{tabular}




\begin{tabular}{|c|c|c|c|c|c|c|}
\hline 11 & Intuit & \begin{tabular}{|l|} 
Quicken \\
2008 \\
Deluxe
\end{tabular} & $\begin{array}{l}\text { http://quicke } \\
\text { n.intuit.com/ } \\
\text { personal- } \\
\text { finance/delu } \\
\text { xe-money- } \\
\text { management } \\
\text {.jhtml } \\
\text { (last visited } \\
\text { Mar. } 31 \text {, } \\
\text { 2008) }\end{array}$ & $\begin{array}{l}\text { Quicken } \\
\text { Deluxe also } \\
\text { exports your } \\
\text { data directly } \\
\text { to TurboTax, } \\
\text { so you won't } \\
\text { have to re- } \\
\text { enter the same } \\
\text { information } \\
\text { twice. }\end{array}$ & \begin{tabular}{lr}
. DISCLAIM & ALL \\
GUARANTEES & AND \\
\multicolumn{2}{l}{ WARRANTIES, WHETHER } \\
EXPRESS, IMPLIED OR \\
STATUTORY, \\
REGARDING \\
SOFTWARE. FURTHER, THE \\
INTUIT DOES NOT \\
WARRANT ACCESS TO \\
THE INTERNET OR TO \\
ANY OTHER SERVICE OR \\
CONTENT OR DATA \\
THROUGH \\
SOFTWARE ....
\end{tabular} & $\begin{array}{l}9 . \text { SATISFACTION } \\
\text { GUARANTEED. If you are } \\
\text { not satisfied with the Software } \\
\text { and (a) You purchased the } \\
\text { Software from a retail store, } \\
\text { you may uninstall and delete } \\
\text { all copies of the Software } \\
\text { from your computer(s) and } \\
\text { return it within } 60 \text { days of } \\
\text { purchase to the store where } \\
\text { you purchased your license } \\
\text { with a dated receipt for a full } \\
\text { refund. If the store is unable or } \\
\text { unwilling to issue a refund or } \\
\text { you obtained the Software } \\
\text { directly from Intuit, you may } \\
\text { uninstall and delete all copies } \\
\text { of the Software and return the } \\
\text { Software with a dated receipt } \\
\text { or packing slip within } 60 \text { days } \\
\text { of purchase via U.S. mail to } \\
\text { Intuit Inc., Returns } \\
\text { Department, PO Box } 190004, \\
\text { Greenville, SC } 29390-9004 \text { or } \\
\text { via UPS to Intuit Inc., Returns } \\
\text { Department, } 110 \text { Hidden Lake } \\
\text { Circle, Duncan, SC } 29334 \text {. (b) } \\
\text { You obtained the Software } \\
\text { directly from Intuit via an } \\
\text { Internet download, you may } \\
\text { submit a written request to } \\
\text { Intuit including your name, } \\
\text { contact and product order } \\
\text { information to Intuit Inc., } \\
\text { Returns Department, PO Box } \\
\text { 19004, Greenville, SC } 29390- \\
9004 .\end{array}$ \\
\hline
\end{tabular}




\begin{tabular}{|c|c|c|c|c|c|c|}
\hline 12 & Apple & \begin{tabular}{|l|} 
Apple \\
iWork '08
\end{tabular} & $\begin{array}{l}\text { http://store.a } \\
\text { pple.com/us/ } \\
\text { product/MB } \\
624 Z / A ? \text { fno } \\
\text { de=MTY1N } \\
\text { DAzOA\&m } \\
\text { co=MjQzNz } \\
\text { kxNQ }\end{array}$ & $\begin{array}{l}\text { Import from } \\
\text { and export to } \\
\text { Microsoft } \\
\text { Excel and } \\
\text { other formats. }\end{array}$ & 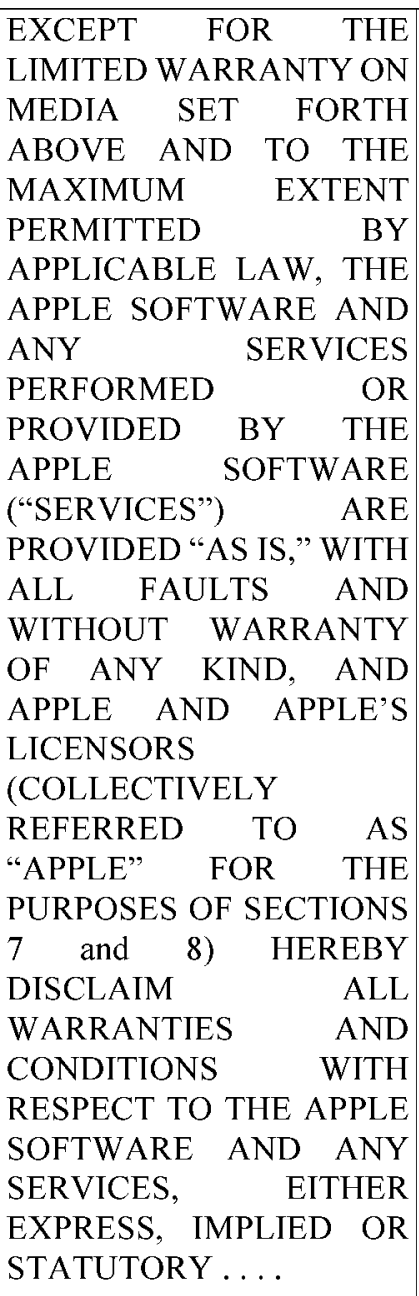 & $\begin{array}{l}\text { 6. Limited Warranty on } \\
\text { Media. Apple warrants the } \\
\text { media on which the Apple } \\
\text { Software is recorded and } \\
\text { delivered by Apple to be free } \\
\text { from defects in materials and } \\
\text { workmanship under normal } \\
\text { use for a period of ninety }(90) \\
\text { days from the date of original } \\
\text { retail purchase. }\end{array}$ \\
\hline 13 & $\begin{array}{l}\text { Nova } \\
\text { Developme } \\
\text { nt }\end{array}$ & $\begin{array}{l}\text { Parallels } \\
\text { Desktop } \\
\begin{array}{ll}3.0 \quad \text { for } \\
\text { Mac }\end{array}\end{array}$ & $\begin{array}{l}\text { http://www. } \\
\text { novadevelop } \\
\text { ment.com/Pr } \\
\text { oducts/Parall } \\
\text { els_Desktop } \\
\text { 3/default.as } \\
\text { px }\end{array}$ & $\begin{array}{l}\text { With } \\
\text { Parallels' } \\
\text { award- } \\
\text { winning } \\
\text { virtualization } \\
\text { technology, } \\
\text { you can run } \\
\text { Mac OS X } \\
\text { and your } \\
\text { favorite } \\
\text { Windows } \\
\text { applications at } \\
\text { the same time. } \\
\text { You can even } \\
\text { drag-and-drop } \\
\text { files between } \\
\text { desktops! }\end{array}$ & $\begin{array}{l}\text { WITH THE } \text { EXCEPTION } \\
\text { OF THE FOREGOING } \\
\text { EXPRESS WARRANTY, } \\
\text { THE SOFTWARE IS } \\
\text { LICENSED “AS IS," AND } \\
\text { PARALLELS DISCLAIMS } \\
\text { ANY AND ALL OTHER } \\
\text { WARRANTIES, WHETHER } \\
\text { EXPRESS OR IMPLIED ... }\end{array}$ & 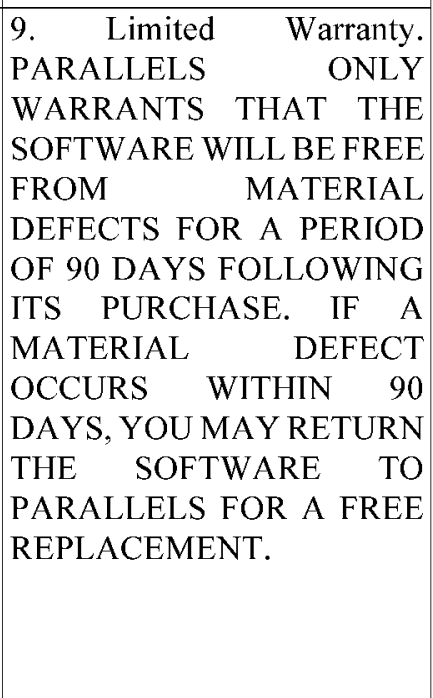 \\
\hline
\end{tabular}


Warranties And Disclaimers in the Electronic AgE

\begin{tabular}{|c|c|c|c|c|c|c|}
\hline 15 & Microsoft & \begin{tabular}{|l} 
Microsoft \\
Outlook \\
2007
\end{tabular} & $\begin{array}{l}\text { http://office. } \\
\text { microsoft.co } \\
\text { m/en- } \\
\text { us/outlook/H } \\
\text { A101650261 } \\
\text { 033.aspx }\end{array}$ & \begin{tabular}{|l|} 
Outlook \\
Mobile \\
Service is a \\
feature of \\
Outlook that \\
enables you to \\
send r and \\
receive text \\
and picture \\
messages \\
between \\
Officer \\
Outlook 2007 \\
and any \\
mobile phone.
\end{tabular} & $\begin{array}{lr}\text { NO } & \text { OTHER } \\
\text { WARRANTIES. } & \text { THE } \\
\text { LIMITED WARRANTY IS } \\
\text { THE ONLY DIRECT } \\
\text { WARRANTY } \\
\text { MICROSOFT. MICROSOM } \\
\text { GIVES NO OTHER } \\
\text { EXPRESS WARRANTIES, } \\
\text { GUARANTEES } \\
\text { CONDITIONS. OR }\end{array}$ & $\begin{array}{l}\text { LIMITED WARRANTY. If } \\
\text { you follow the instructions, } \\
\text { the software will perform } \\
\text { substantially as described in } \\
\text { the Microsoft materials that } \\
\text { you receive in or with the } \\
\text { software. }\end{array}$ \\
\hline
\end{tabular}




\begin{tabular}{|c|c|c|c|c|c|c|}
\hline 19 & Microsoft & $\begin{array}{l}\text { Microsoft } \\
\text { Office } \\
2004 \text { for } \\
\text { Mac } \\
\text { Standard }\end{array}$ & $\begin{array}{l}\text { http://www. } \\
\text { microsoft.co } \\
\mathrm{m} / \mathrm{mac} / \mathrm{prod} \\
\text { ucts/office20 } \\
04 . \mathrm{mspx}\end{array}$ & $\begin{array}{l}\text { Manage your } \\
\text { projects more } \\
\text { efficiently by } \\
\text { accessing all } \\
\text { of your } \\
\text { project-related } \\
\text { e-mail } \\
\text { messages, } \\
\text { files, notes, } \\
\text { contacts, and } \\
\text { schedules in } \\
\text { one } \\
\text { convenient } \\
\text { place. }\end{array}$ & 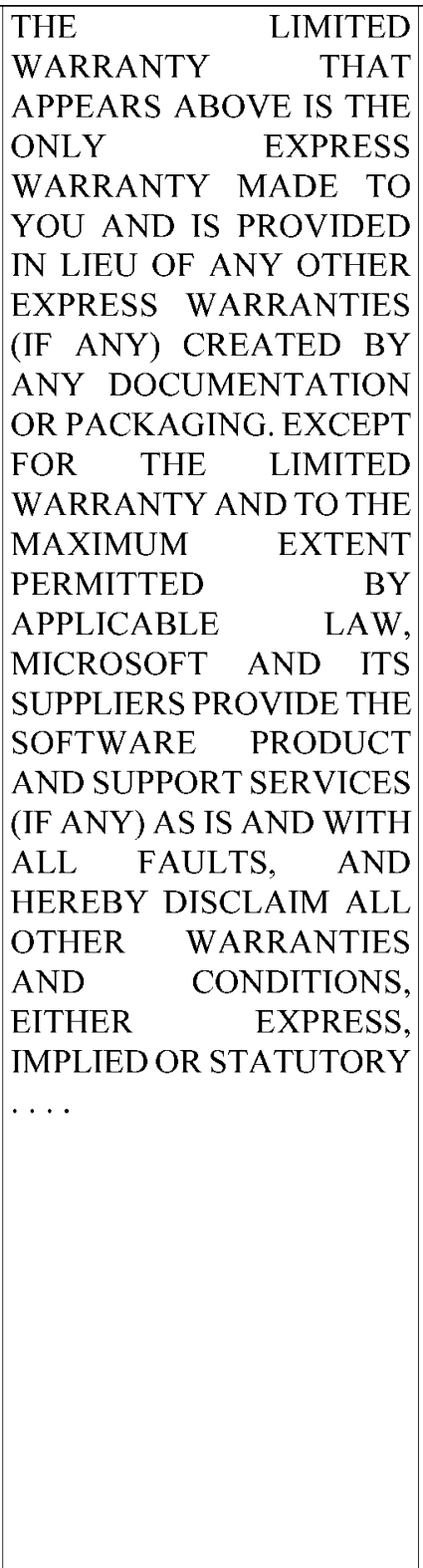 & $\begin{array}{l}\text { 20. LIMITED WARRANTY } \\
\text { FOR SOFTWARE } \\
\text { PRODUCTS ACQUIRED IN } \\
\text { THE US AND CANADA. } \\
\text { Microsoft warrants that the } \\
\text { SOFTWARE PRODUCT will } \\
\text { perform substantially in } \\
\text { accordance with the } \\
\text { accompanying materials for a } \\
\text { period of ninety (90) days } \\
\text { from the date of receipt. If an } \\
\text { implied warranty or condition } \\
\text { is created by your } \\
\text { state/jurisdiction and federal } \\
\text { or state/provincial law } \\
\text { prohibits disclaimer of it, you } \\
\text { also have an implied warranty } \\
\text { or condition, BUT ONLY AS } \\
\text { TO DEFECTS } \\
\text { DISCOVERED DURING } \\
\text { THE PERIOD OF THIS } \\
\text { LIMITED WARRANTY } \\
\text { (NINETY DAYS). AS TO } \\
\text { ANY DEFECTS } \\
\text { DISCOVERED AFTER THE } \\
\text { NINETY (90) DAY PERIOD, } \\
\text { THERE IS NO WARRANTY } \\
\text { OR CONDITION OF ANY } \\
\text { KIND. . Any supplements } \\
\text { or updates to the SOFTWARE } \\
\text { PRODUCT, including without } \\
\text { limitation, any (if any) service } \\
\text { packs or hot fixes provided to } \\
\text { you after the expiration of the } \\
\text { ninety (90) day Limited } \\
\text { Warranty period are not } \\
\text { covered by any warranty or } \\
\text { condition, express, implied or } \\
\text { statutory. }\end{array}$ \\
\hline
\end{tabular}




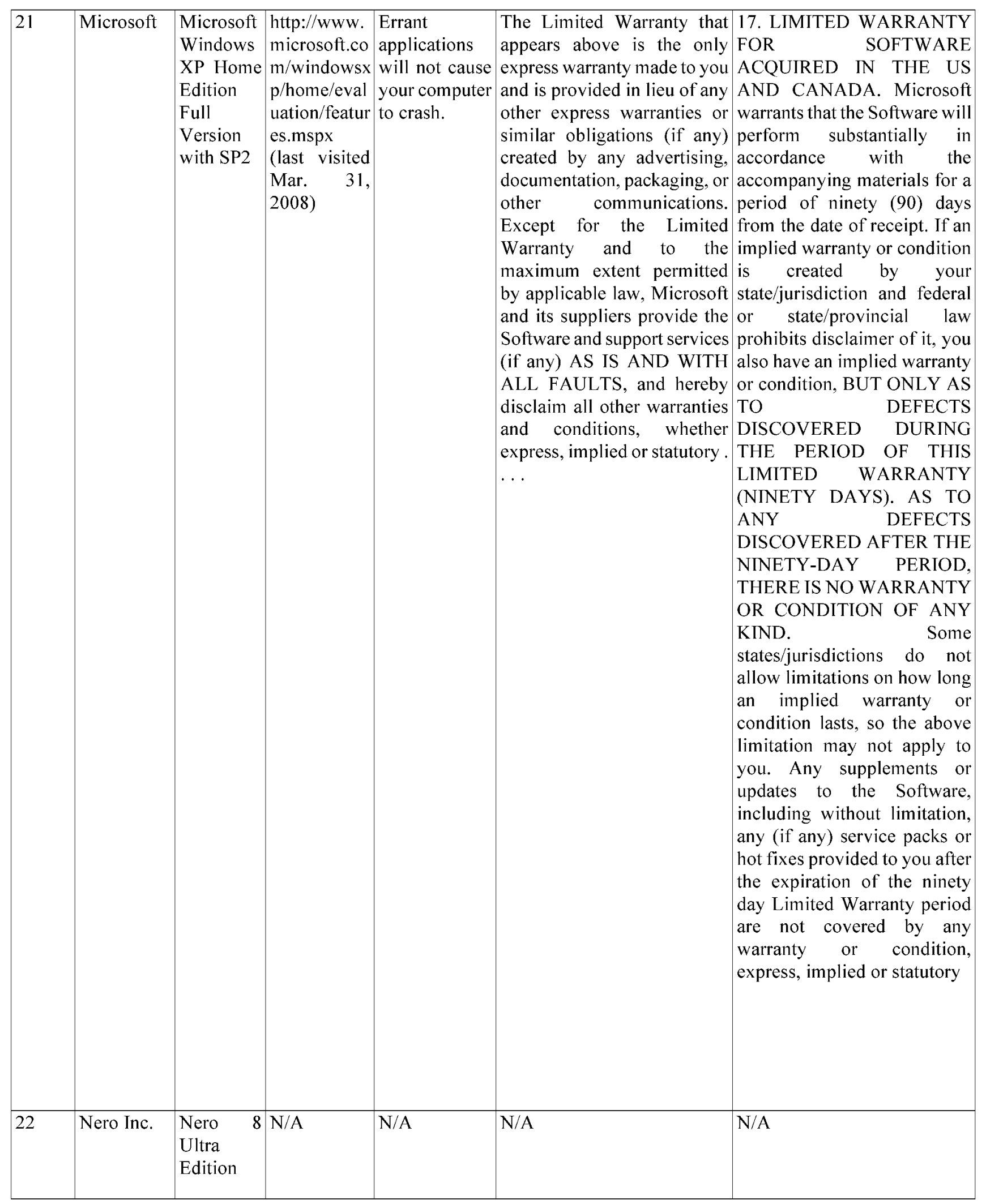




\begin{tabular}{|c|c|c|c|c|c|c|}
\hline 23 & Microsoft & \begin{tabular}{|l|} 
Microsoft \\
Streets \\
and Trips \\
2008
\end{tabular} & $\begin{array}{l}\text { http://www. } \\
\text { microsoft.co } \\
\text { m/streets/Pro } \\
\text { ductDetails.a } \\
\text { spx?pid=002 } \\
\text { \&active_tab } \\
\text { =Features } \\
\text { (last visited } \\
\text { Mar. 31, } \\
\text { 2008) }\end{array}$ & $\begin{array}{l}\text { Find Nearby } \\
\text { Places lets you } \\
\text { find more than } \\
1.6 \text { million } \\
\text { locations such } \\
\text { as parks, } \\
\text { ATMs, hotels, } \\
\text { landmarks, } \\
\text { and more } \\
\text { within up to } \\
50 \text { miles of } \\
\text { your current } \\
\text { position or } \\
\text { anywhere on } \\
\text { your route - } \\
\text { without being } \\
\text { connected to } \\
\text { the Web. }\end{array}$ & 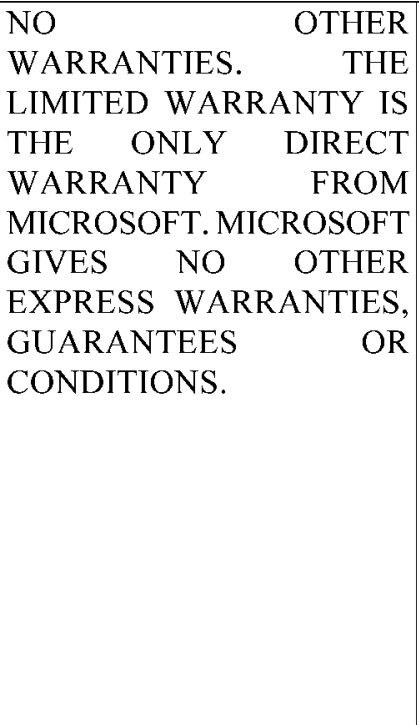 & $\begin{array}{l}\text { LIMITED WARRANTY. If } \\
\text { you follow the instructions, } \\
\text { the software will perform } \\
\text { substantially as described in } \\
\text { the Microsoft materials that } \\
\text { you receive in or with the } \\
\text { software. }\end{array}$ \\
\hline
\end{tabular}




\begin{tabular}{|c|c|c|c|c|c|c|}
\hline 24 & Corel & \begin{tabular}{|l|} 
Paint \\
Shop Pro \\
Photo X2
\end{tabular} & $\begin{array}{l}\text { http://www.c } \\
\text { orel.com/ser } \\
\text { vlet/Satellite } \\
\text { /us/en/Produ } \\
\text { ct/11852930 } \\
61925 \# \text { versi } \\
\text { onTabview= } \\
\text { tab0\&tabvie } \\
\text { w=tab2 }\end{array}$ & $\begin{array}{l}\text { View photos } \\
\text { and video } \\
\text { clips in more } \\
\text { than } 50 \text { file } \\
\text { formats. }\end{array}$ & 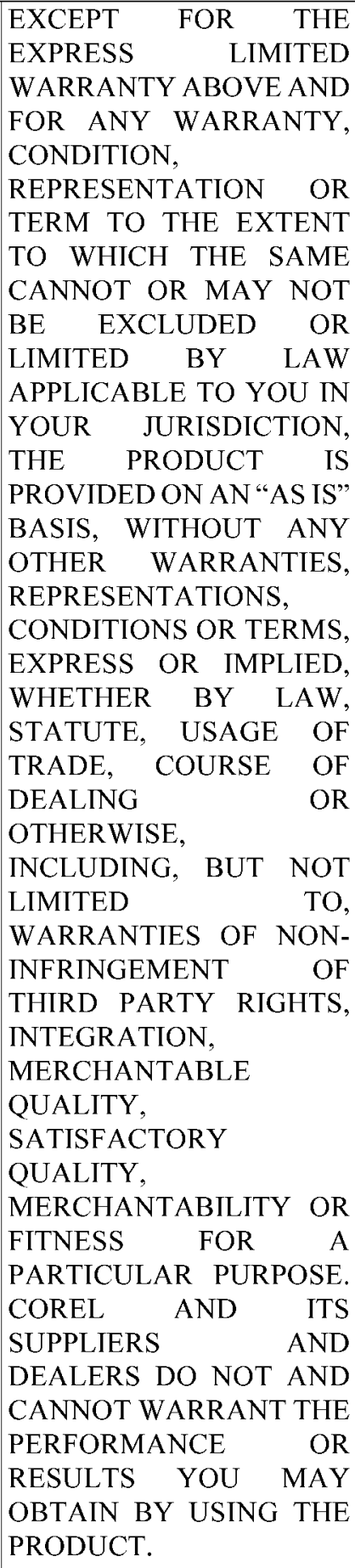 & 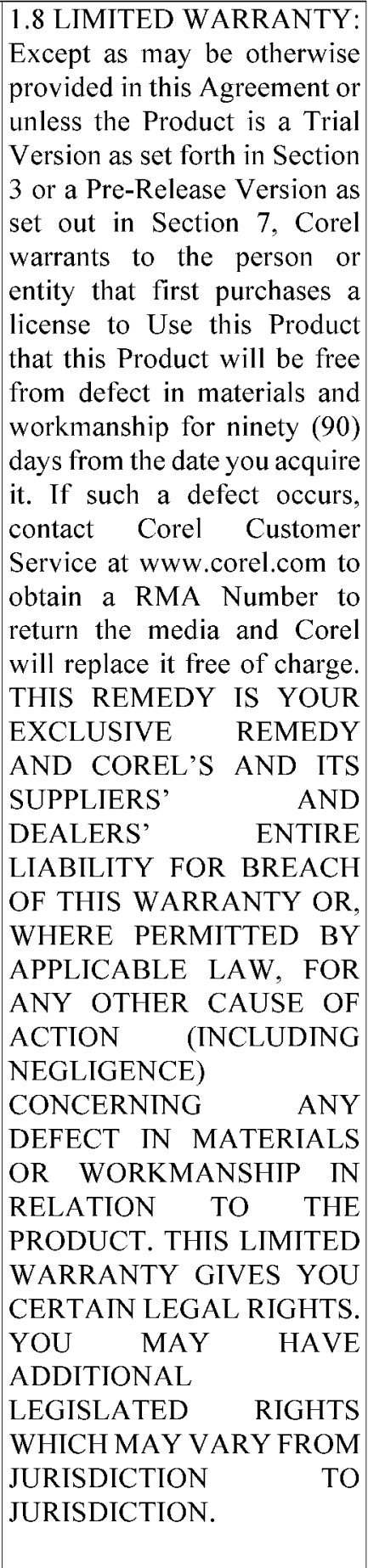 \\
\hline
\end{tabular}




\begin{tabular}{|c|c|c|c|c|c|c|}
\hline 30 & Microsoft & \begin{tabular}{|l|} 
Microsoft \\
Office \\
Profession \\
al 2007 \\
Full \\
Version
\end{tabular} & $\begin{array}{l}\text { http://office. } \\
\text { microsoft.co } \\
\text { m/en- } \\
\text { us/suites/FX } \\
1017594910 \\
33 . a s p x\end{array}$ & $\begin{array}{l}\text { Attachment } \\
\text { preview. View } \\
\text { attachments to } \\
\text { e-mail } \\
\text { messages } \\
\text { without } \\
\text { opening them } \\
\text { in Office } \\
\text { Outlook 2007. }\end{array}$ & 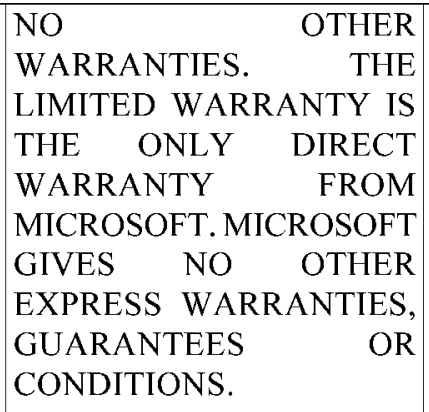 & $\begin{array}{l}\text { LIMITED WARRANTY. If } \\
\text { you follow the instructions, } \\
\text { the software will perform } \\
\text { substantially as described in } \\
\text { the Microsoft materials that } \\
\text { you receive in or with the } \\
\text { software. }\end{array}$ \\
\hline 31 & Microsoft & \begin{tabular}{|l|} 
Microsoft \\
Office \\
Standard \\
2007 Full \\
Version
\end{tabular} & $\begin{array}{l}\text { http://office. } \\
\text { microsoft.co } \\
\text { m/en- } \\
\text { us/suites/HA } \\
1016552210 \\
33 . a s p x\end{array}$ & $\begin{array}{l}\text { New support } \\
\text { for Portable } \\
\text { Document } \\
\text { Format (PDF) } \\
\text { and XML } \\
\text { Paper } \\
\text { Specification } \\
\text { (XPS) file } \\
\text { formats helps } \\
\text { ensure broader } \\
\text { distribution of } \\
\text { your } \\
\text { documents } \\
\text { with others.1 } \\
\text { Convert your } \\
\text { files to PDF or } \\
\text { XPS for } \\
\text { sharing with } \\
\text { users on any } \\
\text { platform. }\end{array}$ & $\begin{array}{|lr|}\text { NO } & \text { OTHER } \\
\text { WARRANTIES. } & \text { THE } \\
\text { LIMITED WARRANTY IS } \\
\text { THE ONLY } & \text { DIRECT } \\
\text { WARRANTY } & \text { FROM } \\
\text { MICROSOFT. MICROSOFT } \\
\text { GIVES NO } & \text { OTHER } \\
\text { EXPRESS } & \text { WARRANTIES, } \\
\text { EUARANTEES } & \text { OR } \\
\text { GUNDITIONS. } & \end{array}$ & $\begin{array}{l}\text { LIMITED WARRANTY. If } \\
\text { you follow the instructions, } \\
\text { the software will perform } \\
\text { substantially as described in } \\
\text { the Microsoft materials that } \\
\text { you receive in or with the } \\
\text { software. }\end{array}$ \\
\hline
\end{tabular}




\begin{tabular}{|c|c|c|c|c|c|c|}
\hline 32 & Microsoft & \begin{tabular}{|l|} 
Microsoft \\
Windows \\
XP \\
Profession \\
al Full \\
Version \\
with SP2
\end{tabular} & $\begin{array}{l}\text { http://www. } \\
\text { microsoft.co } \\
\mathrm{m} / \text { windowsx } \\
\mathrm{p} / \text { /evaluation/ } \\
\text { features/rem } \\
\text { oteaccess.ms } \\
\text { px } \\
\text { (last } \\
\text { Mar. } \\
2008 \text { ) }\end{array}$ & 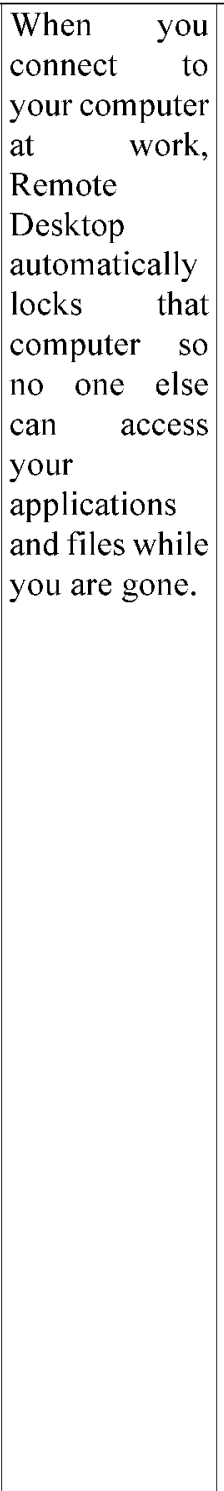 & $\begin{array}{l}\text { The Limited Warranty that } \\
\text { appears above is the only } \\
\text { express warranty made to you } \\
\text { and is provided in lieu of any } \\
\text { other express warranties or } \\
\text { similar obligations (if any) } \\
\text { created by any advertising, } \\
\text { documentation, packaging, or } \\
\text { other communications. } \\
\text { Except for the Limited } \\
\text { Warranty and to the } \\
\text { maximum extent permitted } \\
\text { by applicable law, Microsoft } \\
\text { and its suppliers provide the } \\
\text { Software and support services } \\
\text { (if any) AS IS AND WITH } \\
\text { ALL FAULTS, and hereby } \\
\text { disclaim all other warranties } \\
\text { and conditions, whether } \\
\text { express, implied or statutory. } \\
\ldots\end{array}$ & $\begin{array}{l}\text { 17. LIMITED WARRANTY } \\
\text { FOR SOFTWARE } \\
\text { ACQUIRED IN THE US } \\
\text { AND CANADA. Microsoft } \\
\text { warrants that the Software will } \\
\text { perform substantially in } \\
\text { accordance with the } \\
\text { accompanying materials for a } \\
\text { period of ninety (90) days } \\
\text { from the date of receipt. If an } \\
\text { implied warranty or condition } \\
\text { is created by your } \\
\text { state/jurisdiction and federal } \\
\text { or state/provincial law } \\
\text { prohibits disclaimer of it, you } \\
\text { also have an implied warranty } \\
\text { or condition, BUT ONLY AS } \\
\text { TO DEFECTS } \\
\text { DISCOVERED DURING } \\
\text { THE PERIOD OF THIS } \\
\text { LIMITED WARRANTY } \\
\text { (NINETY DAYS). AS TO } \\
\text { ANY DEFECTS } \\
\text { DISCOVERED AFTER THE } \\
\text { NINETY-DAY PERIOD, } \\
\text { THERE IS NO WARRANTY } \\
\text { OR CONDITION OF ANY } \\
\text { KIND. . Any supplements } \\
\text { or updates to the Software, } \\
\text { including without limitation, } \\
\text { any (if any) service packs or } \\
\text { hot fixes provided to you after } \\
\text { the expiration of the ninety } \\
\text { day Limited Warranty period } \\
\text { are not covered by any } \\
\text { warranty or condition, } \\
\text { express, implied or statutory. }\end{array}$ \\
\hline
\end{tabular}




\begin{tabular}{|c|c|c|c|c|c|c|}
\hline 33 & Intuit & \begin{tabular}{|l|}
\multicolumn{2}{|l|}{ Quickboo } \\
ks Pro \\
2007 \\
Small \\
Business \\
Financial \\
Software
\end{tabular} & $\begin{array}{l}\text { http://intuits } \\
\text { earch.intuit.c } \\
\text { om/search?e } \\
\text { ntqr=0\&Sear } \\
\text { ch.x=0\&sort } \\
=\text { date\%3AD } \\
\text { \%3AL\%3Ad } \\
\text { 1\&output=x } \\
\text { ml_no_dtd\& } \\
\text { ie=UTF- } \\
\text { 8\&shopperI } \\
\text { D=13324022 } \\
\text { 73\&opc=027 } \\
3400000 \& \text { cli } \\
\text { ent=quickbo } \\
\text { oks_site\&np } \\
\text { c=20559136 } \\
57 \& n u m=10 \\
\& \text { Search.y= } \\
0 \& \text { ud=1\&sit } \\
\text { e=quickbook } \\
\text { s_site\&oe=U } \\
\text { TF- } \\
\text { 8\&proxystyl } \\
\text { esheet=quick } \\
\text { books_site\& } \\
\text { q=quickbook } \\
\text { s+pro+2007 } \\
\text { +small+busi } \\
\text { ness\&btnG.x } \\
=0 \& \text { btnG.y= } \\
0 \\
\text { (last visited } \\
\text { Mar. } 31, \\
2008 \text { ) }\end{array}$ & $\begin{array}{l}\text { Create } 100+ \\
\text { customizable } \\
\text { reports, like } \\
\text { Profit \& Loss } \\
\text { Statements } \\
\text { and sales } \\
\text { reports, in two } \\
\text { clicks. } \\
\end{array}$ & 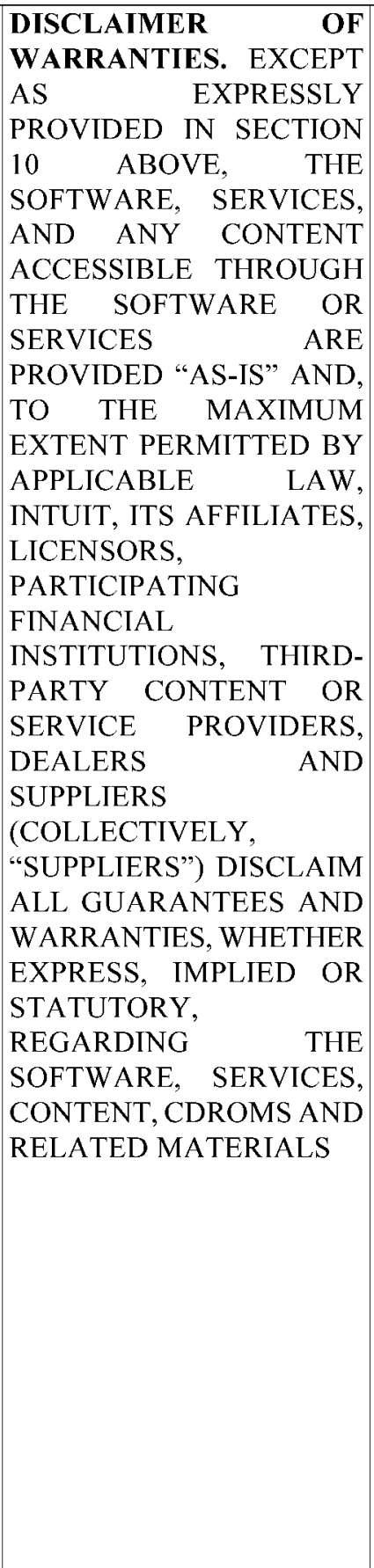 & $\begin{array}{l}\text { 10. SATISFACTION } \\
\text { GUARANTEED/LIMITED } \\
\text { WARRANTY. (i) } \\
\text { Satisfaction Guarantee. If you } \\
\text { are not satisfied with the } \\
\text { Software and (a) You } \\
\text { purchased the Software from a } \\
\text { retail store, you may uninstall } \\
\text { and delete all copies of the } \\
\text { Software from your } \\
\text { computer(s) and return it } \\
\text { within } 60 \text { days of purchase to } \\
\text { the store where you purchased } \\
\text { your license with a dated } \\
\text { receipt for a full refund. If the } \\
\text { store is unable or unwilling to } \\
\text { issue a refund or you obtained } \\
\text { the Software directly from } \\
\text { Intuit, you may uninstall and } \\
\text { delete all copies of the } \\
\text { Software and return the } \\
\text { Software with a dated receipt } \\
\text { or packing slip within } 60 \text { days } \\
\text { of purchase via U.S. mail to } \\
\text { Intuit Inc., Returns } \\
\text { Department, PO Box 190004, } \\
\text { Greenville, SC 29390-9004 or } \\
\text { via UPS to Intuit Inc., Returns } \\
\text { Department, 110 Hidden Lake } \\
\text { Circle, Duncan, SC 29334. } \\
\text {..(ii) Limited Warranty. (a) If } \\
\text { the CDROM on which the } \\
\text { Software is stored is defective, } \\
\text { then return the CDROM to } \\
\text { Intuit Inc., Returns } \\
\text { Department, PO Box 19004, } \\
\text { Greenville, SC 29390-9004 } \\
\text { within } 60 \text { days of shipment (or } \\
\text { in the case of a retail purchase, } \\
\text { within 60 days of purchase) } \\
\text { with a dated receipt or packing } \\
\text { slip, and a replacement } \\
\text { CDROM will be mailed to } \\
\text { you... }\end{array}$ \\
\hline
\end{tabular}




\begin{tabular}{|c|c|c|c|c|c|c|}
\hline 34 & Intuit & $\begin{array}{l}\text { Learning } \\
\text { Quickboo } \\
\text { ks } 2008\end{array}$ & $\begin{array}{l}\text { http://quickb } \\
\text { ooks.intuit.c } \\
\text { om/product/t } \\
\text { raining/learn } \\
\text { ing_quickbo } \\
\text { oks.jhtml?vi } \\
\text { ew=overvie } \\
\text { w\#tabAncho } \\
\text { r }\end{array}$ & $\begin{array}{l}\text { Duration: } \\
\text { total hours of } \\
\text { training. }\end{array}$ & 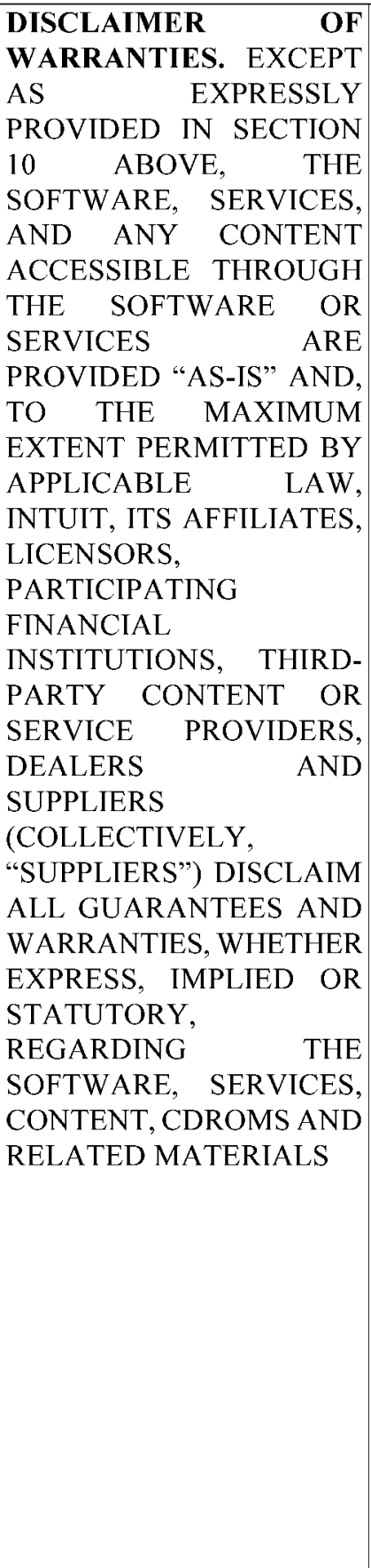 & $\begin{array}{l}\text { 10. SATISFACTION } \\
\text { GUARANTEED/LIMITED } \\
\text { WARRANTY. (i) } \\
\text { Satisfaction Guarantee. If you } \\
\text { are not satisfied with the } \\
\text { Software and (a) You } \\
\text { purchased the Software from a } \\
\text { retail store, you may uninstall } \\
\text { and delete all copies of the } \\
\text { Software from your } \\
\text { computer(s) and return it } \\
\text { within } 60 \text { days of purchase to } \\
\text { the store where you purchased } \\
\text { your license with a dated } \\
\text { receipt for a full refund. If the } \\
\text { store is unable or unwilling to } \\
\text { issue a refund or you obtained } \\
\text { the Software directly from } \\
\text { Intuit, you may uninstall and } \\
\text { delete all copies of the } \\
\text { Software and return the } \\
\text { Software with a dated receipt } \\
\text { or packing slip within } 60 \text { days } \\
\text { of purchase via U.S. mail to } \\
\text { Intuit Inc., Returns } \\
\text { Department, PO Box } 190004, \\
\text { Greenville, SC } 29390-9004 \text { or } \\
\text { via UPS to Intuit Inc., Returns } \\
\text { Department, } 110 \text { Hidden Lake } \\
\text { Circle, Duncan, SC 29334. } \\
\text {..(ii) Limited Warranty. (a) If } \\
\text { the CDROM on which the } \\
\text { Software is stored is defective, } \\
\text { then return the CDROM to } \\
\text { Intuit Inc., Returns } \\
\text { Department, PO Box } 19004, \\
\text { Greenville, SC 29390-9004 } \\
\text { within } 60 \text { days of shipment (or } \\
\text { in the case of a retail purchase, } \\
\text { within } 60 \text { days of purchase) } \\
\text { with a dated receipt or packing } \\
\text { slip, and a replacement } \\
\text { CDROM will be mailed to } \\
\text { you ... }\end{array}$ \\
\hline
\end{tabular}




\begin{tabular}{|c|c|c|c|c|c|c|}
\hline 35 & $\begin{array}{l}\text { Rosetta } \\
\text { Stone }\end{array}$ & $\begin{array}{l}\text { Rosetta } \\
\text { Stone V3 } \\
\text { Spanish } \\
\text { (Latin } \\
\text { America) } \\
\text { Level 1-2- } \\
\text { 3 Personal } \\
\text { Edition }\end{array}$ & $\begin{array}{l}\text { http://www.r } \\
\text { osettastone.c } \\
\text { om/personal/ } \\
\text { languages/sp } \\
\text { anish-latin- } \\
\text { america/leve } \\
\text { l-1-2-3 } \\
\text { (last visited } \\
\text { Mar. 31, } \\
\text { 2008) }\end{array}$ & $\begin{array}{l}\text { Level 1,2\&3 } \\
\text { Set Includes } \\
\text { The Basics } \\
\text { Nouns, verbs, } \\
\text { adjectives, } \\
\text { numbers, } \\
\text { questions, } \\
\text { colors, } \\
\text { clothing. } \\
\text { Friends and } \\
\text { Family Ages, } \\
\text { family } \\
\text { relations, } \\
\text { household } \\
\text { items, } \\
\text { introductions, } \\
\text { landmarks, } \\
\text { states, } \\
\text { descriptions. }\end{array}$ & 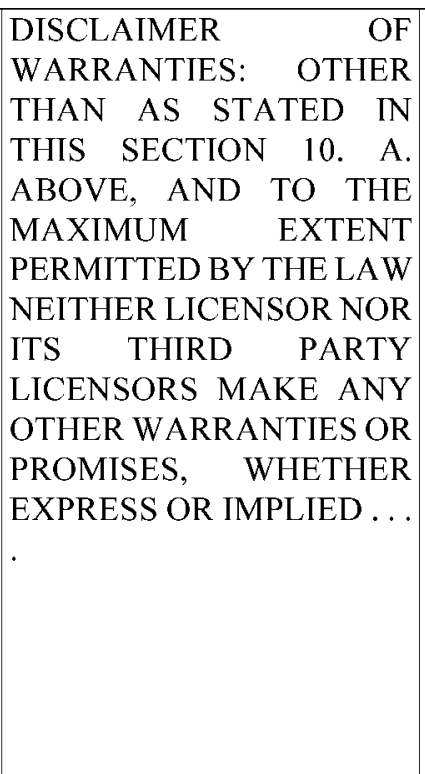 & $\begin{array}{l}\text { A. LIMITED WARRANTY } \\
\text { AND DISCLAIMER: } \\
\text { Licensor warrants that the } \\
\text { Software will perform } \\
\text { substantially in accordance } \\
\text { with the descriptions and } \\
\text { specifications in the } \\
\text { documentation accompanying } \\
\text { such Software for a period of } \\
\text { ninety (90) days after purchase } \\
\text { of the Software under normal } \\
\text { use. Notwithstanding anything } \\
\text { to the contrary, Licensor } \\
\text { makes no representation or } \\
\text { warranty with respect to any } \\
\text { third party software, and } \\
\text { undertakes no obligations with } \\
\text { respect to any third party } \\
\text { software. }\end{array}$ \\
\hline 36 & Symantec & \begin{tabular}{|l|} 
Norton \\
Antivirus \\
$2008 \quad 1$ \\
User
\end{tabular} & $\begin{array}{l}\text { http://www.s } \\
\text { ymantec.co } \\
\text { m/norton/pro } \\
\text { ducts/overvi } \\
\text { ew.jsp?pcid } \\
\text { =is\&pvid=n } \\
\text { av2008 } \\
\text { (last visited } \\
\text { Mar. 31, } \\
\text { 2008) }\end{array}$ & \begin{tabular}{|lr} 
One & click \\
access & to \\
expert & \\
support. & \\
\end{tabular} & $\begin{array}{|lr|}\text { TO THE MAXIMUM } \\
\text { EXTENT PERMITTED BY } \\
\text { APPLICABLE LAW, THE } \\
\text { ABOVE } \\
\text { EXARRANTY IS } \\
\text { EX } & \text { ALL } \\
\text { OF } & \text { OTHER } \\
\text { WARRANTIES, WHETHER } \\
\text { EXPRESS OR IMPLIED ... }\end{array}$ & $\begin{array}{l}\text { 6. Limited Warranty: } \\
\text { Symantec warrants that the } \\
\text { media on which the Software } \\
\text { is distributed will be free from } \\
\text { defects for a period of sixty } \\
\text { (60) days from the date of } \\
\text { delivery of the Software to } \\
\text { You. Your sole remedy in the } \\
\text { event of a breach of this } \\
\text { warranty will be that } \\
\text { Symantec will, at its option, } \\
\text { replace any defective media } \\
\text { returned to Symantec within } \\
\text { the warranty period or refund } \\
\text { the money You paid for the } \\
\text { Software. Symantec does not } \\
\text { warrant that the Software will } \\
\text { meet Your requirements or } \\
\text { that operation of the Software } \\
\text { will be uninterrupted or that } \\
\text { the Software will be error- } \\
\text { free. }\end{array}$ \\
\hline
\end{tabular}




\begin{tabular}{|c|c|c|c|c|c|c|}
\hline 38 & Adobe & \begin{tabular}{|l} 
Adobe \\
Acrobat \\
Standard \\
8.0
\end{tabular} & $\begin{array}{l}\text { http://www.a } \\
\text { dobe.com/pr } \\
\text { oducts/acrob } \\
\text { atpro/acrobat } \\
\text { std.html } \\
\text { (last visited } \\
\text { Mar. } 31 \text {, } \\
\text { 2008) }\end{array}$ & $\begin{array}{l}\text { Save Adobe } \\
\text { PDF files as } \\
\text { Microsoft } \\
\text { Word } \\
\text { documents, } \\
\text { retaining the } \\
\text { layout, fonts, } \\
\text { formatting, } \\
\text { and tables, to } \\
\text { facilitate reuse } \\
\text { of content. }\end{array}$ & $\begin{array}{l}\text {... the Software and access } \\
\text { to any websites, online } \\
\text { services and CD Services as- } \\
\text { is and with all faults and } \\
\text { expressly disclaim all other } \\
\text { warranties, conditions, } \\
\text { representations or terms, } \\
\text { express or implied, whether } \\
\text { by statute, common law, } \\
\text { custom, usage or otherwise.. }\end{array}$ & $\begin{array}{l}\text { 6. LIMITED WARRANTY. } \\
\text { Except as may be otherwise } \\
\text { provided in Section 14, Adobe } \\
\text { warrants to the individual or } \\
\text { entity that first purchases a } \\
\text { license for the Software for } \\
\text { use pursuant to the terms of } \\
\text { this agreement that the } \\
\text { Software will perform } \\
\text { substantially in accordance } \\
\text { with the Documentation for } \\
\text { the ninety (90) day period } \\
\text { following receipt of the } \\
\text { Software when used on the } \\
\text { recommended operating } \\
\text { system and hardware } \\
\text { configuration. Non-substantial } \\
\text { variation of performance from } \\
\text { the Documentation does not } \\
\text { establish a warranty right. }\end{array}$ \\
\hline 40 & Adobe & \begin{tabular}{|l|} 
Adobe \\
Photoshop \\
CS3 \\
Upgrade
\end{tabular} & $\begin{array}{l}\text { http://www.a } \\
\text { dobe.com/pr } \\
\text { oducts/photo } \\
\text { shop/photos } \\
\text { hop/upgrade/ } \\
\text { (last visited } \\
\text { Mar. 31, } \\
2008 \text { ) }\end{array}$ & 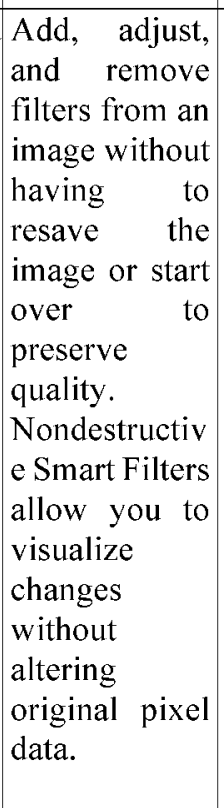 & $\begin{array}{l}\ldots \text { the Software and access } \\
\text { to any websites, online } \\
\text { services and CD Services as- } \\
\text { is and with all faults and } \\
\text { expressly disclaim all other } \\
\text { warranties, conditions, } \\
\text { representations or terms, } \\
\text { express or implied, whether } \\
\text { by statute, common law, } \\
\text { custom, usage or otherwise.. }\end{array}$ & $\begin{array}{l}\text { 6. LIMITED WARRANTY. } \\
\text { Except as may be otherwise } \\
\text { provided in Section } 14 \text {, Adobe } \\
\text { warrants to the individual or } \\
\text { entity that first purchases a } \\
\text { license for the Software for } \\
\text { use pursuant to the terms of } \\
\text { this agreement that the } \\
\text { Software will perform } \\
\text { substantially in accordance } \\
\text { with the Documentation for } \\
\text { the ninety (90) day period } \\
\text { following receipt of the } \\
\text { Software when used on the } \\
\text { recommended operating } \\
\text { system and hardware } \\
\text { configuration. Non-substantial } \\
\text { variation of performance from } \\
\text { the Documentation does not } \\
\text { establish a warranty right. }\end{array}$ \\
\hline
\end{tabular}




\begin{tabular}{|c|c|c|c|c|c|c|}
\hline 41 & Adobe & \begin{tabular}{|l|} 
Adobe \\
Photoshop \\
Elements \\
4.0 (Mac)
\end{tabular} & $\begin{array}{l}\text { No Longer } \\
\text { available on } \\
\text { Adobe.com }\end{array}$ & $\begin{array}{l}\text { No Longer } \\
\text { available on } \\
\text { Adobe.com }\end{array}$ & $\begin{array}{l}\text {... the Software and access } \\
\text { to any websites, online } \\
\text { services and CD Services as- } \\
\text { is and with all faults and } \\
\text { expressly disclaim all other } \\
\text { warranties, conditions, } \\
\text { representations or terms, } \\
\text { express or implied, whether } \\
\text { by statute, common law, } \\
\text { custom, usage or otherwise.. } \\
\text {. }\end{array}$ & $\begin{array}{l}\text { 6. LIMITED WARRANTY. } \\
\text { Except as may be otherwise } \\
\text { provided in Section 14, Adobe } \\
\text { warrants to the individual or } \\
\text { entity that first purchases a } \\
\text { license for the Software for } \\
\text { use pursuant to the terms of } \\
\text { this agreement that the } \\
\text { Software will perform } \\
\text { substantially in accordance } \\
\text { with the Documentation for } \\
\text { the ninety (90) day period } \\
\text { following receipt of the } \\
\text { Software when used on the } \\
\text { recommended operating } \\
\text { system and hardware } \\
\text { configuration. Non-substantial } \\
\text { variation of performance from } \\
\text { the Documentation does not } \\
\text { establish a warranty right. }\end{array}$ \\
\hline
\end{tabular}




\begin{tabular}{|c|c|c|c|c|c|c|}
\hline 44 & Intuit & \begin{tabular}{|l|} 
Quicken \\
2008 \\
Premier
\end{tabular} & $\begin{array}{l}\text { http://quicke } \\
\text { n.intuit.com/ } \\
\text { personal- } \\
\text { finance/prem } \\
\text { ier-portfolio- } \\
\text { management } \\
\text {.jhtml?lid=si } \\
\text { te_banner } \\
\text { (last visited } \\
\text { Mar. 31, } \\
\text { 2008) }\end{array}$ & 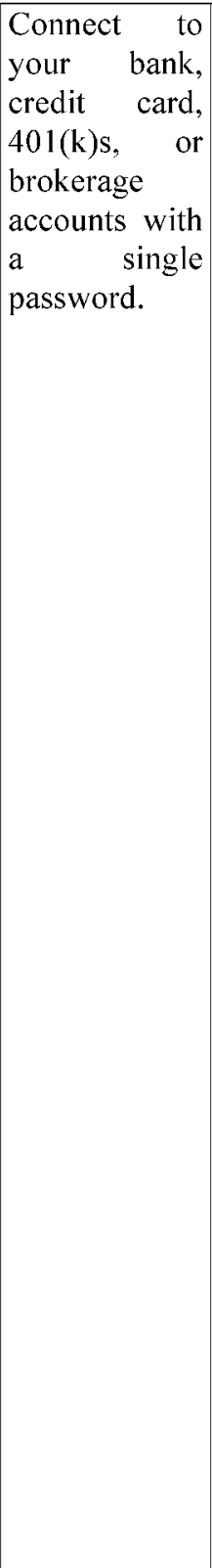 & 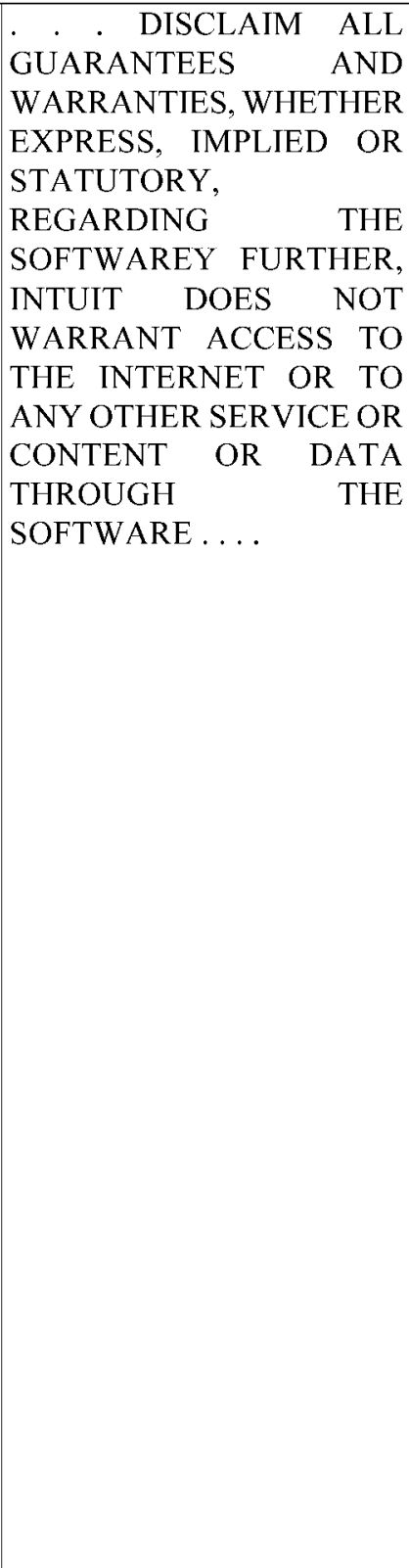 & $\begin{array}{l}\text { 9. SATISFACTION } \\
\text { GUARANTEED. If you are } \\
\text { not satisfied with the Software } \\
\text { and (a) You purchased the } \\
\text { Software from a retail store, } \\
\text { you may uninstall and delete } \\
\text { all copies of the Software } \\
\text { from your computer(s) and } \\
\text { return it within } 60 \text { days of } \\
\text { purchase to the store where } \\
\text { you purchased your license } \\
\text { with a dated receipt for a full } \\
\text { refund. If the store is unable or } \\
\text { unwilling to issue a refund or } \\
\text { you obtained the Software } \\
\text { directly from Intuit, you may } \\
\text { uninstall and delete all copies } \\
\text { of the Software and return the } \\
\text { Software with a dated receipt } \\
\text { or packing slip within } 60 \text { days } \\
\text { of purchase via U.S. mail to } \\
\text { Intuit Inc...(b) You obtained } \\
\text { the Software directly from } \\
\text { Intuit via an Internet } \\
\text { download, you may submit a } \\
\text { written request to Intuit } \\
\text { including your name, contact } \\
\text { and product order information } \\
\text { to Intuit Inc. . . (c) The } \\
\text { Software was pre-installed on } \\
\text { your computer when you } \\
\text { bought it, or if CDROMs } \\
\text { came packaged with your } \\
\text { computer at no extra charge, } \\
\text { follow the manufacturer's } \\
\text { applicable return policy; or (d) } \\
\text { You obtained the Software by } \\
\text { downloading it on your } \\
\text { computer, contact the [site } \\
\text { provider]. }\end{array}$ \\
\hline
\end{tabular}




\begin{tabular}{|c|c|c|c|c|c|c|}
\hline 47 & \begin{tabular}{|l|} 
Pinnacle \\
Systems
\end{tabular} & $\begin{array}{l}\text { Pinnacle } \\
\text { Studio } \\
\text { Ultimate } \\
\text { Version } \\
11\end{array}$ & $\begin{array}{l}\text { http://www. } \\
\text { pinnaclesys. } \\
\text { com/PublicS } \\
\text { ite/us/Produc } \\
\text { ts/Consumer } \\
+ \text { +Products/H } \\
\text { ome+Video/ } \\
\text { Studio+Fami } \\
\text { ly/Studio+Ul } \\
\text { timate+11 }\end{array}$ & $\begin{array}{|lr|}\text { Pinnacle } & \\
\text { Studio } & \text { Plus } \\
\text { edits } & \text { native } \\
\text { HDV r or } & \\
\text { AVCHD } & \\
\text { footage and } \\
\text { then authors } \\
\text { HD r DVD } \\
\text { format discs } \\
\text { that will play } \\
\text { on the latest } \\
\text { HD players. }\end{array}$ & 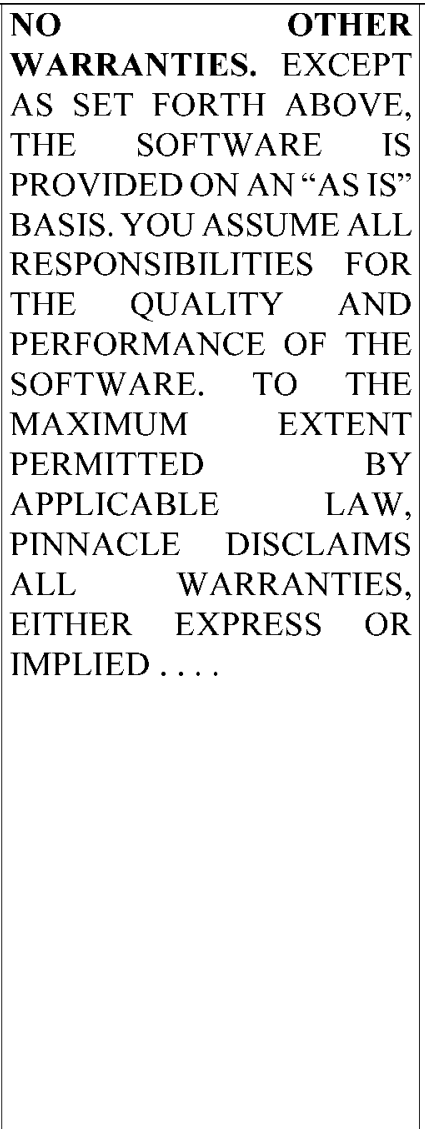 & $\begin{array}{l}\text { 9. Limited Warranty. } \\
\text { Pinnacle warrants to the } \\
\text { original licensee that the } \\
\text { Software, as delivered, will } \\
\text { perform in accordance with } \\
\text { the accompanying } \\
\text { documentation for a period of } \\
30 \text { days from the date of the } \\
\text { original purchase ("Limited } \\
\text { Warranty"). Pinnacle's entire } \\
\text { liability and your exclusive } \\
\text { remedy for breach of the } \\
\text { preceding Limited Warranty } \\
\text { shall be, at Pinnacle's sole } \\
\text { option, repair or replacement } \\
\text { of the Software that does not } \\
\text { meet the warranty set forth } \\
\text { herein and that is returned to } \\
\text { Pinnacle. This limited } \\
\text { warranty shall be void if } \\
\text { failure of the Software has } \\
\text { resulted from any accident, } \\
\text { abuse, misuse or } \\
\text { misapplication by you. Any } \\
\text { replacement Software will be } \\
\text { warranted for the remainder of } \\
\text { the original warranty period or } \\
30 \text { days, whichever is longer. }\end{array}$ \\
\hline 48 & $\begin{array}{l}\text { Rosetta } \\
\text { Stone }\end{array}$ & \begin{tabular}{|l|} 
Rosetta \\
Stone V3 \\
Spanish \\
(Latin \\
America) \\
Level 1 1 \\
Personal \\
Edition
\end{tabular} & $\begin{array}{l}\text { http://Www.r } \\
\text { osettastone.c } \\
\text { om/personal/ } \\
\text { languages/sp } \\
\text { anish-latin- } \\
\text { america/leve } \\
\text { l-1 } \\
\text { (last visited } \\
\text { Mar. } \quad 31 \text {, } \\
2008)\end{array}$ & $\begin{array}{l}\text { Level } \\
\text { Includes } 4 \\
\text { Major Units } \\
\text { Covering: } \\
\text { Work and } \\
\text { School - } \\
\text { Times of day, } \\
\text { greetings, } \\
\text { calendar } \\
\text { terms, body } \\
\text { parts, } \\
\text { speaking, } \\
\text { personal } \\
\text { hygiene. }\end{array}$ & 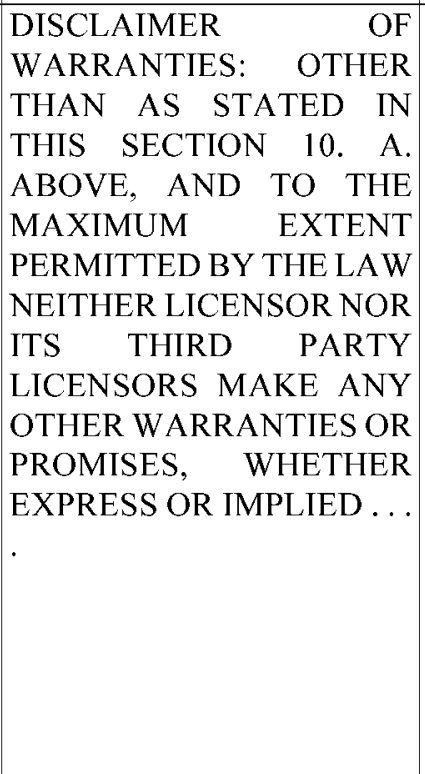 & $\begin{array}{l}\text { A. LIMITED WARRANTY } \\
\text { AND DISCLAIMER: } \\
\text { Licensor warrants that the } \\
\text { Software will perform } \\
\text { substantially in accordance } \\
\text { with the descriptions and } \\
\text { specifications in the } \\
\text { documentation accompanying } \\
\text { such Software for a period of } \\
\text { ninety (90) days after purchase } \\
\text { of the Software under normal } \\
\text { use. Notwithstanding anything } \\
\text { to the contrary, Licensor } \\
\text { makes no representation or } \\
\text { warranty with respect to any } \\
\text { third party software, and } \\
\text { undertakes no obligations with } \\
\text { respect to any third party } \\
\text { software. }\end{array}$ \\
\hline
\end{tabular}




\section{Warranties and Disclaimers in the Electronic Age}

\begin{tabular}{|c|c|c|c|c|c|c|}
\hline 50 & $\begin{array}{l}\text { Kaspersky } \\
\text { Lab }\end{array}$ & $\begin{array}{l}\text { Kaspersky } \\
\text { Internet } \\
\text { Security } \\
7.0 \\
\text { User }\end{array}$ & $\begin{array}{l}\text { http://usa.ka } \\
\text { spersky.com } \\
\text { /products_se } \\
\text { rvices/intern } \\
\text { et- } \\
\text { security.php } \\
\text { (last visited } \\
\text { Mar. 31, } \\
2008)\end{array}$ & $\begin{array}{l}\text { Parental } \\
\text { controls limit } \\
\text { online time } \\
\text { and access to } \\
\text { forbidden sites } \\
\text { (with } \\
\text { tracking). }\end{array}$ & $\begin{array}{l}\text { The warranties and } \\
\text { conditions stated in this } \\
\text { Agreement are in lieu of all } \\
\text { other conditions, warranties } \\
\text { or other terms concerning the } \\
\text { supply or purported supply } \\
\text { of, failure to supply or delay } \\
\text { in supplying the Software or } \\
\text { the Documentation which } \\
\text { might but for this paragraph } \\
\text { (vi) have effect between the } \\
\text { Kaspersky Lab and your or } \\
\text { would otherwise be implied } \\
\text { into or incorporated into this } \\
\text { Agreement or any collateral } \\
\text { contract, whether by statute, } \\
\text { common law or otherwise, all } \\
\text { of which are hereby excluded } \\
\text { (including, without } \\
\text { limitation, the implied } \\
\text { conditions, warranties or } \\
\text { other terms as to satisfactory } \\
\text { quality, fitness for purpose or } \\
\text { as to the use of reasonable } \\
\text { skill and care). }\end{array}$ & $\begin{array}{l}\text { 5. Limited Warranty. (i) } \\
\text { Kaspersky Lab warrants that } \\
\text { for six (6) months from first } \\
\text { download or installation the } \\
\text { Software purchased on a } \\
\text { physical medium will perform } \\
\text { substantially in accordance } \\
\text { with the functionality } \\
\text { described in the } \\
\text { Documentation when operated } \\
\text { properly and in the manner } \\
\text { specified in the } \\
\text { Documentation. }\end{array}$ \\
\hline
\end{tabular}




\begin{tabular}{|c|c|c|c|c|c|c|}
\hline 52 & Microsoft & $\begin{array}{l}\text { Microsoft } \\
\text { Windows } \\
\text { XP Home } \\
\text { Edition } \\
\text { SP2B for } \\
\text { System } \\
\text { Builders }\end{array}$ & $\begin{array}{l}\text { http://www. } \\
\text { microsoft.co } \\
\mathrm{m} / \text { windowsx } \\
\text { p/home/eval } \\
\text { uation/featur } \\
\text { es.mspx } \\
\text { (last visited } \\
\text { Mar. 31, } \\
2008)\end{array}$ & \begin{tabular}{|l|} 
Errant \\
applications \\
will not cause \\
your computer \\
to crash. \\
\end{tabular} & $\begin{array}{l}\text { The Limited Warranty that } \\
\text { appears above is the only } \\
\text { express warranty made to you } \\
\text { and is provided in lieu of any } \\
\text { other express warranties or } \\
\text { similar obligations (if any) } \\
\text { created by any advertising, } \\
\text { documentation, packaging, or } \\
\text { other communications. } \\
\text { Except for the Limited } \\
\text { Warranty and to the } \\
\text { maximum extent permitted } \\
\text { by applicable law, Microsoft } \\
\text { and its suppliers provide the } \\
\text { Software and support services } \\
\text { (if any) AS IS AND WITH } \\
\text { ALL FAULTS, and hereby } \\
\text { disclaim all other warranties } \\
\text { and conditions, whether } \\
\text { express, implied or statutory. } \\
\text {. }\end{array}$ & $\begin{array}{l}\text { 17. LIMITED WARRANTY } \\
\text { FOR SOFTWARE } \\
\text { ACQUIRED IN THE US } \\
\text { AND CANADA. Microsoft } \\
\text { warrants that the Software will } \\
\text { perform substantially in } \\
\text { accordance with the } \\
\text { accompanying materials for a } \\
\text { period of ninety (90) days } \\
\text { from the date of receipt. If an } \\
\text { implied warranty or condition } \\
\text { is created by your } \\
\text { state/jurisdiction and federal } \\
\text { or state/provincial law } \\
\text { prohibits disclaimer of it, you } \\
\text { also have an implied warranty } \\
\text { or condition, BUT ONLY AS } \\
\text { TO DEFECTS } \\
\text { DISCOVERED DURING } \\
\text { THE PERIOD OF THIS } \\
\text { LIMITED WARRANTY } \\
\text { (NINETY DAYS). AS TO } \\
\text { ANY DEFECTS } \\
\text { DISCOVERED AFTER THE } \\
\text { NINETY-DAY PERIOD, } \\
\text { THERE IS NO WARRANTY } \\
\text { OR CONDITION OF ANY } \\
\text { KIND. Some } \\
\text { states/jurisdictions do not } \\
\text { allow limitations on how long } \\
\text { an implied warranty or } \\
\text { condition lasts, so the above } \\
\text { limitation may not apply to } \\
\text { you. Any supplements or } \\
\text { updates to the Software, } \\
\text { including without limitation, } \\
\text { any (if any) service packs or } \\
\text { hot fixes provided to you after } \\
\text { the expiration of the ninety } \\
\text { day Limited Warranty period } \\
\text { are not covered by any } \\
\text { warranty or condition, } \\
\text { express, implied or statutory. }\end{array}$ \\
\hline
\end{tabular}




\begin{tabular}{|c|c|c|c|c|c|c|}
\hline 53 & Adobe & \begin{tabular}{|l|} 
Adobe \\
Acrobat \\
8.0 \\
Profession \\
al \\
\end{tabular} & $\begin{array}{l}\text { http://Www.a } \\
\text { dobe.com/pr } \\
\text { oducts/acrob } \\
\text { atpro/ } \\
\text { (last visited } \\
\text { Mar. } 31 \text {, } \\
\text { 2008) }\end{array}$ & $\begin{array}{|lr|}\text { Combine } & \\
\text { multiple } & \text { files } \\
\text { into } & \text { a } \\
\text { searchable, } \\
\text { sortable PDF } \\
\text { package that } \\
\text { maintains the } \\
\text { individual } \\
\text { security r } \\
\text { settings and } \\
\text { digital } \\
\text { signatures of } \\
\text { each included } \\
\text { PDF } \\
\text { document. }\end{array}$ & $\begin{array}{l}\ldots \text { the Software and access } \\
\text { to any websites, online } \\
\text { services and CD Services as- } \\
\text { is and with all faults and } \\
\text { expressly disclaim all other } \\
\text { warranties, conditions, } \\
\text { representations or terms, } \\
\text { express or implied, whether } \\
\text { by statute, common law, } \\
\text { custom, usage or otherwise.. } \\
\text {. }\end{array}$ & $\begin{array}{l}\text { 6. LIMITED WARRANTY. } \\
\text { Except as may be otherwise } \\
\text { provided in Section } 14 \text {, Adobe } \\
\text { warrants to the individual or } \\
\text { entity that first purchases a } \\
\text { license for the Software for } \\
\text { use pursuant to the terms of } \\
\text { this agreement that the } \\
\text { Software will perform } \\
\text { substantially in accordance } \\
\text { with the Documentation for } \\
\text { the ninety (90) day period } \\
\text { following receipt of the } \\
\text { Software when used on the } \\
\text { recommended operating } \\
\text { system and hardware } \\
\text { configuration. Non-substantial } \\
\text { variation of performance from } \\
\text { the Documentation does not } \\
\text { establish a warranty right. }\end{array}$ \\
\hline 55 & Microsoft & \begin{tabular}{|l|} 
Microsoft \\
Publisher \\
2007
\end{tabular} & $\begin{array}{l}\text { http://office. } \\
\text { microsoft.co } \\
\text { m/en- } \\
\text { us/publisher// } \\
\text { HA1003856 } \\
\text { 91033.aspx }\end{array}$ & $\begin{array}{l}\text { In three } \\
\text { you steps, } \\
\text { you can } \\
\text { successfully } \\
\text { create mail } \\
\text { merges. }\end{array}$ & $\begin{array}{l}\text { The Limited Warranty that } \\
\text { appears above is the only } \\
\text { express warranty made to you } \\
\text { and is provided in lieu of any } \\
\text { other express warranties or } \\
\text { similar obligations (if any) } \\
\text { created by any advertising, } \\
\text { documentation, packaging, or } \\
\text { other communications. } \\
\text { Except for the Limited } \\
\text { Warranty and to the } \\
\text { maximum extent permitted } \\
\text { by applicable law, Microsoft } \\
\text { and its suppliers provide the } \\
\text { Software and support services } \\
\text { (if any) AS IS AND WITH } \\
\text { ALL FAULTS, and hereby } \\
\text { disclaim all other warranties } \\
\text { and conditions, whether } \\
\text { express, implied or statutory. }\end{array}$ & $\begin{array}{l}\text { 16. LIMITED WARRANTY } \\
\text { FOR SOFTWARE } \\
\text { ACQUIRED IN THE US } \\
\text { AND CANADA. Microsoft } \\
\text { warrants that the Software will } \\
\text { perform substantially in } \\
\text { accordance with the } \\
\text { accompanying materials for a } \\
\text { period of ninety }(90) \text { days } \\
\text { from the date of receipt. }\end{array}$ \\
\hline
\end{tabular}




\begin{tabular}{|c|c|c|c|c|c|c|}
\hline 56 & Microsoft & \begin{tabular}{|l|} 
Money \\
Plus \\
Deluxe
\end{tabular} & $\begin{array}{l}\text { http://www. } \\
\text { microsoft.co } \\
\mathrm{m} / \text { money/Pr } \\
\text { oductDetails } \\
\text { aspx?pid=0 } \\
03\end{array}$ & $\begin{array}{l}\text { Attach links to } \\
\text { important files } \\
\text { such as check } \\
\text { images or } \\
\text { scanned } \\
\text { receipts right } \\
\text { from } \\
\text { transactions in } \\
\text { the Money } \\
\text { account } \\
\text { register. }\end{array}$ & \begin{tabular}{lrr} 
NO & \multicolumn{2}{r}{ OTHER } \\
WARRANTIES. & TO THE \\
MAXIMUM & EXTENT \\
PERMITTED & BY \\
APPLICABLE & LAW, \\
MICROSOFT & AND ITS \\
SUPPLIERS & DISCLAIM \\
ALL & OTHER \\
WARRANTIES & AND \\
CONDITIONS, & EITHER \\
EXPRESS OR IMPLIED ...
\end{tabular} & $\begin{array}{l}\text { B. LIMITED WARRANTY } \\
\text { FOR SOFTWARE } \\
\text { ACQUIRED IN THE U.S. } \\
\text { AND CANADA. Microsoft } \\
\text { warrants that (a) the software } \\
\text { will perform substantially in } \\
\text { accordance with the } \\
\text { accompanying written } \\
\text { materials for a period of } \\
\text { ninety (90) days from the date } \\
\text { of receipt, and (b) any support } \\
\text { services provided by } \\
\text { Microsoft shall be } \\
\text { substantially as described in } \\
\text { applicable written materials } \\
\text { provided to you by Microsoft, } \\
\text { and Microsoft support } \\
\text { engineers will make } \\
\text { commercially reasonable } \\
\text { efforts to solve any problem } \\
\text { issues. Some states and } \\
\text { jurisdictions do not allow } \\
\text { limitations on duration of an } \\
\text { implied warranty, so the above } \\
\text { limitation may not apply to } \\
\text { you. To the extent allowed by } \\
\text { applicable law, implied } \\
\text { warranties on the software, if } \\
\text { any, are limited to ninety ( } 90) \\
\text { days. }\end{array}$ \\
\hline
\end{tabular}




\begin{tabular}{|c|c|c|c|c|c|c|}
\hline 57 & Microsoft & \begin{tabular}{|l|} 
Microsoft \\
Windows \\
Vista \\
Home \\
Premium \\
Full \\
Version
\end{tabular} & $\begin{array}{l}\text { http://www. } \\
\text { microsoft.co } \\
\text { m/windows/ } \\
\text { products/win } \\
\text { dowsvista/ed } \\
\text { itions/homep } \\
\text { remium/defa } \\
\text { ult.mspx } \\
\text { (last visited } \\
\text { Mar. 31, } \\
\text { 2008) }\end{array}$ & $\begin{array}{l}\text { With } \\
\text { Windows } \\
\text { Meeting } \\
\text { Space, you } \\
\text { can wirelessly } \\
\text { connect your } \\
\text { mobile PC to } \\
\text { a friend's PC } \\
\text { and share } \\
\text { photos, } \\
\text { videos, and } \\
\text { documents } \\
\text { when you're } \\
\text { at a coffee } \\
\text { shop, working } \\
\text { on a group } \\
\text { project, or in } \\
\text { many other } \\
\text { situationsCeve } \\
n \text { when you're } \\
\text { not connected } \\
\text { to the Internet. }\end{array}$ & \begin{tabular}{|lr|} 
NO & OTHER \\
WARRANTIES. & THE \\
LIMITED WARRANTY IS \\
THE ONLY & DIRECT \\
WARRANTY & FROM \\
MICROSOFT. MICROSOFT \\
MIVES NO & OTHER \\
GIVES & OXPRESS WARRANTIES, \\
\multicolumn{2}{|l}{ GUARANTEES } \\
CONDITIONS.
\end{tabular} & $\begin{array}{l}\text { A. LIMITED WARRANTY. } \\
\text { If you follow the instructions } \\
\text { and the software is properly } \\
\text { licensed, the software will } \\
\text { perform substantially as } \\
\text { described in the Microsoft } \\
\text { materials that you receive in } \\
\text { or with the software. B. } \\
\text { TERM OF WARRANTY; } \\
\text { WARRANTY RECIPIENT; } \\
\text { LENGTH OF ANY IMPLIED } \\
\text { WARRANTIES. The limited } \\
\text { warranty covers the software } \\
\text { for one year after acquired by } \\
\text { the first user. }\end{array}$ \\
\hline 58 & Adobe & \begin{tabular}{|l|} 
Adobe \\
Photoshop \\
Elements \\
5.0
\end{tabular} & $\begin{array}{l}\text { No Longer } \\
\text { available on } \\
\text { Adobe.com }\end{array}$ & \begin{tabular}{|l|} 
Photoshop \\
Elements \\
eliminates red \\
eye \\
automatically \\
as you \\
download \\
photos from \\
your camera.
\end{tabular} & $\begin{array}{l}\ldots \text { the Software and access } \\
\text { to any websites, online } \\
\text { services and CD Services as- } \\
\text { is and with all faults and } \\
\text { expressly disclaim all other } \\
\text { warranties, conditions, } \\
\text { representations or terms, } \\
\text { express or implied, whether } \\
\text { by statute, common law, } \\
\text { custom, usage or otherwise.. } \\
\text {. }\end{array}$ & $\begin{array}{l}\text { 6. LIMITED WARRANTY. } \\
\text { Except as may be otherwise } \\
\text { provided in Section } 14 \text {, Adobe } \\
\text { warrants to the individual or } \\
\text { entity that first purchases a } \\
\text { license for the Software for } \\
\text { use pursuant to the terms of } \\
\text { this agreement that the } \\
\text { Software will perform } \\
\text { substantially in accordance } \\
\text { with the Documentation for } \\
\text { the ninety (90) day period } \\
\text { following receipt of the } \\
\text { Software when used on the } \\
\text { recommended operating } \\
\text { system and hardware } \\
\text { configuration. Non-substantial } \\
\text { variation of performance from } \\
\text { the Documentation does not } \\
\text { establish a warranty right. }\end{array}$ \\
\hline
\end{tabular}




\begin{tabular}{|c|c|c|c|c|c|c|}
\hline 61 & Symantec & \begin{tabular}{|l} 
Norton \\
$360 \quad$ All- \\
In-One \\
Annual \\
Subscripti \\
on - 3 PCs
\end{tabular} & $\begin{array}{l}\text { http://shop.s } \\
\text { ymantecstor } \\
\text { e.com/DRH } \\
\text { M/servlet/Co } \\
\text { ntrollerServl } \\
\text { et?Action=D } \\
\text { isplayProduc } \\
\text { tDetailsPage } \\
\text { \&SiteID=sy } \\
\text { mnahho\&Lo } \\
\text { cale=en_US } \\
\text { \&ThemeID= } \\
\text { 106300\&En } \\
\text { v=BASE\&pr } \\
\text { oductID=81 } \\
\text { 884500 } \\
\text { (last visited } \\
\text { Mar. } 31, \\
\text { 2008) }\end{array}$ & $\begin{array}{l}\text { Provides one- } \\
\text { click access to } \\
\text { expert support } \\
\text { right from } \\
\text { your Norton } \\
\text { product. }\end{array}$ & 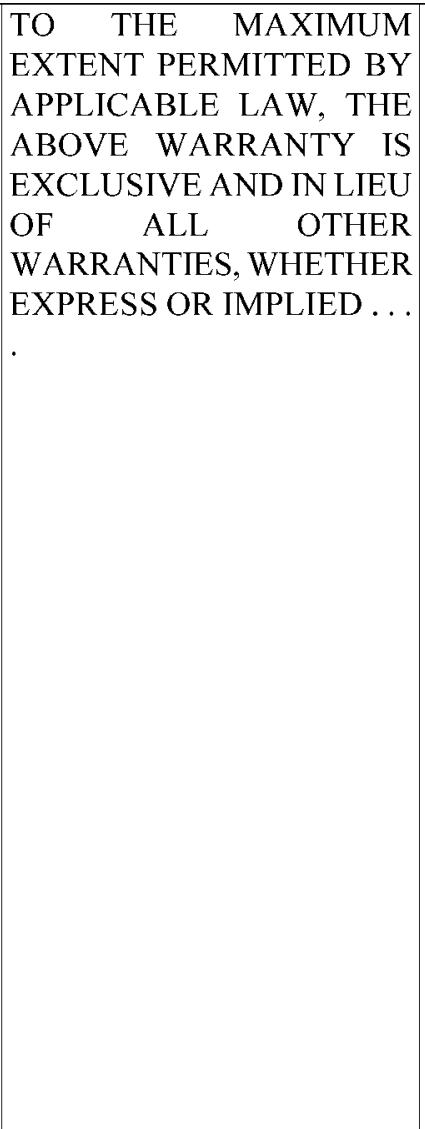 & $\begin{array}{l}\text { 8. Limited Warranty: } \\
\text { Symantec warrants that the } \\
\text { media on which the Software } \\
\text { is distributed will be free from } \\
\text { defects for a period of sixty } \\
\text { (60) days from the date of } \\
\text { delivery of the Software to } \\
\text { You. Your sole remedy in the } \\
\text { event of a breach of this } \\
\text { warranty will be that } \\
\text { Symantec will, at its option, } \\
\text { replace any defective media } \\
\text { returned to Symantec within } \\
\text { the warranty period or refund } \\
\text { the money You paid for the } \\
\text { Software. Symantec does not } \\
\text { warrant that the Software will } \\
\text { meet Your requirements or } \\
\text { that operation of the Software } \\
\text { will be uninterrupted or that } \\
\text { the Software will be error- } \\
\text { free. For the avoidance of } \\
\text { doubt, references to } \\
\text { "Software" in the foregoing } \\
\text { sentence shall include, but not } \\
\text { be limited to, the Online } \\
\text { Backup Feature and Technical } \\
\text { Support. }\end{array}$ \\
\hline 62 & Microsoft & $\begin{array}{l}\text { Microsoft } \\
\text { Office } \\
\text { Profession } \\
\text { al } 2003\end{array}$ & $\begin{array}{l}\text { http://www. } \\
\text { microsoft.co } \\
\mathrm{m} / \text { products/i } \\
\text { nfo/product. } \\
\text { aspx?view }=2 \\
\text { 2\&type=ovr } \\
\text { \&pcid=ee95 } \\
9 \text { bd8-14b4- } \\
4601-91 \text { a7- } \\
\text { eea1043249f } \\
\text { a\#Overview }\end{array}$ & $\begin{array}{l}\text { Support for } \\
\text { industry- } \\
\text { standard } \\
\text { Extensible } \\
\text { Markup } \\
\text { Language } \\
\text { (XML) lets } \\
\text { you exchange } \\
\text { and use data } \\
\text { from a variety } \\
\text { of sources. }\end{array}$ & $\begin{array}{l}\text { DISCLAIMER OF } \\
\text { WARRANTIES. The Limited } \\
\text { Warranty that appears above } \\
\text { is the only express warranty } \\
\text { made to you and is provided } \\
\text { in lieu of any other express } \\
\text { warranties or similar } \\
\text { obligations (if any) created } \\
\text { by any advertising, } \\
\text { documentation, packaging, or } \\
\text { other communications. }\end{array}$ & $\begin{array}{l}\text { 16. LIMITED WARRANTY } \\
\text { FOR SOFTWARE } \\
\text { ACQUIRED IN THE US } \\
\text { AND CANADA. Microsoft } \\
\text { warrants that the Software will } \\
\text { perform substantially in } \\
\text { accordance with the } \\
\text { accompanying materials for a } \\
\text { period of ninety }(90) \text { days } \\
\text { from the date of receipt. }\end{array}$ \\
\hline
\end{tabular}




\begin{tabular}{|c|c|c|c|c|c|c|}
\hline 63 & Intuit & \begin{tabular}{|lr|}
\multicolumn{2}{|c|}{ Quickboo } \\
ks & Pro \\
2007 & for \\
Mac &
\end{tabular} & $\begin{array}{l}\text { http://quickb } \\
\text { ooks.intuit.c } \\
\text { om/product/ } \\
\text { accounting- } \\
\text { software/pro } \\
\text {-mac- } \\
\text { business- } \\
\text { finance- } \\
\text { software.jht } \\
\text { ml } \\
\text { (last visited } \\
\text { Mar. 31, } \\
\text { 2008) }\end{array}$ & $\begin{array}{l}\text { Click a button } \\
\text { to turn any } \\
\text { invoice, } \\
\text { estimate, } \\
\text { purchase order } \\
\text { or report into } \\
\text { a PDF file. }\end{array}$ & 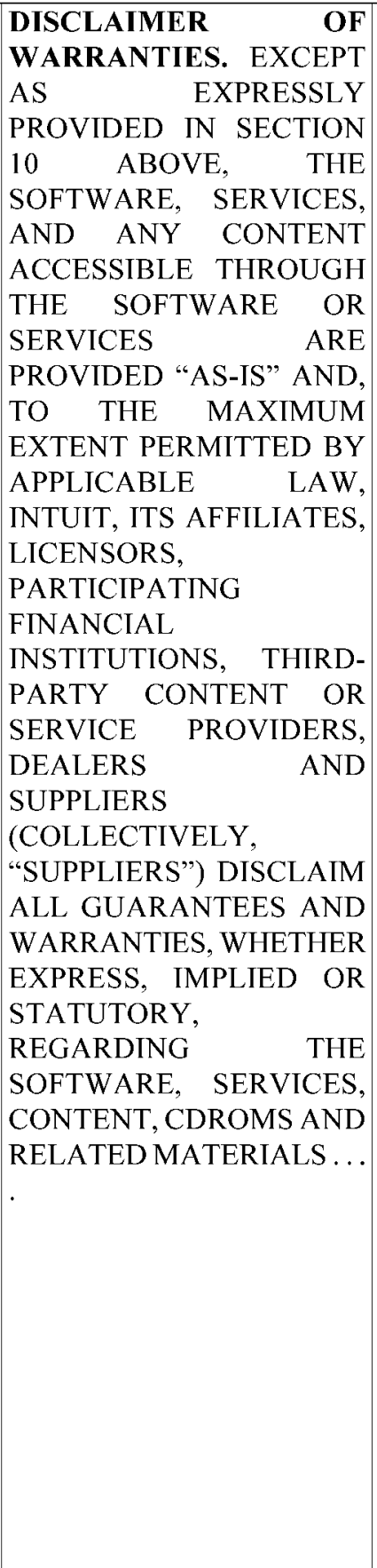 & $\begin{array}{l}\text { 10. SATISFACTION } \\
\text { GUARANTEED/LIMITED } \\
\text { WARRANTY. (i) } \\
\text { Satisfaction Guarantee. If you } \\
\text { are not satisfied with the } \\
\text { Software and (a) You } \\
\text { purchased the Software from a } \\
\text { retail store, you may uninstall } \\
\text { and delete all copies of the } \\
\text { Software from your } \\
\text { computer(s) and return it } \\
\text { within } 60 \text { days of purchase to } \\
\text { the store where you purchased } \\
\text { your license with a dated } \\
\text { receipt for a full refund. If the } \\
\text { store is unable or unwilling to } \\
\text { issue a refund or you obtained } \\
\text { the Software directly from } \\
\text { Intuit, you may uninstall and } \\
\text { delete all copies of the } \\
\text { Software and return the } \\
\text { Software with a dated receipt } \\
\text { or packing slip within } 60 \text { days } \\
\text { of purchase via U.S. mail to } \\
\text { Intuit Inc., Returns } \\
\text { Department, PO Box } 190004 \text {, } \\
\text { Greenville, SC } 29390-9004 \text { or } \\
\text { via UPS to Intuit Inc., Returns } \\
\text { Department, 110 Hidden Lake } \\
\text { Circle, Duncan, SC } 29334 . . . \\
\text { (ii) Limited Warranty. (a) If } \\
\text { the CDROM on which the } \\
\text { Software is stored is defective, } \\
\text { then return the CDROM to } \\
\text { Intuit Inc., Returns } \\
\text { Department, PO Box } 19004, \\
\text { Greenville, SC 29390-9004 } \\
\text { within } 60 \text { days of shipment (or } \\
\text { in the case of a retail purchase, } \\
\text { within } 60 \text { days of purchase) } \\
\text { with a dated receipt or packing } \\
\text { slip, and a replacement } \\
\text { CDROM will be mailed to } \\
\text { you .... }\end{array}$ \\
\hline
\end{tabular}


11 Yale J.L. \& Tech. 1 (2009)

\begin{tabular}{|c|c|c|c|c|c|c|}
\hline 64 & $\begin{array}{l}\text { Trend } \\
\text { Micro }\end{array}$ & $\begin{array}{l}\text { Trend } \\
\text { Micro } \\
\text { Internet } \\
\text { Security } \\
2008 \\
\text { User }\end{array}$ & $\begin{array}{l}\text { http://www.i } \\
\text { nternetsecuri } \\
\text { ty- } \\
\text { 2008.com/pc } \\
\text {-cillin.html }\end{array}$ & $\begin{array}{l}\text { Parental } \\
\text { controls give } \\
\text { you control } \\
\text { over your } \\
\text { children's } \\
\text { internet } \\
\text { activity by } \\
\text { blocking } \\
\text { inappropriate } \\
\text { Web sites and } \\
\text { content. }\end{array}$ & $\begin{array}{l}\text { NO OTHER WARRANTIES } \\
\text { OR REMEDIES. EXCEPT } \\
\text { FOR THE EXPRESS } \\
\text { LIMITED WARRANTY IN } \\
\text { SECTION 10, THE TERMS } \\
\text { OF THIS AGREEMENT } \\
\text { ARE IN LIEU OF ALL } \\
\text { WARRANTIES, (EXPRESS } \\
\text { OR IMPLIED), } \\
\text { CONDITIONS, } \\
\text { UNDERTAKINGS ... }\end{array}$ & 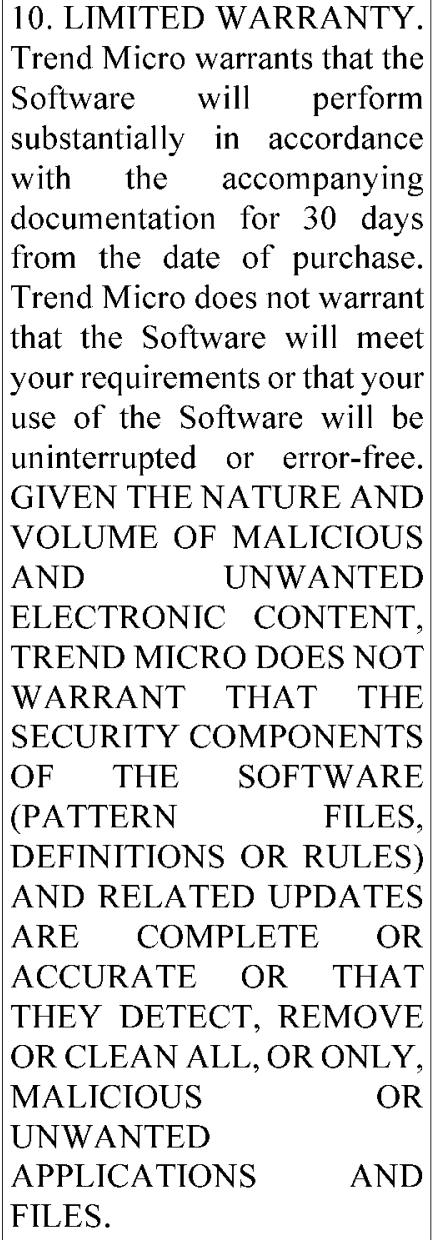 \\
\hline
\end{tabular}




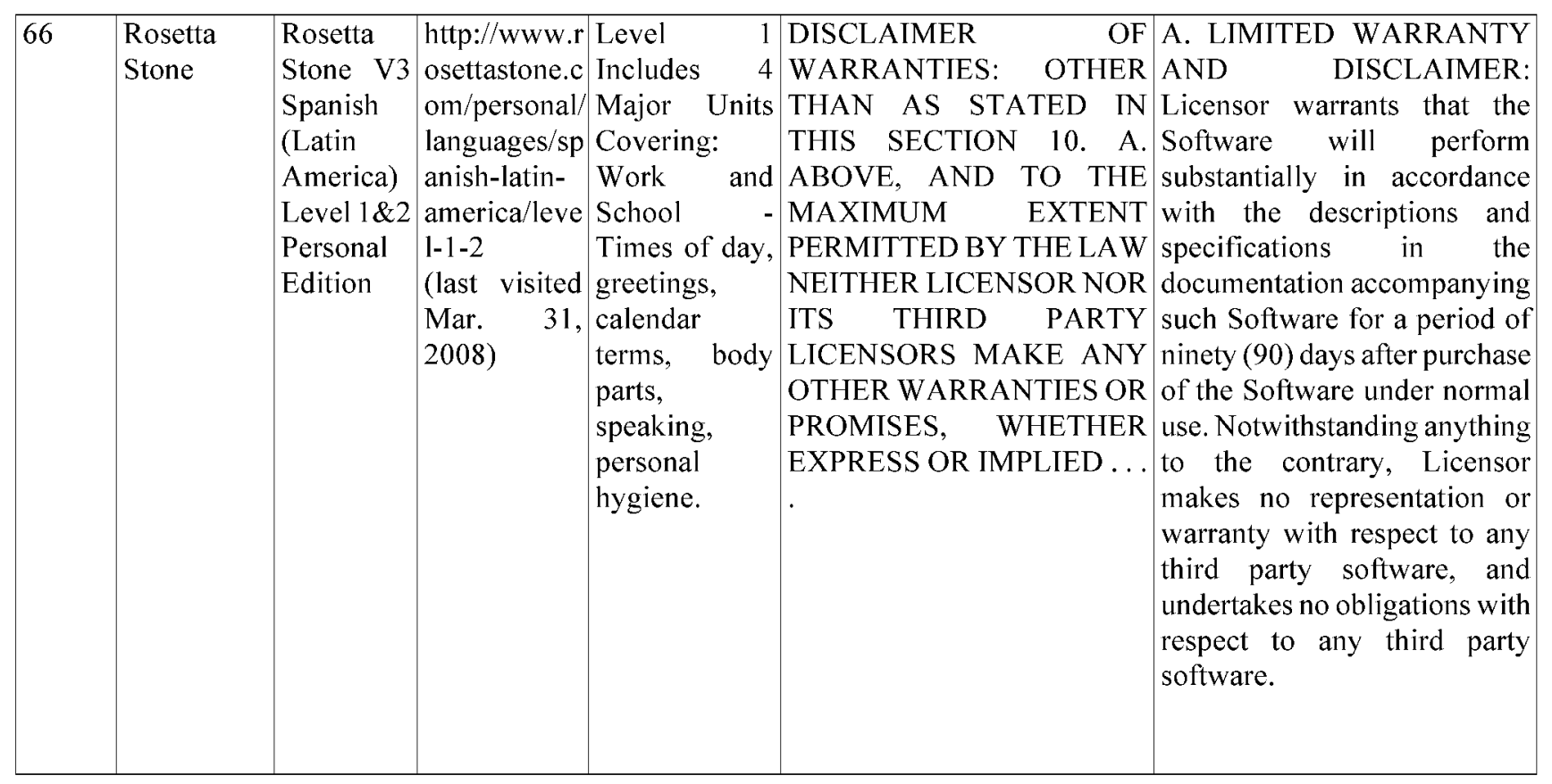




\begin{tabular}{|c|c|c|c|c|c|c|}
\hline 67 & Final Draft & \begin{tabular}{|l|} 
Final \\
Draft $\quad 7$ \\
Profession \\
al \\
Scriptwriti \\
ng
\end{tabular} & $\begin{array}{l}\text { http://finaldr } \\
\text { aft.com/prod } \\
\text { ucts/final- } \\
\text { draft/whats- } \\
\text { i new.php }\end{array}$ & 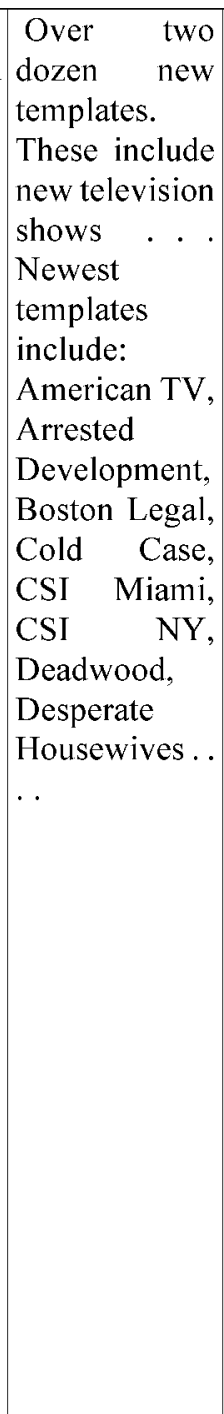 & 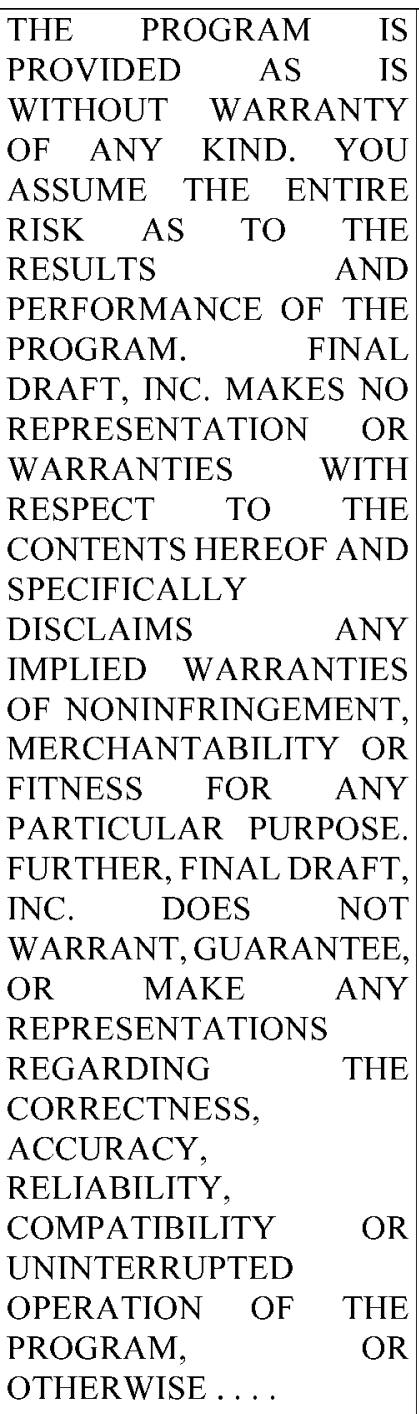 & 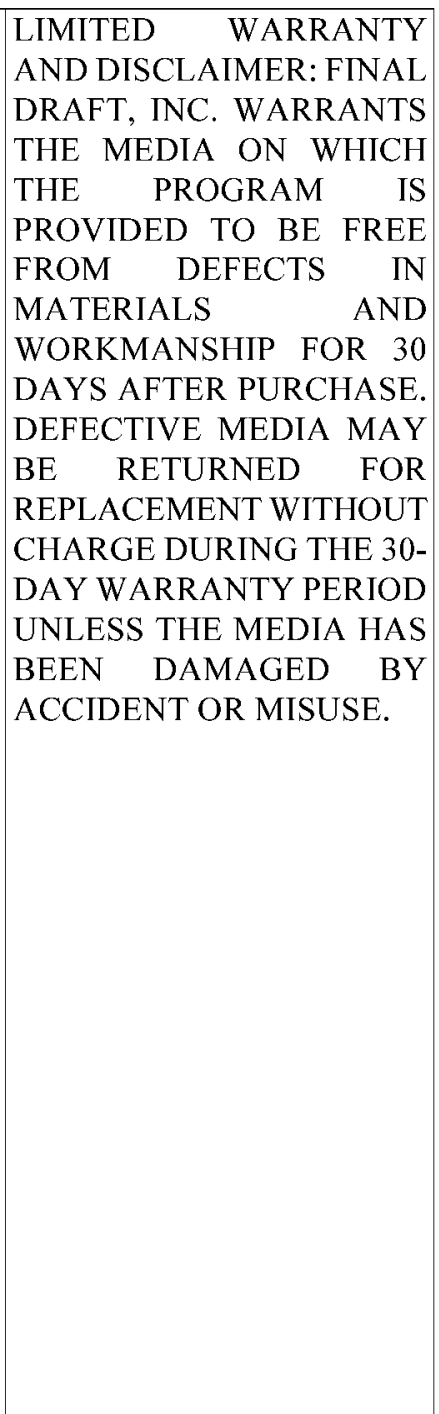 \\
\hline
\end{tabular}




\section{Warranties and Disclaimers in the Electronic Age}

\begin{tabular}{|c|c|c|c|c|c|c|}
\hline 70 & Adobe & \begin{tabular}{|l|} 
Adobe \\
Photoshop \\
CS2
\end{tabular} & $\begin{array}{l}\text { No longer } \\
\text { available on } \\
\text { www.adobe. } \\
\text { com }\end{array}$ & $\begin{array}{l}\text { No longer } \\
\text { available on } \\
\text { www.adobe.c } \\
\text { om }\end{array}$ & $\begin{array}{l}\ldots \text { the Software and access } \\
\text { to any websites, online } \\
\text { services and CD Services as- } \\
\text { is and with all faults and } \\
\text { expressly disclaim all other } \\
\text { warranties, conditions, } \\
\text { representations or terms, } \\
\text { express or implied, whether } \\
\text { by statute, common law, } \\
\text { custom, usage or otherwise.. } \\
\text {. }\end{array}$ & $\begin{array}{l}\text { 6. LIMITED WARRANTY. } \\
\text { Except as may be otherwise } \\
\text { provided in Section } 14 \text {, Adobe } \\
\text { warrants to the individual or } \\
\text { entity that first purchases a } \\
\text { license for the Software for } \\
\text { use pursuant to the terms of } \\
\text { this agreement that the } \\
\text { Software will perform } \\
\text { substantially in accordance } \\
\text { with the Documentation for } \\
\text { the ninety (90) day period } \\
\text { following receipt of the } \\
\text { Software when used on the } \\
\text { recommended operating } \\
\text { system and hardware } \\
\text { configuration. Non-substantial } \\
\text { variation of performance from } \\
\text { the Documentation does not } \\
\text { establish a warranty right. }\end{array}$ \\
\hline
\end{tabular}




\begin{tabular}{|c|c|c|c|c|c|c|}
\hline 73 & Intuit & $\begin{array}{l}\text { Quickboo } \\
\text { ks } \\
\text { Premiere } \\
\text { Edition } \\
2008\end{array}$ & $\begin{array}{l}\text { http://quickb } \\
\text { ooks.intuit.c } \\
\text { om/product/ } \\
\text { accounting- } \\
\text { software/pre } \\
\text { mier-edition- } \\
\text { financial- } \\
\text { planning- } \\
\text { software.jht } \\
\text { ml?lid=left } \\
\text { nav } \\
\text { (last visited } \\
\text { Mar. 31, } \\
\text { 2008) }\end{array}$ & \begin{tabular}{|l} 
Track \\
inventory, set \\
reorder points \\
$\& \quad$ create \\
purchase \\
orders.
\end{tabular} & 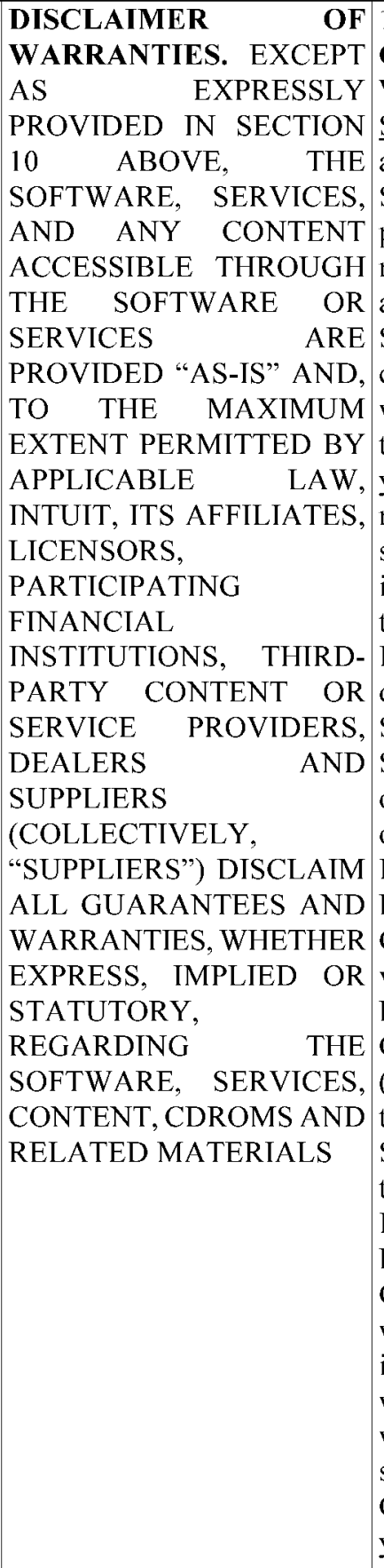 & $\begin{array}{l}\text { 10. SATISFACTION } \\
\text { GUARANTEED/LIMITED } \\
\text { WARRANTY. (i) } \\
\text { Satisfaction Guarantee. If you } \\
\text { are not satisfied with the } \\
\text { Software and (a) You } \\
\text { purchased the Software from a } \\
\text { retail store, you may uninstall } \\
\text { and delete all copies of the } \\
\text { Software from your } \\
\text { computer(s) and return it } \\
\text { within } 60 \text { days of purchase to } \\
\text { the store where you purchased } \\
\text { your license with a dated } \\
\text { receipt for a full refund. If the } \\
\text { store is unable or unwilling to } \\
\text { issue a refund or you obtained } \\
\text { the Software directly from } \\
\text { Intuit, you may uninstall and } \\
\text { delete all copies of the } \\
\text { Software and return the } \\
\text { Software with a dated receipt } \\
\text { or packing slip within } 60 \text { days } \\
\text { of purchase via U.S. mail to } \\
\text { Intuit Inc., Returns } \\
\text { Department, PO Box } 190004, \\
\text { Greenville, SC } 29390-9004 \text { or } \\
\text { via UPS to Intuit Inc., Returns } \\
\text { Department, } 110 \text { Hidden Lake } \\
\text { Circle, Duncan, SC } 29334 . . . \\
\text { (ii) Limited Warranty. (a) If } \\
\text { the CDROM on which the } \\
\text { Software is stored is defective, } \\
\text { then return the CDROM to } \\
\text { Intuit Inc., Returns } \\
\text { Department, PO Box } 19004, \\
\text { Greenville, SC 29390-9004 } \\
\text { within } 60 \text { days of shipment (or } \\
\text { in the case of a retail purchase, } \\
\text { within } 60 \text { days of purchase) } \\
\text { with a dated receipt or packing } \\
\text { slip, and a replacement } \\
\text { CDROM will be mailed to } \\
\text { you ... }\end{array}$ \\
\hline
\end{tabular}




\begin{tabular}{|c|c|c|c|c|c|c|}
\hline 75 & Intuit & $\begin{array}{l}\text { Quicken } \\
2008 \\
\text { Home \& } \\
\text { Business }\end{array}$ & $\begin{array}{l}\text { http://quicke } \\
\text { n.intuit.com/ } \\
\text { small- } \\
\text { business- } \\
\text { finance/hom } \\
\text { e- } \\
\text { business.jht } \\
\text { ml?cid=ppc } \\
\text { google b_all } \\
\text { stan_US_P } \\
\text { FS+- } \\
\text { +H\&priority } \\
\text { Code=39789 } \\
00000 \\
\text { (last visited } \\
\text { Mar. } 31 \text {, } \\
\text { 2008) }\end{array}$ & $\begin{array}{l}\text { Whether it's } \\
\text { personal } \\
\text { payments or } \\
\text { business } \\
\text { income -- or } \\
\text { both -- } \\
\text { Quicken can } \\
\text { now import } \\
\text { your } \\
\text { transaction } \\
\text { data directly } \\
\text { from PayPal. }\end{array}$ & $\begin{array}{lr}\text { G. DISCLAIM } & \text { ALL } \\
\text { GUARANTEES } & \text { AND } \\
\text { WARRANTIES, WHETHER } \\
\text { EXPRESS, IMPLIED OR } \\
\text { STATUTORY, } \\
\text { REGARDING } \\
\text { SOFTWARE, FINANCIAL } \\
\text { INSTITUTION SERVICES, } \\
\text { THIRD PARTY SERVICES, } \\
\text { CONTENT, AND } \\
\text { RELATED MATERIALS, } \\
\text { INCLUDING A ANY } \\
\text { WARRANTY OF FITNESS } \\
\text { FOR A PARTICULAR } \\
\text { PURPOSE, TITLE, } \\
\text { MERCHANTABILITY, } \\
\text { AND } \\
\text { INFRINGEMENT. NON- }\end{array}$ & $\begin{array}{l}\text { 9. SATISFACTION } \\
\text { GUARANTEED. If you are } \\
\text { not satisfied with the Software } \\
\text { and (a) You purchased the } \\
\text { Software from a retail store, } \\
\text { you may uninstall and delete } \\
\text { all copies of the Software } \\
\text { from your computer(s) and } \\
\text { return it within } 60 \text { days of } \\
\text { purchase to the store where } \\
\text { you purchased your license } \\
\text { with a dated receipt for a full } \\
\text { refund. If the store is unable or } \\
\text { unwilling to issue a refund or } \\
\text { you obtained the Software } \\
\text { directly from Intuit, you may } \\
\text { uninstall and delete all copies } \\
\text { of the Software and return the } \\
\text { Software with a dated receipt } \\
\text { or packing slip within } 60 \text { days } \\
\text { of purchase via U.S. mail to } \\
\text { Intuit Inc., Returns } \\
\text { Department, PO Box } 190004, \\
\text { Greenville, SC } 29390-9004 \text { or } \\
\text { via UPS to Intuit Inc., Returns } \\
\text { Department, 110 Hidden Lake } \\
\text { Circle, Duncan, SC } 29334 \text {. (b) } \\
\text { You obtained the Software } \\
\text { directly from Intuit via an } \\
\text { Internet download, you may } \\
\text { submit a written request to } \\
\text { Intuit including your name, } \\
\text { contact and product order } \\
\text { information to Intuit Inc., } \\
\text { Returns Department, PO Box } \\
19004 \text {, Greenville, SC } 29390- \\
9004 .\end{array}$ \\
\hline
\end{tabular}


11 Yale J.L. \& Tech. 1 (2009)

\begin{tabular}{|c|c|c|c|c|c|c|}
\hline \begin{tabular}{|l|}
79 \\
\end{tabular} & $\begin{array}{l}\text { Sony } \\
\text { Media }\end{array}$ & \begin{tabular}{|l|} 
Vegas \\
Movie \\
Studio 8 \\
Platinum \\
Edition
\end{tabular} & $\begin{array}{l}\text { http://www.s } \\
\text { onycreatives } \\
\text { oftware.com } \\
\text { /products/pr } \\
\text { oduct.asp?pi } \\
\text { d=447 } \\
\text { (last visited } \\
\text { Mar. 31, } \\
\text { 2008) }\end{array}$ & $\begin{array}{l}\text { Over } 100 \\
\text { video effects } \\
\text { and transitions } \\
\text { from } \\
\text { NewBlue7, } \\
\text { maker of } \\
\text { professional } \\
\text { video effects } \\
\text { plug-ins. }\end{array}$ & 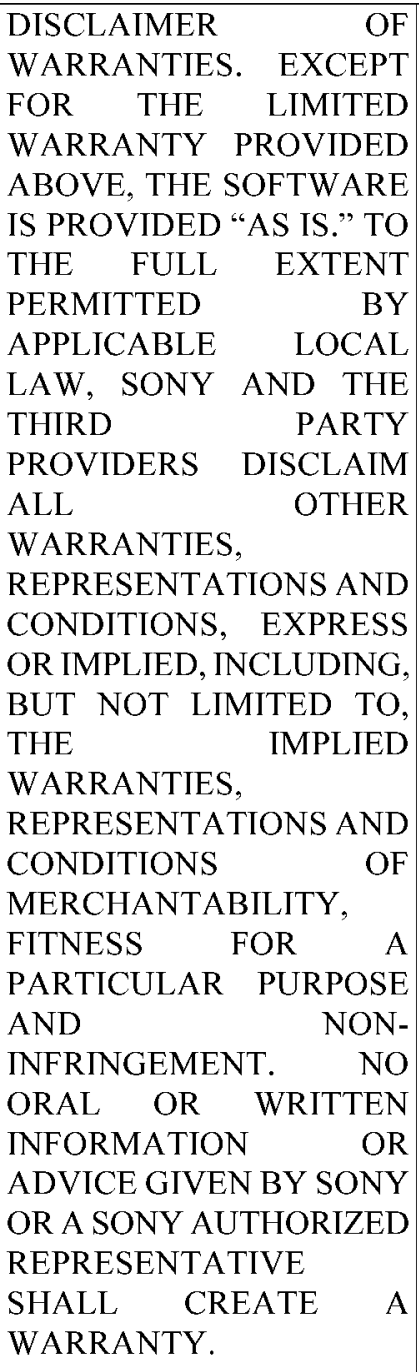 & $\begin{array}{l}\text { No limited warranty despite } \\
\text { the language in the disclaimer. }\end{array}$ \\
\hline
\end{tabular}




\begin{tabular}{|c|c|c|c|c|c|c|}
\hline 81 & Microsoft & \begin{tabular}{|l|} 
Microsoft \\
Office \\
Small \\
Business \\
2007 \\
Upgrade \\
\end{tabular} & $\begin{array}{l}\text { http://office. } \\
\text { microsoft.co } \\
\text { m/en- } \\
\text { us/help/HA1 } \\
0198308103 \\
3 . a s p x\end{array}$ & $\begin{array}{l}\text { With } \\
\text { SmartArt } \\
\text { graphics, you } \\
\text { can } \\
\text { experiment as } \\
\text { much as you } \\
\text { want with } \\
\text { different } \\
\text { formats and } \\
\text { styles. You } \\
\text { can preview } \\
\text { styles before } \\
\text { choosing one, } \\
\text { so you don't } \\
\text { have to apply } \\
\text { styles over } \\
\text { and over again } \\
\text { to find the one } \\
\text { you want. }\end{array}$ & \begin{tabular}{|lr|} 
NO & OTHER \\
WARRANTIES. & THE \\
LIMITED WARRANTY IS \\
THE ONLY & DIRECT \\
WARRANTY & FROM \\
MICROSOFT. MICROSOFT \\
GIVES NO & OTHER \\
GXPRESS & WARRANTIES, \\
\multicolumn{2}{l}{ GUARANTEES } \\
CONDITIONS.
\end{tabular} & $\begin{array}{l}\text { LIMITED WARRANTY. If } \\
\text { you follow the instructions, } \\
\text { the software will perform } \\
\text { substantially as described in } \\
\text { the Microsoft materials that } \\
\text { you receive in or with the } \\
\text { software. }\end{array}$ \\
\hline$\overline{83}$ & Microsoft & \begin{tabular}{|l|} 
Microsoft \\
Windows \\
Vista \\
Ultimate \\
Full \\
Version
\end{tabular} & $\begin{array}{l}\text { http://www. } \\
\text { microsoft.co } \\
\text { m/windows/ } \\
\text { products/win } \\
\text { dowsvista/fe } \\
\text { atures/details } \\
\text { /flip3d.mspx }\end{array}$ & $\begin{array}{l}\text { Windows Flip } \\
\text { and Windows } \\
\text { Flip 3D render } \\
\text { live thumbnail } \\
\text { images of the } \\
\text { exact contents } \\
\text { of your open } \\
\text { windows. }\end{array}$ & 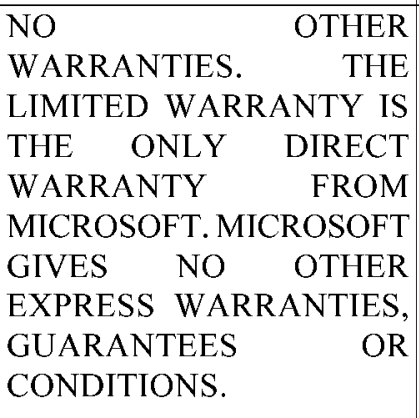 & $\begin{array}{l}\text { A. LIMITED WARRANTY. } \\
\text { If you follow the instructions } \\
\text { and the software is properly } \\
\text { licensed, the software will } \\
\text { perform substantially as } \\
\text { described in the Microsoft } \\
\text { materials that you receive in } \\
\text { or with the software }\end{array}$ \\
\hline 84 & $\begin{array}{l}\text { Palo Alto } \\
\text { Software }\end{array}$ & $\begin{array}{ll}\text { Palo } & \text { Alto } \\
\text { Business } \\
\text { Plan } & \text { Pro } \\
2007 & \end{array}$ & $\begin{array}{l}\text { http://www. } \\
\text { paloalto.com } \\
\text { /ps/bp/?bped } \\
\text { ition=bpp } \\
\text { (last visited } \\
\text { Mar. } 31, \\
2008 \text { ) }\end{array}$ & $\begin{array}{l}500+\text { sample } \\
\text { business } \\
\text { plans. }\end{array}$ & $\begin{array}{lrr}\text { TO } & \text { THE } & \text { EXTENT } \\
\text { PERMITTED } & \text { BY } \\
\text { APPLICABLE } & \text { LAW } & \text { AND } \\
\text { EXCEPT AS EXPRESSLY } \\
\text { PROVIDED ABOVE, THE } \\
\text { SOFTWARE IS } & \text { "AS-IS" } \\
\text { AND } & \text { PALO } & \text { ALTO } \\
\text { SOFTWARE, INC. } & . \\
\text { DISCLAIM[S] } & \text { ALL } \\
\text { WARRANTIES, } & \text { EXPRESS } \\
\text { OR } & \text { IMPLIED, } \\
\text { REGARDING } & \text { THE } \\
\text { SOFTWARE, DISK } & \text { AND } \\
\text { RELATED MATERIALS ... }\end{array}$ & $\begin{array}{l}\text { No limited warranty despite } \\
\text { the language in the disclaimer. }\end{array}$ \\
\hline
\end{tabular}




\begin{tabular}{|c|c|c|c|c|c|c|}
\hline 86 & $\begin{array}{l}\text { Rosetta } \\
\text { Stone }\end{array}$ & \begin{tabular}{|l|} 
Rosetta \\
Stone V3 \\
French \\
Level 1\&2 \\
Personal \\
Edition
\end{tabular} & $\begin{array}{l}\text { http://Www.r } \\
\text { osettastone.c } \\
\text { om/personal/ } \\
\text { languages/fr } \\
\text { ench/level-1- } \\
2 \\
\text { (last visited } \\
\text { Mar. } 31 \text {, } \\
2008 \text { ) }\end{array}$ & $\begin{array}{l}\text { Level 1 \& } 2 \\
\text { Set Includes: } \\
\text { Friends and } \\
\text { Social Life - } \\
\text { Months of the } \\
\text { year, arrivals } \\
\text { and } \\
\text { departures, } \\
\text { social } \\
\text { interaction, } \\
\text { celebrations, } \\
\text { meal courses, } \\
\text { quality terms, } \\
\text { apologies. }\end{array}$ & $\begin{array}{|lrr|}\text { DISCLAIMER } & & \text { OF } \\
\text { WARRANTIES: } & \text { OTHER } \\
\text { THAN AS } & \text { STATED } & \text { IN } \\
\text { THIS SECTION } & 10 . & \text { A. } \\
\text { ABOVE, AND } & \text { TO } & \text { THE } \\
\text { MAXIMUM } & \text { EXTENT } \\
\text { PERMITTED BY THE LAW } \\
\text { NEITHER LICENSOR NOR } \\
\text { ITS } & \text { THIRD } & \text { PARTY } \\
\text { LICENSORS MAKE ANY } \\
\text { OTHER WARRANTIES OR } \\
\text { PROMISES, r WHETHER } \\
\text { EXPRESS OR IMPLIED ... }\end{array}$ & $\begin{array}{l}\text { A. LIMITED WARRANTY } \\
\text { AND DISCLAIMER: } \\
\text { Licensor warrants that the } \\
\text { Software will perform } \\
\text { substantially in accordance } \\
\text { with the descriptions and } \\
\text { specifications in the } \\
\text { documentation accompanying } \\
\text { such Software for a period of } \\
\text { ninety (90) days after purchase } \\
\text { of the Software under normal } \\
\text { use. Notwithstanding anything } \\
\text { to the contrary, Licensor } \\
\text { makes no representation or } \\
\text { warranty with respect to any } \\
\text { third party software, and } \\
\text { undertakes no obligations with } \\
\text { respect to any third party } \\
\text { software. }\end{array}$ \\
\hline 89 & Microsoft & \begin{tabular}{|l|} 
Microsoft \\
Visual \\
Studio \\
Standard \\
2005
\end{tabular} & $\begin{array}{l}\text { http://msdn2 } \\
\text {.microsoft.co } \\
\text { m/en- } \\
\text { us/vs2005/aa } \\
718671 . a s p x\end{array}$ & $\begin{array}{l}\text { Support for } \\
\text { Visual Basic, } \\
\mathrm{CH}, \mathrm{C}++ \text {, and } \\
\mathrm{J} \# \text { languages. }\end{array}$ & $\begin{array}{lrr}\text { NO } & \text { OTHER } \\
\text { WARRANTIES. } & \text { THE } \\
\text { LIMITED WARRANTY IS } \\
\text { THE ONLY } & \text { DIRECT } \\
\text { WARRANTY } & \text { FROM } \\
\text { MICROSOFT. MICROSOFT } \\
\text { GIVES NO } & \text { OTHER } \\
\text { EXPRESS } & \text { WARRANTIES, } \\
\text { GUARANTEES } & \text { OR } \\
\text { CONDITIONS. } & \end{array}$ & $\begin{array}{l}\text { A. LIMITED WARRANTY. } \\
\text { If you follow the instructions, } \\
\text { the software will perform } \\
\text { substantially as described in } \\
\text { the Microsoft materials that } \\
\text { you receive in or with the } \\
\text { software. }\end{array}$ \\
\hline
\end{tabular}




\begin{tabular}{|c|c|c|c|c|c|c|}
\hline 93 & Intuit & 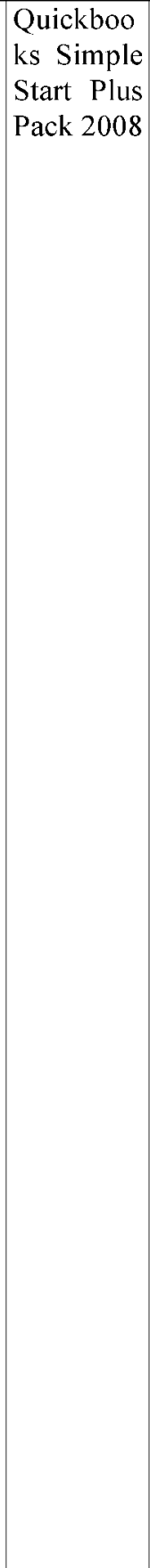 & $\begin{array}{l}\text { http://quickb } \\
\text { ooks.intuit.c } \\
\text { om/product/ } \\
\text { accounting- } \\
\text { software/sim } \\
\text { ple-start- } \\
\text { bookkeeping } \\
\text { - } \\
\text { software.jht } \\
\text { ml } \\
\text { (last visited } \\
\text { Mar. 31, } \\
\text { 2008) }\end{array}$ & 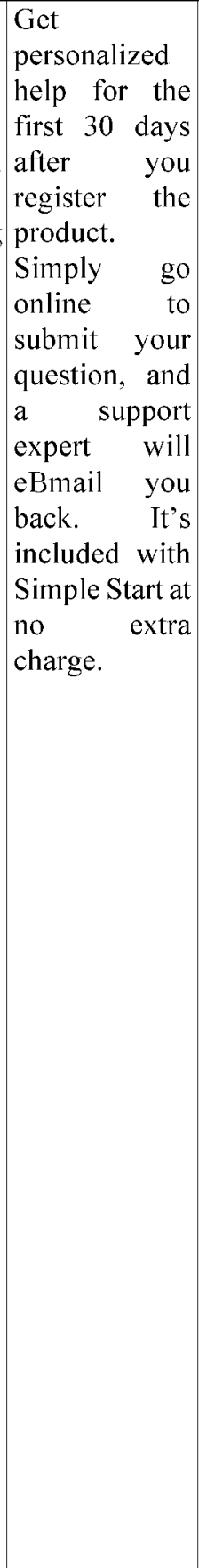 & 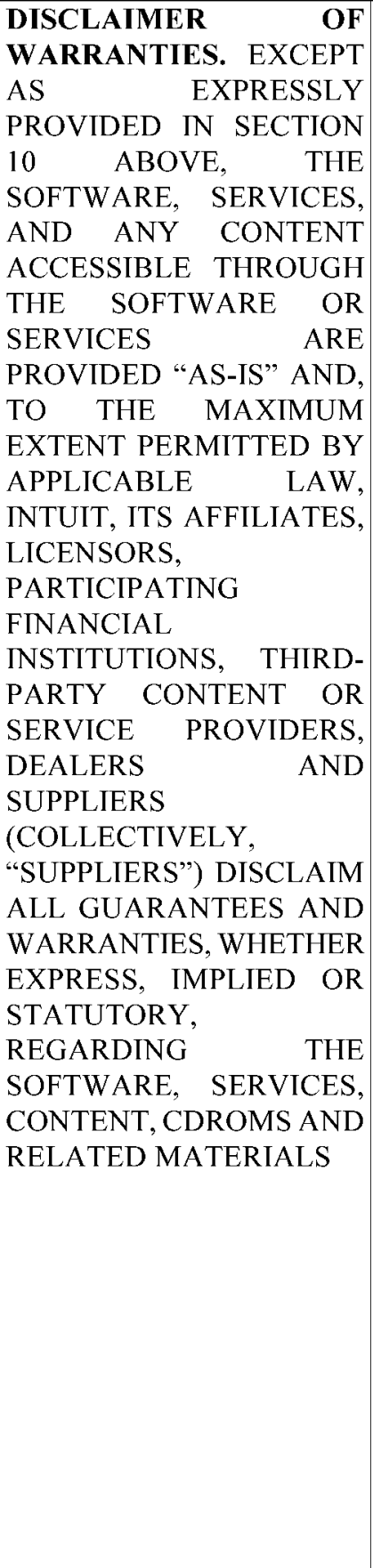 & $\begin{array}{l}\text { 10. SATISFACTION } \\
\text { GUARANTEED/LIMITED } \\
\text { WARRANTY. (i) } \\
\text { Satisfaction Guarantee. If you } \\
\text { are not satisfied with the } \\
\text { Software and (a) You } \\
\text { purchased the Software from a } \\
\text { retail store, you may uninstall } \\
\text { and delete all copies of the } \\
\text { Software from your } \\
\text { computer(s) and return it } \\
\text { within } 60 \text { days of purchase to } \\
\text { the store where you purchased } \\
\text { your license with a dated } \\
\text { receipt for a full refund. If the } \\
\text { store is unable or unwilling to } \\
\text { issue a refund or you obtained } \\
\text { the Software directly from } \\
\text { Intuit, you may uninstall and } \\
\text { delete all copies of the } \\
\text { Software and return the } \\
\text { Software with a dated receipt } \\
\text { or packing slip within } 60 \text { days } \\
\text { of purchase via U.S. mail to } \\
\text { Intuit Inc., Returns } \\
\text { Department, PO Box 190004, } \\
\text { Greenville, SC } 29390-9004 \text { or } \\
\text { via UPS to Intuit Inc., Returns } \\
\text { Department, } 110 \text { Hidden Lake } \\
\text { Circle, Duncan, SC } 29334 . \\
\text {...(ii) Limited Warranty. (a) If } \\
\text { the CDROM on which the } \\
\text { Software is stored is defective, } \\
\text { then return the CDROM to } \\
\text { Intuit Inc., Returns } \\
\text { Department, PO Box 19004, } \\
\text { Greenville, SC 29390-9004 } \\
\text { within } 60 \text { days of shipment (or } \\
\text { in the case of a retail purchase, } \\
\text { within } 60 \text { days of purchase) } \\
\text { with a dated receipt or packing } \\
\text { slip, and a replacement } \\
\text { CDROM will be mailed to } \\
\text { you.... }\end{array}$ \\
\hline
\end{tabular}


11 Yale J.L. \& Tech. 1 (2009)

\begin{tabular}{|c|c|c|c|c|c|c|}
\hline 97 & Microsoft & $\begin{array}{l}\text { Microsoft } \\
\text { Expressio } \\
\mathrm{n} \quad \text { Web } \\
\text { Upgrade } \\
\text { from } \\
\text { FrontPage }\end{array}$ & $\begin{array}{l}\text { http://www. } \\
\text { microsoft.co } \\
\text { m/expressio } \\
\text { n/products/fe } \\
\text { atures.aspx? } \\
\text { key=web } \\
\text { (last visited } \\
\text { Mar. 31, } \\
2008)\end{array}$ & $\begin{array}{l}\text { Configure } \\
\text { flexible } \\
\text { schema } \\
\text { settings to } \\
\text { support all } \\
\text { combinations } \\
\text { of HTML, } \\
\text { XHTML, } \\
\text { Strict, } \\
\text { Transitional, } \\
\text { Frameset and } \\
\text { CSS 1.0, 2.0, } \\
\text { and 2.1 plus } \\
\text { browser- } \\
\text { specific } \\
\text { schemas. }\end{array}$ & \begin{tabular}{|lr} 
NO & OTHER \\
WARRANTIES. & THE \\
LIMITED WARRANTY IS \\
THE ONLY \\
WARRART \\
MICROSOFT. MICROSOFT \\
GIVES NO OTHER \\
EXPRESS WARRANTIES, \\
GUARANTEES r OR \\
CONDITIONS.
\end{tabular} & $\begin{array}{l}\text { LIMITED WARRANTY. If } \\
\text { you follow the instructions, } \\
\text { the software will perform } \\
\text { substantially as described in } \\
\text { the Microsoft materials that } \\
\text { you receive in or with the } \\
\text { software. }\end{array}$ \\
\hline
\end{tabular}




\begin{tabular}{|c|c|c|c|c|c|c|}
\hline 99 & Corel & $\begin{array}{l}\text { Corel } \\
\text { Ulead } \\
\text { VideoStud } \\
\text { io } 11 \text { Plus }\end{array}$ & $\begin{array}{l}\text { http://www.c } \\
\text { orel.com/ser } \\
\text { vlet/Satellite } \\
\text { /us/en/Produ } \\
\text { ct/11757142 } \\
28666 \\
\text { (last visited } \\
\text { Mar. 31, } \\
2008 \text { ) }\end{array}$ & $\begin{array}{l}\text { Capture and } \\
\text { import video } \\
\text { from DV, } \\
\text { DVD, } \\
\text { AVCHD or } \\
\text { HDV } \\
\text { camcorders. } \\
\text { Import video } \\
\text { from mobile } \\
\text { devices, VHS } \\
\text { tape or the } \\
\text { Web. }\end{array}$ & 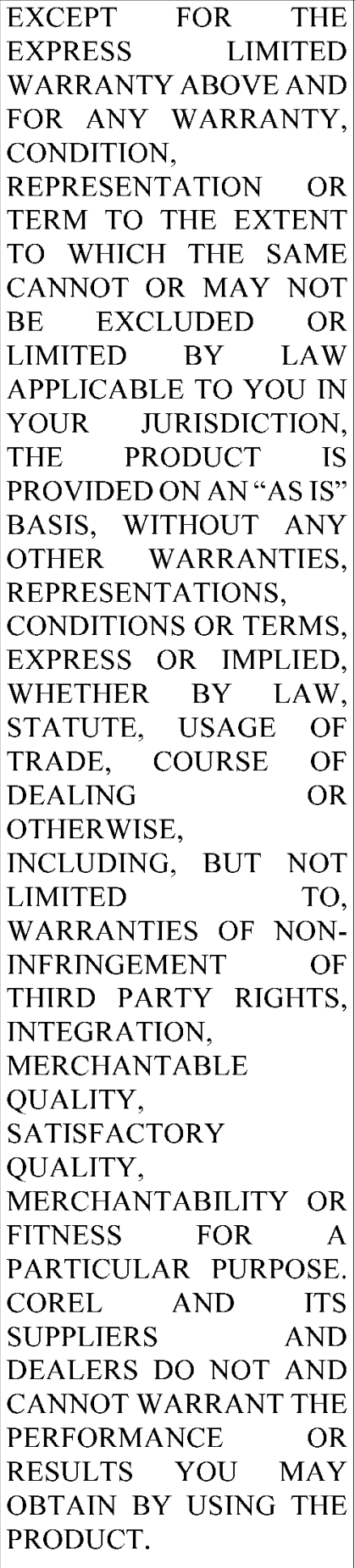 & 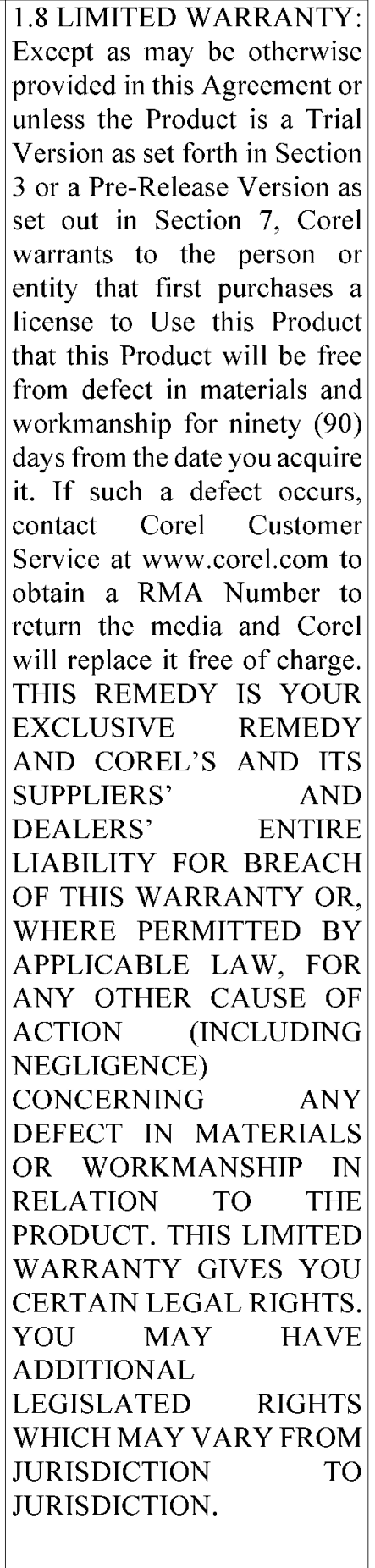 \\
\hline
\end{tabular}

